\title{
II Konferencja Otyłość Wieku Rozwojowego - od przyczyn do konsekwencji
}

W POSZUKIWANIU SKUTECZNYCH METOD TERAPEUTYCZNYCH

Katowice/Chorzów 12-13 października 2018 r.

STRESZCZENIA 
Streszczenia zostały wydrukowane w formie przesłanej przez autorów. 


\section{WARSZTATY}

\section{SESJA I: Wykłady plenarne Patronat: European Childhood Obesity Group (ECOG)}

\section{Od antropometrii do analizy składu ciała}

Paweł Matusik, Agnieszka Zachurzok

Katedra i Klinika Pediatrii i Endokrynologii Dziecięcej, Śląski Uniwersytet Medyczny w Katowicach

\section{Otyłe dziecko - problem rodziny, lekarza czy społeczeństwa?}

Obese child - a challenge for the family, physician or society?

Ewa Małecka-Tendera

Katedra i Klinika Pediatrii i Endokrynologii Dziecięcej, Śląski Uniwersytet Medyczny w Katowicach

Otyłość u dzieci i młodzieży jest narastającym problemem większości populacji i to nie tylko w krajach o wysokim stopniu rozwoju. W całej Ameryce Północnej ponad $15 \%$ dzieci ma nadwagę lub otyłość, a w niektórych stanach USA liczba ta oscyluje nawet w granicach $40 \%$. Jednak problem dotyczy także wielu krajów Afryki, w tym głównie RPA. Czy przyczyną tej epidemii są niewłaściwe relacje rodzinne, nieodpowiednia opieka lekarska czy też polityka ekonomiczna danego kraju? Kiedy powinno się rozpoczynać profilaktykę otyłości i które dzieci pozostają w grupie zwiększonego ryzyka?

Najbliższymi osobami w życiu dziecka są rodzice i dziadkowie, którzy powinni być świadomi zagrożeń wynikających z przekarmiania potomstwa. Wielu z nich wydaje się jednak całkowicie nie dostrzegać problemu, szczególnie gdy pozostali członkowie rodziny są otyli lub mają nadwagę. Rola lekarza jest więc często ograniczona do poinformowania rodziców o konieczności zmiany trybu życia i diety, co w większości rodzin napotyka na opór lub brak wiary w możliwość realizacji zaleceń.

Jeśli lekarz podejmuje się prowadzenia terapii otyłości u dziecka, konieczne jest przekonanie do współpracy całej rodziny. $U$ dziecka w wieku przedszkolnym zasadniczą rolę odgrywają jego opiekunowie, natomiast u starszych dzieci konieczna jest współpraca samego pacjenta. Brak chęci podjęcia leczenia niestety skazuje proces odchudzania na niepowodzenie. Dziewczęta w wieku dojrzewania często podejmują ryzykowne działania, spodziewając się szybkich i nierealnych efektów terapii. Chłopcy cierpią z powodu oszpecającej ich steatomastii lub relatywnie małych narządów płciowych ukrytych w podskórnej tkance tłuszczowej. U obu płci tworzące się rozstępy skórne są trwałym defektem wyglądu. Uczucie głodu jest jednak na tyle trudne do pokonania, że u większości pacjentów spadek masy ciała jest niewielki lub po okresie zmniejszenia otyłości następuje ponowny wzrost masy ciała. Bardzo wielu nastolatków w pewnym stopniu zaczyna akceptować swoją otyłość i szukać partnera z podob- 
nym problemem. Zasadniczym działaniem w zwalczaniu epidemii otyłości u dzieci powinna być jej prewencja, w której zasadnicza rola przypada społeczeństwu. Wiele krajów podejmuje działania mające na celu ograniczenie spożywania żywności typu fast food oraz opodatkowania producentów napojów wysokokalorycznych. W akcje włączają się także szkoły i przedszkola, propagując spożywanie przez dzieci jarzyn i owoców w miejsce słodkich przekąsek i picie wody zamiast słodkich gazowanych napojów. Działania te w niektórych społeczeństwach doprowadziły do zmniejszenia tempa narastania liczby otyłych dzieci lub zahamowania tej tendencji. Jesteśmy jednak jeszcze daleko od sukcesu i musimy się liczyć ze zwiększaniem się liczby pacjentów z powikłaniami otyłości, którzy będą wymagać kompleksowej i kosztownej opieki medycznej.

Childhood obesity is a growing problem for several societies, surprisingly not only for the well-developed ones. In North America over 15\% of children are obese or overweight, and in some USA states it exceeds $40 \%$. Moreover the problem concerns many African countries, with South Africa being on the top of the list. What is the background of this epidemics - disturbed family relations, impaired health service or wrong economic politics of the countries involved? When should the prevention of childhood obesity be started and which children remain in the high-risk group?

Parents and grandparents, who are the closest relatives of the child, should be the ones who are most aware of the negative consequences of the overfeeding of their offspring. However many of them seem to be totally ignorant with respect to this problem, particularly if they are obese or overweight themselves. Physician's role is therefore limited to drawing attention of the parents to the necessary action of changing their diet and increasing physical activity, to what advice many families are strongly reluctant or they do not believe in positive results of such efforts.Family doctor who undertakes the effort of obesity treatment should therefore convince the whole family that he needs their cooperation as such.

In a preschool child family plays the basic role in changing the diet and life-style but in older children their own cooperation is essential. Lack of understanding of the problem and reluctance of following the doctor's recommendations means that all he can expect is a failure. Obese teen-aged girls commonly try risky and potentially dangerous behaviors expecting quick and unrealistic results. Boys often suffer from disfiguring steatomastia or relatively small external genitalia hidden in the subcutaneous fat tissue. In both genders reddish skin striae are common and once they appear they are usually life-long. However the feeling of hunger is so hard to resist that in majority of patients the weight loss is not very significant or after a short time a relapse of overweight appears. Finally many teenagers starts to accept their obesity and seeks the partner with the similar problem.

Prevention is therefore the basic action in which the society should play the main role. Several countries undertake actions reducing fast-food consumption by children and putting high taxes on the manufacturers of soda drinks. Schools and kindergartens try to teach children how to replace the high calories snacks by fruit and vegetables and soda drinks with water. Some of the countries succeeded to decrease or stop the increase of obesity epidemics in the youngest children. However the whole world is far from the success in this field. Therefore we have to face the increasing problem of treating more patients with obesity complications that will need more financial support from the health service.

\section{Paediatric Obesity Epidemic - the European Perspective}

Daniel Weghuber

Department of Pediatrics, Paracelsus Medical University Salzburg, Austria 


\section{SESJA II: Zaburzenia hormonalne}

a otyłość dziecięca

Patronat: Polskie Towarzystwo Endokrynologii i Diabetologii Dziecięcej (PTEiDD)

\section{Hypothalamic Obesity (HyOb) in Children}

\section{Ze'ev Hochberg}

Technion - Israel Institute of Technology, Haifa, Israel

$\mathrm{HyOb}$ is a complex disease derived from damage to several hypothalamic nuclei that includes leptin resistance and hyperleptinemia, melanocortin deficiency and resistance due to MC4R damage, modulation of POMC and NPY, oxytocin and CRH, finally affecting food intake and weight gain. At the end-organ targets, $\mathrm{HyOb}$ leads to enhanced $11 \beta$-hydroxysteroid dehydrogenase- 1 activity, a decrease in sympathetic tone and increases in vagal tone, resulting in insulin hypersecretion. Attempts to ameliorate only one of these agents have been used for limited periods in a small number of patients with limited success.

Conclusion: The complexity of $\mathrm{HyOb}$ requires a strategy, probably multi-drug, of simultaneous targeting as many as possible of these mechanisms, adjuncts to behavioral and lifestyle changes.

\section{Endokrynopatie a otyłość w wieku rozwojowym - przyczyna czy skutek?}

\section{Endocrinopathies and childhood obesity - cause or result?}

Piotr Fichna, Bogda Skowrońska

Klinika Diabetologii i Otyłości Wieku Rozwojowego,

Uniwersytet Medyczny im. Karola Marcinkowskiego w Poznaniu

Otyłość może być następstwem zaburzeń w układzie dokrewnym, najczęściej jednak jest ona wtórna do hiperalimentacji i ograniczonego wydatku energetycznego. Prowadzi to do zmiany czynności dokrewnej tkanki tłuszczowej, innej jej interakcji z pozostałymi gruczołami układu dokrewnego, a także do zmiany wrażliwości różnych komórek docelowych organizmu na działanie hormonów.

Od połowy lat 90. bardzo intensywnie zmienia się wiedza o funkcji tkanki tłuszczowej, która jest nie tylko depozytem substratu energetycznego, ochroną mechaniczną, izolatorem termicznym, lecz także rozsianym $\mathrm{w}$ organizmie narządem o bardzo intensywnym metabolizmie, który wchodzi w interakcje czynnościowe z wielo- ma narządami, np. wątrobą, mięśniami, gruczołami dokrewnymi wielu osi hormonalnych. Pośrednikami w jej funkcji dokrewnej są tzw. adipokiny, z których część ma działanie hormonalne, inne prozapalne w samej tkance tłuszczowej oraz w oddziaływaniu na inne narządy.

Zaburzenia hormonalne spostrzegane u dzieci i młodzieży z otyłością dotyczą praktycznie wszystkich osi: wzrostowej, tarczycowej, nadnerczowej i gonadalnej. Obserwowane zaburzenia mają przeważnie charakter wtórny do nadmiaru tłuszczowej masy ciała.

Terapię należy w pierwszej kolejności rozpocząć od leczenia pierwotnej patologii, jaką jest otyłość. Wsparcie farmakologiczne musi być bardzo wyważone, niekiedy zastosowane tylko czasowo i obok, nigdy zamiast, zasadniczej terapii otyłości. Takie postępowanie, prowadzące do poprawy proporcji masy ciała do wzrostu, w większości przypadków prowadzi także do przywrócenia prawidłowej równowagi hormonalnej u dzieci z otyłością.

Obesity may be a result of endocrine system disorders, but mostly it is secondary to hyperalimentation and limited energy expenditure. This leads to a change in the activity and interaction of adipose tissue with the endocrine system.

Since the mid-90s one observed intensively changing knowledge about the function of adipose tissue, which is not only a deposit of energy, mechanical protection, thermal insulator, but also disseminated in the body organ with a very intense metabolism, which interacts with many organs, e.g. liver, muscles, endocrine glands. Adipokines, produced by fat tissue, could have not only hormonal effects, but also proinflammatory in the adipose tissue itself or in other organs.

Hormonal disorders observed in children and adolescents with obesity concern practically all axes: growth, thyroid, adrenal and gonadal. The observed disorders are usually secondary to excessive body fat mass. Therapy should first be started with the treatment of primary pathology, which is obesity. Pharmacological support needs to be very balanced, sometimes only applied temporarily and next to, never in the first place, obesity therapy. Such a procedure, leading to an improvement in the proportion of body weight to growth, in most cases also leads to the restoration of normal hormonal balance in children with obesity. 


\section{Otyłość jako narastający problem u dzieci z cukrzycą typu 1}

\author{
Obesity as an increasing problem in children with \\ type 1 diabetes
}

\section{Barbara Głowińska-Olszewska}

Klinika Pediatrii, Endokrynologii, Diabetologii z Pododdziałem Kardiologii, Uniwersytet Medyczny w Białymstoku

Nadwaga i otyłość coraz częściej współwystępują z cukrzycą typu 1 u dzieci i młodzieży. Szacuje się, że nawet do $35 \%$ młodych pacjentów $z$ tym typem cukrzycy, do niedawna uważanym za charakterystyczny dla szczupłej sylwetki ciała, ma nadmiar masy ciała. Ogólny wzrost częstości otyłości w populacji dziecięcej komplikuje różnicowanie typu cukrzycy u małego pacjenta. Współwystępowanie otyłości ma znaczenie na każdym etapie rozwoju cukrzycy typu 1. Potwierdzono znaczenie dla ryzyka rozwoju choroby oraz wpływ na ujawnienie się cukrzycy w młodszym wieku u osób predysponowanych. Znaczna część dzieci z otyłością i cukrzycą ma dodatkowe czynniki ryzyka rozwoju makroangiopatii i rozpoznawany jest u nich zespół metaboliczny, insulinooporność oraz choroby typowe dla cukrzycy typu 2, takie jak zespół policystycznych jajników czy niealkoholowe stłuszczeniowe zapalenie wątroby. Częstość otyłości wzrasta szczególnie w okresie dojrzewania, u płci żeńskiej ma istotny, negatywny wpływ na wyrównanie metaboliczne choroby zasadniczej, wahania glikemii i zapotrzebowanie na insulinę. Ryzyko rozwoju powiań mikroangiopatycznych również dodatkowo istotnie wzrasta. Postępowanie terapeutyczne jest złożone i obejmuje, obok insulinoterapii i leczenia niefarmakologicznego, próby leczenia insulinooporności za pomocą pochodnych biguanidów, lekami typowymi dla cukrzycy typu 2, takimi jak analogi GLP-1, inhibitory receptora SGLT-2, czy nawet za pomocą chirurgii bariatrycznej.

The prevalence of overweight and obesity in youth patients with diabetes type 1 is increasing. It is estimated, that even up to $35 \%$ of young patients with this type of diabetes, considered so far to be characteristic for slim figure, are overweight. General increase of obesity in children's population compliates differnetial diagnosis of the type of diabetes in youths. Coexistence of obesity has clinical implications in all stages of diabetes course. It is confirmed, that obesitry is the risk factor for autpoimmune diabetes, and is connected with the earlier onset of diabetes in predisposed patients. Many diabetic patiens with obesity present additional risk factors for macroangipathy, and are recognised to present metabolic syndrome, insulin resitance, and typical for diabetes type 2 - policystic ovary syndrome, or non-alcoholic fatty liver disease. The prevalence of obesity increases dramatically in adoles- cence of diabetic child, more often in girls. It has negative impact to metabolic control, glycaemic variability and insulin demand. Risk for microangipatic complications increase as well. The treatment is difficult and includes not only insulinotherapy and non-pharmacological trials. Recently treatment of insulin resistance with biguanids, and treatment with typical for type 2 new diabetes drugs like GLP-1 analogs, SGLT-2 receptor inhibitors, or even cases or bariatric surgery also has been reported.

\section{Ryzyko utrwalenia otyłości dziecięcej i jej powikłań w wieku dorosłym w świetle najnowszych danych}

\author{
The risk of consolidation of children's obesity and its \\ complications in adult life in the light of the latest data \\ Jerzy Starzyk \\ Klinika Endokrynologii Dzieci i Młodzieży, Katedra Pediatrii, \\ Instytut Pediatrii, Collegium Medicum Wydziału Lekarskiego, \\ Uniwersytet Jagielloński w Krakowie
}

Wstęp: W opinii grupy roboczej EASO otyłość jest chorobą przewlekłą. Nadwaga i otyłość dotyczy w Europie $20-50 \%$ dzieci i jest przyczyną rozwoju u nich powikłań metabolicznych. Konsekwencje przetrwania otyłości i jej powikłań do okresu dorosłości są mniej poznane.

Materiał i metody: Krytycznej analizie poddano wyniki wieloośrodkowych badań i metaanaliz dotyczących tematu wykładu opublikowane w okresie ostatnich 20 lat.

Wyniki: Badania przekrojowe u 8579 dzieci (Skinner i wsp., 2015) wykazały, że czynniki ryzyka rozwoju chorób sercowo-naczyniowych (CVD), tj. nadciśnienie i zaburzenia metabolizmu lipidów i glukozy, występują u dzieci każdym wieku i są częstsze w cięższej otyłości. Z badań autopsyjnych (Berenson i wsp., 1998) wiadomo, że są one przyczyną rozwoju miażdżycy u otyłych nastolatków i młodych dorosłych. Badania obserwacyjne u 2,3 mln nastolatków (Twig i wsp., 2016) wykazały, że wraz ze wzrostem w tym wieku BMI wzrasta odsetek skumulowanej śmiertelności z powodu CVD w wieku dorosłym. Brak pomiaru BMI w wieku dorosłym nie pozwalał jednak wykluczyć, że jest to wynikiem otyłości przetrwałej do okresu dorosłości. Metaanaliza 4 badań u 6328 dzieci (Juanola i wsp., 2011) wykazała, że względne ryzyko (RR) rozwoju CVD w wieku dorosłym stanowi otyłość dziecięca przetrwała do okresu dorosłości $(1,7)$, a nie stanowi go otyłość, która ustąpi do tego okresu $(0,88)$. Brak w badaniu podziału na grupy wiekowe dzieci i nastolatków uniemożliwia odpowiedź na pytanie, czy zwiększone RR jest wynikiem przetrwania do okresu dorosłości otyłości młodzieżowej czy rozwijającej się wcześniej. Badania kohortowe u 11500 dzieci (Park i wsp., 2013) wykazały naj- 
większy iloraz szans rozwoju CVD w otyłości trwającej przez cały okres dziecięco-młodzieżowy i przetrwałej do dorosłości (6,62 dla przewlekłej choroby serca i 12,6 dla cukrzycy typu 2), znacznie większy niż wynikający z otyłości tylko w okresie dorosłości (odpowiednio 3,8 i 5,5) i najmniejszy dla otyłości w całym okresie rozwojowym bez kontynuacji w okresie dorosłości (odpowiednio 3,4 i 1,24). Dane dotyczące czynników ryzyka pochodziły jednak z badań ankietowych.

Wnioski: Powikłania kardiometaboliczne otyłości rozwijają się już u dzieci, zwłaszcza w okresie dojrzewania. Otyłość okresu dziecięco-młodzieżowego przetrwała do okresu dorosłości stanowi około 2-krotnie większe ryzyko zgonów z powodu CVD u młodych dorosłych niż otyłość ograniczona tylko do okresu dorosłości. Ryzyko to dla otyłości okresu rozwojowego nieprzetrwałej do dorosłości jest najmniejsze. W profilaktyce CVD i śmiertelności u młodych dorosłych decydujące znaczenie ma profilaktyka i leczenie otyłości u dzieci.

Introduction: In the opinion of the Childhood Obesity Task Force of EASO obesity is a chronic disease. Overweight and obesity affect $20-50 \%$ of European children and result in their metabolic sequels. The risk of obesity and its complications persisting till adulthood are less known.

Material and methods: The results of multicenter researches and metaanalysis published in the last 20 years refering to the topic of the lecture have been subjected to critical analysis.

Results: Cross-sectional study in a group of 8579 children (Skinner et al., 2015) showed that metabolic risk factors of the cardiovascular disease (CVD) e.g. hypertension and disorders of lipids and glucose metabolism occur in children of all ages with higher prevalence in more severe obesity. From autopsy studies (Berenson et $a l ., 1998)$ it is known that these risk factors are responsible for atherosclerosis development in obese adolescents and in young adults. Observational study in $2.3 \mathrm{mln}$ teenagers (Twig et al., 2016) showed that with their increasing BMI in adolescent period cumulative mortality from CVD in early adulthood also increases. Lack of the BMI data in adulthood did not let exclude that these complications result from adolescent obesity persisting till adulthood. Metaanalysis of 4 studies in 6328 children (Juanola et al., 2011) found that the relative risk (RR) of CVD in adults results from persisting childhood obesity (1.7) and is not increased in obesity which ceased before adulthood (0.88). The lack of division into age groups between children and teenagers disallows to answer the question whether increased RR results from persistence of adolescence obesity or from the one developed earlier. Cohort study in 11500 children (Park et al., 2013) showed the highest odds ratio of CVD in obesity persisting through- out childhood and adolescence period till adulthood (6.62 for chronic heart disease and 12.6 for diabetes mellitus type 2), markedly higher than resulting from obesity restricted to adulthood period (3.8 and 5.5 respectively), and the lowest for whole childhood-adolescence obesity without continuity in adulthood (3.4 and 1.24 respectively). The data regarding these risk factors came, however, from a survey research.

Conclusions: Cardiometabolic sequels of obesity develop already in children, especially in adolescence period. Obesity persisting throughout childhood and adolescence periods till adulthood results in approx. twice higher relative risk of death due to CVD in young adults than obesity restricted to adulthood only. The risk of childhood and adolescent obesity without continuity in adulthood is the lowest. Prevention or treatment of obesity in children is crucial in the prevention of CVD and mortality in early adulthood.

\section{Czy rekombinowany hormon wzrostu jest „lekiem na całe zło" w zespole Pradera i Williego?}

\section{Is recombinant growth hormone "a cure to all evil" in Prader-Willi syndrome?}

\section{Barbara Kalina-Faska ${ }^{1}$, Maria Kalina²}

${ }^{1}$ Katedra i Klinika Pediatrii i Endokrynologii Dziecięcej, Wydział Lekarski w Katowicach, Śląski Uniwersytet Medyczny w Katowicach 2Zakład Genetyki Klinicznej Katedry Biologii Molekularnej i Genetyki, Wydział Lekarski w Katowicach, Śląski Uniwersytet Medyczny w Katowicach

Zespół Pradera i Williego (PWS) jest genetycznie uwarunkowanym zaburzeniem związanym z piętnowaniem genomowym, wynikającym $\mathrm{z}$ utraty ekspresji genów w regionie 15q11.2-q13 na allelu ojcowskim. Częstość występowania PWS szacuje się na 1:10 000 - 30000 urodzeń. Zespół charakteryzuje się hipotonią mięśniową, specyficznymi cechami dysmorfii i szeregiem zaburzeń wynikających głównie z dysfunkcji podwzgórza. Pacjenci z PWS odznaczają się brakiem uczucia sytości i niższym spoczynkowym wydatkiem energetycznym (REE). Po okresie słabego przyrostu masy ciała $\mathrm{w}$ niemowlęctwie następuje hiperfagia i otyłość, a w konsekwencji - zaburzenia metaboliczne.

U większości pacjentów z PWS występuje niedobór hormonu wzrostu (GH) i obniżone stężenie insulinopodobnego czynnika wzrostowego (IGF-1). Przesłanki stojące za stosowaniem rekombinowanego hormonu wzrostu (rGH) to nie tylko normalizacja wzrostu końcowego, lecz przede wszystkim poprawa proporcji ciała i korzystny wpływ na procesy metaboliczne. Zmniejszając ilość tkanki tłuszczowej, stymulując przyrost masy mięśniowej 
i zwiększając napięcie mięśniowe, $\mathrm{rGH}$ poprawia motorykę dzieci z PWS. Obserwuje się poprawę wskaźnika REE. Zapotrzebowanie energetyczne dziecka z PWS wynosi do 50\% normy dla dziecka zdrowego, w trakcie terapii rGH wzrasta ono do $75 \%$. Poprawia się funkcjonowanie mięśni oddechowych, zmniejsza się liczba bezdechów sennych. Wszystko to wpływa na wzrost aktywności, siły fizycznej oraz poprawę koordynacji ruchowej i jakości życia. Należy jednak podkreślić, że otyłość jest jednym z przeciwwskazań do podawania $\mathrm{rGH}$. Dlatego istotne jest wczesne rozpoczęcie terapii $\mathrm{rGH}$, nawet w okresie niemowlęcym, co zmniejsza ryzyko rozwoju otyłości i przyspiesza rozwój motoryczny. Natomiast w przypadku otyłych dzieci z PWS konieczna jest redukcja masy ciała przed włączeniem rGH, a w trakcie terapii - ścisła kontrola BMI. Poza tym hiperglikemizujące działanie rGH i zmniejszenie insulinowrażliwości obserwowano u dzieci z PWS, szczególnie z przyrostem BMI. W Polsce rGH jest lekiem refundowanym dla dzieci z PWS, z możliwością kontynuacji terapii w wieku dorosłym, pod warunkiem prawidłowego BMI. Hormon wzrostu nie zniweluje innych zaburzeń regulacji podwzgórzowej, w tym braku uczucia sytości i zachowań ukierunkowanych na poszukiwanie jedzenia. Tak więc terapia rGH jest bezcelowa bez równoległej ścisłej diety, aktywności ruchowej, rehabilitacji i terapii zajęciowej. Podejmowane są również próby włączenia wspomagająco innych farmakoterapii, m.in. oksytocyny, agonistów GLP-1 czy metforminy. Należy monitorować inne endokrynopatie. Wyzwaniem pozostają zaburzenia zachowania, niepełnosprawność intelektualna oraz aspekty związane z seksualnością. Nadzieją na leczenie przyczynowe w PWS są próby in vitro odwrócenia piętnowania genomowego.

Prader-Willi syndrome (PWS) is a genetic disorder, connected with the phenomenon of genomic imprinting and lack of expression of genes in the region 15q11.2-q13 on the paternal allele. The estimated prevalence of PWS is 1 in 10000 to 30000 . It is characterized by hypotonia, specific dysmorphic features and spectrum of disturbances, mainly due to hypothalamic dysfunction. Patients with PWS present with lack of satiety and decreased resting energy expenditure (REE). The period of failure to thrive in infancy is followed by hyperphagia and obesity and subsequent metabolic disturbances.

Most patients with PWS show growth hormone $(\mathrm{GH})$ deficiency and low concentrations of insulin-like growth factor (IGF-1). Basis for recombinant growth hormone $(\mathrm{rGH})$ therapy includes normalization of the final height, but most importantly improvement of body proportions and beneficial effects on metabolic processes. By ddecreasing adipose tissue content, stimulating muscle growth and increasing muscle tone, rGH contributes to motor improvement of children with PWS. Energy requirement in children with PWS is up to $50 \%$ of the norm for a healthy child. It increases to $75 \%$ during rGH therapy, with improvement of REE index. Functioning of respiratory muscles is enhanced, the number of apnea decreases. All these phenomena contribute to increased activity, physical strength and improvement of motor coordination and quality of life. It has to be underlined though, that obesity is one of contraindications for $\mathrm{rGH}$ therapy. Thus it is crucial to start rGh therapy early, even in the infancy, decreasing risk of obesity and accelerating motor development. In case of obese children with PWS it is necessary to lose weight prior to $\mathrm{rGH}$ treatment, and during therapy - to control BMI strictly. Besides, hyperglycemic effect of rGH and reduced insulin sensitivity were observed particularly in PWS children with increasing BMI. In Poland $\mathrm{rGH}$ is reimbursed for children with PWS, with possibility to continue therapy in adulthood, providing normal BMI. Growth hormone will not eliminate other hypothalamic disturbances, including lack of satiety and behaviors directed at seeking food. Thus, rGH therapy is futile without parallel strict diet, physical activity, physiotherapy and occupational therapy. There are also attempts to use other adjuvant therapies, including oxytocin, GLP1 agonists, metformin. Other endocrinopathies have to be monitored. Behavioral problems, intellectual disability or aspects connected with sexuality constitute other challenges. Trials in vitro to reverse genomic imprinting may be a promising option for causative treatment of PWS.

\section{Leptyna i jej bioaktywność u dzieci z otyłością o wczesnym początku - badanie niemiecko-polskie (EOL-GPS)}

\section{Leptin and its bioactivity in children with severe early- onset obesity - the German-Polish Study (EOL-GPS)}

Agnieszka Zachurzok ${ }^{1}$, Ewa Małecka-Tendera ${ }^{1}$, Elżbieta Petriczko², Artur Mazur ${ }^{3}$, Lutz Pridzun ${ }^{4}$, Bertram Flehmig ${ }^{4}$, Julia von Schnurbein ${ }^{5}$, Michael B. Ranke ${ }^{6}$, Martin Wabitsch ${ }^{5}$, Stephanie Brandt ${ }^{5}$, Katarzyna Marcinkiewicz ${ }^{2}$

${ }^{1}$ Klinika Pediatrii i Endokrynologii Dziecięcej, Śląski Uniwersytet Medyczny w Katowicach, Polska

${ }^{2}$ Klinika Pediatrii, Endokrynologii i Diabetologii, Pomorski

Uniwersytet Medyczny w Szczecinie, Polska

${ }^{3}$ Klinika Pediatrii, Wydział Medyczny, Uniwersytet Rzeszowki, Polska

${ }^{4}$ Mediagost GmbH, Reutlingen, Niemcy

${ }^{5}$ Department of Pediatrics and Adolescent Medicine, Division of Pediatric Endocrinology and Diabetes, Center for Rare Endocrine Diseases, Ulm, Niemcy

${ }^{6}$ University Children's Hospital, Tübingen, Niemcy

Wstęp: U dzieci z otyłością olbrzymią o wczesnym początku istnieje zwiększone prawdopodobieństwo jej podłoża genetycznego. Dlatego też w postępowaniu dia- 
gnostycznym należy wziąć pod uwagę mutacje w genie leptyny i jej receptora. Dotychczas stwierdzono mutacje w genie leptyny, które prowadzą do jej bezwzględnego niedoboru w surowicy krwi. W ostatnich latach u osób $\mathrm{z}$ fenotypem typowym dla niedoboru leptyny i wysokim jej stężeniem w surowicy krwi zdiagnozowano mutacje w jej genie powodujące brak biologicznej aktywności hormonu. Takie osoby, podobnie jak pacjenci $\mathrm{z}$ bezwzględnym niedoborem leptyny, mogą być leczone rekombinowaną ludzką leptyną (metreleptyna).

Cel: Celem pracy była ocena antropometryczna oraz zbadanie parametrów szlaku leptyny, szczególnie w poszukiwaniu biologicznie nieaktywnej formy hormonu, u dzieci z otyłością olbrzymią o wczesnym początku.

Materiał i metody: Do badania włączono dzieci, u których BMI przed 6. rokiem życia przekraczało $25 \mathrm{~kg} /$ $\mathrm{m}^{2}$, będące pacjentami czterech ośrodków medycznych (Niemcy: $n=1$, Polska: $n=3$ - Niemiecko-Polskie Konsorcjum, EOL-GPS) pomiędzy lipcem 2015 i grudniem 2017 r. U wszystkich dzieci oraz dostępnych rodziców dokonano pomiarów antropometrycznych [waga $(\mathrm{kg})$, wzrost $(\mathrm{cm})$, BMI $\left.\left(\mathrm{kg} / \mathrm{m}^{2}\right)\right]$ oraz pobrano próbki krwi do badań laboratoryjnych. Oznaczono stężenie leptyny całkowitej (totLEP), bioaktywnej (bioLEP) oraz rozpuszczalnej formy receptora leptyny (sLEPR). Obliczono stosunek stężeń bioLEP/totLEP oraz LEP-SDS.

Wyniki: Analizie statystycznej poddano dane 50 dzieci (dziewczynki: $56 \%$, 1. st. wg Tannera: $85,7 \%$, wiek: 7,7 \pm 4,5 roku, BMI: $32,2 \pm 9,3 \mathrm{~kg} / \mathrm{m}^{2}$; BMI-SDS: $3,7 \pm 0,9$; \%BMIP95: 157,3 \pm 30,7\%) oraz 45 matek i 43 ojców (42 triady - dziecko + oboje rodzice). U żadnego z badanych dzieci nie stwierdzono niedoboru leptyny lub jej nieaktywnej formy. Stężenie totLEP u dzieci wynosiło pomiędzy 25,2 a 49,2 ng/ml (zakres międzykwartylowy). Stwierdzono istotną dodatnią korelację pomiędzy stężeniem totLEP a BMI $(r=0,68 ; p<0,05)$ oraz negatywną $\mathrm{z}$ sLEPR $(r=-0,39 ; p<0,05)$. Ponadto stężenie sLEPR korelowało negatywnie $\mathrm{z}$ wiekiem $(r=-0,53$; $p<0,05)$ i BMI $(r=$ $-0,44, p<0,05)$, a LEP-SDS z BMI $(r=-0,70 ; p<0,05)$ U 80\% rodziców stwierdzono nadwagę lub otyłość.

Wnioski: W badanej przez nas grupie nie stwierdzono dzieci z niedoborem leptyny lub jej bioaktywnej formy. Badania potwierdzają negatywną zależność pomiędzy sLEPR a wiekiem i BMI dzieci. Natomiast silna negatywna korelacja pomiędzy LEP-SDS a BMI może być interpretowana jako względny niedobór leptyny. Istnienie odmiennych zależności pomiędzy parametrami szlaku leptyny i BMI u dzieci z otyłością o wczesnym począt$\mathrm{ku}$ i u dzieci z prawidłową masą ciała wymaga dalszych badań i potwierdzenia na większej liczbie pacjentów.

Introduction: Severe early-onset obesity (SEOO) is more likely to be caused by genetic factors which those of leptin pathway should be consider in the diagnostic ap- proach of severe obese young child. In humans mutations in leptin gene leading to low serum leptin concentration as well leptin receptor mutation were described. In recent years in severely obese children with high serum leptin level, mutation in leptin gene was found, resulting in biologically inactive hormone production. These individuals, as the patient with leptin deficiency, can benefit from recombinant human leptin (metreleptin) treatment.

Objective: The aim of the study was to investigate anthropometrics and leptin pathway parameters, specifically searching for bio-inactive leptin, in children with SEOO.

Material and methods: Study cohort includes children who developed a BMI $>25 \mathrm{~kg} / \mathrm{m}^{2}$ before an age of 6 years and who were presented at individual study centers (Germany: $n=1$, Poland: $n=3$ - German-Polish consortium, EOL-GPS) between July 2015 and December 2017. Anthropometric parameters (weight [kg], height $[\mathrm{cm}]$, BMI $\left[\mathrm{kg} / \mathrm{m}^{2}\right]$ ) were measured and a serum blood sample was taken. If possible, parental anthropometric parameters (weight $[\mathrm{kg}]$, height $[\mathrm{cm}], \mathrm{BMI}\left[\mathrm{kg} / \mathrm{m}^{2}\right]$ ) and blood samples were ascertained. Levels of total leptin (totLEP), bio-active leptin (bioLEP) and soluble leptin receptor (sLEPR) were measured in serum samples. Quotient of bioLEP/totLEP and LEP-SDS were calculated.

Results: Data of $n=50$ children (female: $56 \%$, Tanner stage 1: $85.7 \%$, age at blood sampling: $7.7 \pm 4.5$ years, BMI: $32.2 \pm 9.3 \mathrm{~kg} / \mathrm{m}^{2}$; BMI-SDS: $3.7 \pm 0.9$; \%BMIP95: $157.3 \pm 30.7 \%)$, of $n=45$ mothers and $n=43$ fathers $(n=$ 42 trios) were included in statistical analysis. We identified no child with leptin deficiency or bio-inactive leptin. Measured totLEP concentrations in children ranged between 25.2 and $49.2 \mathrm{ng} / \mathrm{ml}$ (interquartile range). Within correlation analyses between leptin parameters and anthropometrics in children, we observed that: totLEP concentrations were positively correlated with BMI $(r=0.68$, $p<0.05)$ and negatively correlated with $\operatorname{sLEPR}(r=-0.39$, $p<0.05)$; sLEPR levels were negatively correlated with age $(r=-0.53, p<0.05)$ and BMI $(r=-0.44, p<0.05)$; LEP-SDS were negatively correlated with BMI $(r=-0.70$, $p<0.05)$. Analysis of trios identified that $80 \%$ of parents were overweight/obese.

Conclusions: In our cohort with SEOO we identified no new cases of children with leptin deficiency or bio-inactive leptin. We confirmed previously published observations of negative associations between SLEPR, age and BMI in children. The strong negative correlation between LEP-SDS and BMI values could be interpreted as relative leptin deficiency. However further collection and analysis of severely early-onset obese children must prove whether the relationship between BMI and leptin parameters is definitely different from normally weighing children. 


\section{SESJA III: Składowe zespołu} metabolicznego - od diagnozy do terapii

Patronat: Polskie Towarzystwo Lipidologiczne (PoLA)

\section{Nadciśnienie tętnicze u dzieci otyłych - postępowanie diagnostyczne i terapeutyczne}

\section{Hypertension in obese children - diagnostics and therapy}

\section{Dorota Drożdż}

Klinika Nefrologii Dziecięcej, Uniwersytet Jagielloński Collegium Medicum w Krakowie

Oddział Nefrologii i Nadciśnienia Tętniczego, Uniwersytecki Szpital Dziecięcy w Krakowie

Nadmiar tkanki tłuszczowej wiąże się ze zwiększoną częstością występowania czynników ryzyka sercowo-naczyniowego: nadciśnienia tętniczego, dyslipidemii, zaburzeń gospodarki węglowodanowej oraz dysfunkcji i zmian strukturalnych mięśnia sercowego, a także innych powikłań. Ze wzrostem BMI rośnie ryzyko rozwoju nadciśnienia tętniczego (NT). Do patomechanizmów wzrostu ciśnienia tętniczego krwi w otyłości zalicza się aktywację układu renina-angiotensyna-aldosteron i układu sympatykomimetycznego, retencję wody i sodu, hiperinsulinizm i insulinooporność, dysfunkcję śródbłonka, przewlekły proces zapalny i stres oksydacyjny.

U młodszych dzieci z otyłością NT należy diagnozować na podstawie pomiarów gabinetowych na 3 niezależnych wizytach, natomiast od 6. roku życia preferowaną metodą jest 24-godzinna rejestracja ciśnienia tętniczego krwi (ambulatory blood pressure monitoring - ABPM).

U dziecka z potwierdzonym NT wykonuje się podstawowe badania biochemiczne z oceną czynników ryzyka sercowo-naczyniowego oraz uszkodzeń narządowych. U pacjentów $z$ BMI > 85. centyla oprócz glikemii zalecany jest test obciążenia glukozą i pomiar stężenia insuliny na czczo. W wybranych przypadkach wskazane jest wykonanie polisomnografii.

Postępowanie terapeutyczne $\mathrm{u}$ dzieci z NT 1. stopnia rozpoczynamy od leczenia niefarmakologicznego. Uszkodzenia narządowe nadciśnienia tętniczego w postaci przerostu lewej komory serca, 2. stopień NT lub nieskuteczność modyfikacji stylu życia jest wskazaniem do leczenia farmakologicznego. W leczeniu nadciśnienia tętniczego u pacjentów $\mathrm{z}$ otyłością zalecane jest stosowanie inhibitorów konwertazy angiotensyny lub blokerów receptora angiotensyny oraz blokerów kanału wapniowego. Należy unikać leków nasilających zaburzenia metabo- liczne (diuretyki tiazydowe, $\beta$-blokery). Współwystępowanie otyłości i nadciśnienia tętniczego zwiększa ryzyko powikłań sercowo-naczyniowych w wieku dorosłym.

W ramach prewencji nadwagi i otyłości konieczne jest opracowanie kompleksowych programów obejmujących działania dietetyczne i wysiłek fizyczny.

Pacjenci z nadwagą i otyłością powinni być objęci wielospecjalistyczną opieką $\mathrm{w}$ ramach specjalnych poradni i oddziałów.

Excess adipose tissue is associated with an increased incidence of cardiovascular risk factors: hypertension, dyslipidemia, carbohydrate metabolism disorders and dysfunction and structural changes in the myocardium, as well as other complications. With the increase in BMI, the risk of developing hypertension (HTN) increases. Pathomechanisms of increased blood pressure in obesity include activation of the renin-angiotensin-aldosterone system and the sympathomimetic system, water and sodium retention, hyperinsulinism and insulin resistance, endothelial dysfunction, chronic inflammation and oxidative stress.

In younger children with obesity hypertension should be diagnosed on the basis of office measurements on 3 independent visits, while from the age of 6 the preferred method is 24-hour registration of blood pressure (ABPM - ambulatory blood pressure monitoring).

In children with confirmed HTN basic biochemical tests with the assessment of cardiovascular risk factors and organ damage are carried out. In patients with BMI above $85^{\text {th }}$ percentile, in addition to glucose, an oral glucose tolerance test and measurement of fasting insulin are recommended. In selected cases, it is advisable to perform polysomnography.

Therapy in children with stage 1 HTN begins with non-pharmacological treatment. Hypertension organ damage in the form of left ventricular hypertrophy, stage 2 HTN or ineffectiveness of lifestyle modification are indicators for pharmacological treatment. In the treatment of hypertension in obese patients it is recommended to use angiotensin converting enzyme inhibitors or angiotensin receptor blockers and calcium channel blockers. Drugs that increase metabolic disturbances (thiazide diuretics, $\beta$-blockers) should be avoided. Co-morbidity of obesity and hypertension increases the risk of cardiovascular complications in adulthood.

In prevention of overweight and obesity it is necessary to develop comprehensive programs including diet and physical activity.

Patients with overweight and obesity should be under multidisciplinary care within dedicated outpatient clinics and departments. 


\section{Od insulinooporności do cukrzycy typu 2}

\section{From insulin resistance to type 2 diabetes mellitus \\ Grażyna Deja \\ Klinika Diabetologii Dziecięcej, Śląski Uniwersytet Medyczny w Katowicach}

Obserwowany w ostatnich dekadach wzrost nadwagi i otyłości wśród dzieci prowadzi do powstania wielu zaburzeń metabolicznych, w tym także zaburzeń homeostazy glukozy. W etiopatogenezie cukrzycy typu 2, będącej efektem końcowym tych zaburzeń, kluczową rolę odgrywa obniżenie wrażliwości na insulinę tkanek obwodowych zwane insulinoopornością. Istnieje wiele metod badania insulinowrażliwości, które stosowane są zarówno do celów naukowych, jak i diagnostycznych. Metody bezpośrednie, takie jak: metoda klamry metabolicznej, dożylny test tolerancji glukozy, dożylny test tolerancji insuliny czy test supresji insuliny endogennej, wykorzystywane są głównie do celów naukowych. W praktyce klinicznej, w badaniach populacyjnych, stosuje się raczej metody pośrednie oceniające relację pomiędzy stężeniem insuliny i glukozy na czczo lub w czasie testu OGTT. Zazwyczaj istotnym objawem sugerującym występowanie insulinooporności jest stwierdzane $\mathrm{w}$ badaniu fizykalnym rogowacenie ciemne.

Oceniając przydatność stosowania metod do oceny insulinowrażliwości u dzieci, uzyskuje się dużo bardziej zróżnicowane wyniki niż u dorosłych. Istotnym problemem diagnostycznym w jednoznacznej ocenie insulinooporności wciąż pozostaje duża zmienność pulsacyjnie wydzielanej insuliny - z tego powodu zaleca się kilkukrotne oznaczanie insulinemii i stosowanie wartości średniej. Kolejnym problemem w populacji pediatrycznej jest brak szeroko uznawanych norm dla różnych populacji czy ras. W krajach europejskich, w tym w Polsce, cukrzyca typu 2 wciąż występuje stosunkowo rzadko, choć także obserwuje się wzrost częstości zachorowań. Problemem coraz bardziej alarmującym staje się wyraźnie zauważalny wzrost liczby dzieci z nieprawidłowymi wynikami testu OGTT w zakresie wydzielania insuliny.

Mechanizmy prowadzace do całkowitej dysfunkcji komórek B w zakresie kontroli glikemii i pełnego rozwoju cukrzycy typu 2 są skomplikowane, zazwyczaj proces ten wymaga dłuższego czasu. Stwarza to realne szanse na zatrzymanie zaburzeń kontroli glikemii na etapie otyłości $\mathrm{z}$ insulinoopornością lub okresu prediabetes. Aktualnie prowadzone są badania dotyczące możliwości odwrócenia tych zaburzeń, od lat klasycznie stosuje się w tym celu różne preparaty metforminy. Wciąż jednak podstawowym problemem pozostaje konieczność wprowadzenia stałych zmian dotyczących sposobu odżywiania i stylu życia.
The increase in overweight and obesity among children observed in recent decades leads to the occurrence of many metabolic disorders, including glucose homeostasis disorders. In the etiopathogenesis of type 2 diabetes, which is the end result of those disorders, the reduction of insulin sensitivity of peripheral tissues called insulin resistance plays a key role. There are many methods of insulin sensitivity testing that are used for both scientific and diagnostic purposes. Direct methods such as the metabolic clamp method, intravenous glucose tolerance test, intravenous insulin tolerance test or endogenous insulin suppression test are mainly used for scientific purposes. In clinical practice indirect methods are used to assess the relationship between fasting insulin and glucose levels or during the OGTT test. Usually an important symptom suggesting the occurrence of insulin resistance is found in the physical examination of acanthosis nigricans.

The usefulness of mentioned methods to assess insulin sensitivity in children is lower in comparison with results obtained in adults. An important diagnostic problem in the unambiguous assessment of insulin resistance still is the high variability of pulsed insulin secretion - for this reason, it is recommended to evaluate insulinemia several times and use the mean value. Another problem in the pediatric population is the lack of widely recognized standards for different populations/breeds. In European countries, including Poland, type 2 diabetes is still relatively rare, although an increase in the incidence is also observed. The clearly noticeable increase in the number of children with abnormal results of the OGTT test in insulin secretion is an increasingly alarming problem.

The mechanisms leading to complete B cell dysfunction in the field of glycemic control and the full development of type 2 diabetes are complicated, usually this process takes a long time. This creates a real chance to stop the glycemic control disorder at the stage of obesity with insulin resistance or the prediabetes period. Currently, studies are being carried out on the possibility of reversing these disorders, and metformin has been used for this purpose for years. But there still is an important issue: the necessity of introducing constant changes regarding the way of eating and lifestyle. 


\section{Zaburzenia lipidowe $w$ otyłości dziecięcej i wczesne ryzyko miażdżycy - współpraca na linii lekarz - dietetyk}

\section{Lipid profile disturbances in obese children and the risk for the early atherosclerosis development - cooperation between physician - dietician}

Paweł Matusik

Katedra i Klinika Pediatrii i Endokrynologii Dziecięcej, Śląski Uniwersytet Medyczny w Katowicach

Zaburzenia w zakresie profilu lipidowego należą do najczęstszych powikłań metabolicznych towarzyszących otyłości wieku rozwojowego. Ponadto należy pamiętać o fakcie, że zmiany miażdżycowe rozwijają się już w okresie rozwojowym i intensywność tego procesu będzie bezpośrednio przekładać się na wczesne ryzyko powikłań sercowo-naczyniowych w tej grupie chorych. W związku z tym tematem wykładu będzie podsumowanie i krytyczna ocena dostępnych danych na temat występowania poszczególnych zaburzeń profilu lipidowego i związku z wczesnym ryzykiem miażdżycy u otyłych dzieci. Omówione zostaną także aspekty praktycznego postępowania z dzieckiem otyłym ze współistniejącymi zaburzeniami profilu lipidowego i rola, jaką pełnią w procesie leczenia poszczególni członkowie zespołu terapeutycznego, ze szczególnym omówieniem współpracy na linii lekarz - dietetyk. Ponadto zostaną przestawione zasady ewentualnego zastosowania leków hipolipemizujących w tej grupie pacjentów.

Lipid profile disturbances are among the most common metabolic complications associated with obesity in developmental age. In addition, it should be remembered that atherosclerotic plaques develop already during the developmental period and the intensity of this process will directly translate into the early risk of cardiovascular events in this group of patients. Therefore, the subject of the lecture will be a summary and critical evaluation of available data on the occurrence of disturbances of the lipid profile and relationship with the early risk of atherosclerosis with obese children. The aspects of practical treatment of an obese child with co-existing lipid profile disorders and the role of therapeutic team members in the treatment process will also be discussed, that a special discussion on cooperation between a physician and a dietician. In addition, the principles of the possible use of hypolipemic drugs in this group of patients will be presented.

\section{SESJA IV: Psychopatologia}

w otyłości wieku rozwojowego Patronat: Sekcja Psychologii Zdrowia Polskiego Towarzystwa Psychologicznego

\section{Otyłość dziecięca i jej psychologiczne konsekwencje}

Anna Brytek-Matera

Uniwersytet SWPS, Wydział Zamiejscowy w Katowicach

Otyłość uznana została przez Światową Organizację Zdrowia za chorobę cywilizacyjną, gdyż stanowi zagrożenie zdrowia publicznego na świecie. Dane dotyczące otyłości dziecięcej są bardzo niepokojące. Blisko co piąte europejskie i co ósme polskie dziecko ma nieprawidłową masę ciała (Zgliczyński, 2015). Przypuszcza się, że jeśli obecne tendencje się utrzymają, około 70 milionów dzieci będzie miało nadwagę lub otyłość (do 2025 r.), a nadmierna masa ciała stanie się wiodącym problemem zdrowotnym (Ng i wsp., 2014).

Nadmierna masa ciała poza trwałymi negatywnymi konsekwencjami zdrowotnymi wpływa na funkcjonowanie psychiczne młodych ludzi. Otyłość u dzieci jest związana z istotnymi chorobami wspólistniejącymi, a jej wpływ na zdrowie oraz funkcjonowanie psychiczne odgrywa również istotną rolę w dorosłym życiu (McEachan i wsp., 2016). Stygmatyzowanie, negatywne stereotypy, wiktymizacja czy marginalizacja młodych ludzi z otyłością może mieć poważne konsekwencje zarówno dla zdrowia fizycznego, jak i emocjonalnego.

Liczne wyniki badań pokazują, że na styl życia dziecka oraz jego nawyki żywieniowe wpływają głównie rodzice. Ponieważ rezultaty badań dowodzą, że rodzice nie potrafią prawidłowo odżywiać swoich dzieci (Weker i wsp., 2017), niezwykle ważne jest kształtowanie umiejętności rodzicielskich w zakresie promowania zdrowych zachowań i nawyków żywieniowych w kluczowym okresie rozwoju dziecka, jakim jest dzieciństwo. Działania interwencyjne, poza podnoszeniem wiedzy $\mathrm{z}$ zakresu zdrowego odżywiania się oraz znaczenia aktywności fizycznej dla ogólnego funkcjonowania dziecka, powinny obejmować także wsparcie psychologiczne dla dzieci i ich rodzin oraz zalecenia dotyczące zmiany stylu życia, tak aby zapobiec otyłości w życiu dorosłym.

$\mathrm{Z}$ uwagi na fakt, że otyłość jest czynnikiem ryzyka wielu zaburzeń medycznych, problemów psychospołecznych oraz nadmiernej śmiertelności konieczne jest opracowanie skutecznych (szeroko dostępnych i wdrażanych) metod leczenia.

Nie ulega wątpliwości, że powstrzymanie pandemii otyłości wśród dzieci i młodzieży powinno stać się zada- 
niem priorytetowym $\mathrm{w}$ ogólnoświatowej polityce zdrowotnej.

\section{Geneza zachowań żywieniowych przez pryzmat systemowego modelu funkcjonowania rodziny}

\section{The genesis of nutritional behaviour in the prism of the systemic model of the family functioning}

Agnieszka Pasztak-Opitka , Agnieszka Zachurzok²

IInstytut Psychologii, Wydział Pedagogiki i Psychologii, Uniwersytet Śląski w Katowicach

${ }^{2}$ Klinika Pediatrii i Endokrynologii Dziecięcej, Wydział Lekarski, Śląski Uniwersytet Medyczny w Katowicach

Wstęp: Nadwaga i otyłość stanowią istotny problem zdrowotny współczesnych dzieci. Zaprezentowano model systemowych uwarunkowań zachowań żywieniowych $\mathrm{w}$ rodzinach dzieci $\mathrm{z}$ otyłością, u podłoża którego leżą trzy bazowe koncepcje teoretyczne: Mandala Zdrowia Hancocka i Perkins, Model Kołowy Olsona oraz koncepcja stylów wychowania Baumrind.

Materiał i metody: Prezentowany model opiera się na 4 hipotezach: 1) ocena systemu rodzinnego oraz style wychowawcze prezentowane przez rodziców kształtują zachowania żywieniowe w rodzinie; 2) istotne znaczenie w kwestii kształtowania i zmiany zachowań żywieniowych odgrywa otyłość członków rodziny oraz percepcja otyłości dziecka; 3) zachowania żywieniowe dziecka regulowane są przez czynniki wewnętrzne (tj. cechy temperamentalne) oraz zewnętrzne (np. zachowania żywieniowe rodziców i cechy środowiska, w jakim funkcjonuje rodzina); 4) na zachowania żywieniowe istotny wpływ wywiera status socjoekonomiczny rodziny oraz jego konsekwencje.

Wyniki: Dokonano przeglądu badań uzasadniających założenia modelu.

Wnioski: Otyłość częściej pojawia się u rodziców stosujących styl autorytarny, permisywny lub obojętno-odrzucający, a styl demokratyczny okazuje się najbardziej korzystny w jej zapobieganiu i kształtowaniu właściwych nawyków żywieniowych. Umiarkowane poziomy spójności i elastyczności, prawidłowa komunikacja oraz wysoki poziom satysfakcji z życia rodzinnego sprzyjają kształtowaniu właściwych zachowań żywieniowych. Otyłość matki jest silnym predyktorem otyłości dziecka. Otyłość rodzica sprzyja zaniżaniu wagi dziecka i bagatelizowaniu problemu, co utrudnia podejmowanie skutecznej interwencji i zmianę niewłaściwych zachowań żywieniowych w rodzinie. Cechy temperamentalne dziecka sprzyjają kształtowaniu zachowań żywieniowych i mogą wpływać na pojawianie się otyłości w późniejszym wieku. Niewłaściwe zachowania żywieniowe rodziców (rozhamowanie dietetyczne, restrykcje dietetyczne, brak kontroli nad własną dietą) sprzyjają kształtowaniu niewłaściwych zachowań żywieniowych u dzieci. Dodatkowo, kształtowaniu prawidłowych nawyków żywieniowych dziecka sprzyjają: wyższe wykształcenie rodziców, wyższy poziom ich dochodów, struktura rodziny (np. rodzina pełna), większa ilość czasu spędzanego $\mathrm{z}$ rodzicami, zdrowy styl życia rodziców (właściwa dieta i podejmowana aktywność fizyczna).

Introduction: Overweight and obesity are essential health problems of today's children. The aim is to propose a model of systemic determinants of eating behaviour, inspired by three basic theoretical concepts: the Mandala of Health by Hancock and Perkins, the Circumplex Model by Olson and the concept of the parenting styles by Baumrind.

Material and methods: The presented model is based on 4 hypotheses: 1 . Assessment of the family system and parenting styles presented by parents shape eating behaviour in the family. 2. Obesity of family members and perception of the child's obesity play an important role in shaping and changing eating behaviour. 3 . The child's eating behaviour are regulated by internal factors (i.e. temperamental traits) and external (e.g. parental eating behaviour and environmental characteristics in which the family functions). 4. Eating behaviour is affected by the socioeconomic status of the family and its consequences.

Results: The research justifying the assumptions of the model was reviewed.

Conclusions: Obesity appears more often in children of parents applying the authoritative, permissive or rejecting-uninvolved style, while the democratic style proves to be the most favourable for its prevention and for developing proper eating habits. Moderate levels of cohesion and flexibility, correct communication and a high level of satisfaction with the family life are conducive to shaping proper eating behaviour. Maternal obesity is a strong predictor of childhood obesity. Parental obesity favours underestimation of the child's weight and downplaying the problem, which makes it difficult to undertake effective intervention and change inappropriate eating behaviour in the family. The children's temperamental traits foster the development of incorrect eating behaviour and obesity at a later age. Parents' improper eating behaviour (dietary disinhibition, diet restrictions, lack of dietary self-control) favour the development of improper eating behaviour in children. The development of children's correct eating habits is fostered by: higher education of parents, higher income level, family structure (e.g. full family), more time devoted by parents to their children, parents' healthy lifestyle (proper diet and physical activity). 


\section{Spójność jako cecha systemu w rodzinach dzieci z otyłością prostą}

\section{Cohesion as attribute of family system in the families with obese child}

Agnieszka Zachurzok

Katedra i Klinika Pediatrii i Endokrynologii Dziecięcej, Śląski Uniwersytet Medyczny w Katowicach

Wstęp: Otyłość u dzieci i młodzieży traktowana jest jako jeden z poważniejszych problemów zdrowotnych we współczesnym świecie. Celem badania była ocena funkcjonowania systemów rodzinnych dzieci z otyłością prostą z perspektywy dziecka i jego rodzica. Dodatkowo badano opinie rodziców na temat przyczyn dziecięcej otyłości, jej konsekwencji oraz sposobów leczenia.

Material i metody: Badaniami objęto 62 diady rodzic-dziecko. Badano dzieci w wieku 11-18 lat, leczone w Poradni Chorób Metabolicznych GCZD w Katowicach. Ostatecznej analizie poddano 46 zestawów kwestionariuszy. Grupy dziewcząt i chłopców były niemal równoliczne. W badaniu uczestniczyło $87 \%$ matek oraz 13\% ojców. Wykorzystano ankietę stworzoną na potrzeby badania, pozwalającą ocenić poglądy rodziców na temat otyłości oraz Family Adaptability and Cohesion Evaluation Scales (FACES IV) Olsona, w polskiej adaptacji Margasińskiego. Od strony medycznej oceniano BMI dziecka i rodzica.

Wyniki: Tylko 2 (7\%) dzieci miało szczupłych rodziców. Jednocześnie paradoksalnie mniej niż połowa (48\%) rodziców deklarowała problemy $\mathrm{z}$ odżywianiem $\mathrm{w}$ rodzinie, nie łącząc $\mathrm{z}$ nimi własnej otyłości. Za najważniejszą przyczynę otyłości dziecka rodzice uznali słabą aktywność fizyczną (87\%) oraz błędy dietetyczne (87\%). Do najważniejszych konsekwencji otyłości zaliczyli problemy psychologiczne (65\%) i słabą kondycję fizyczną (65\%). Rodzice dziewcząt dodatkowo akcentowali problemy społeczne oraz choroby somatyczne, a rodzice chłopców - nieatrakcyjny wygląd i ryzyko przedwczesnej śmierci. Za najważniejsze w terapii uznali zmiany w diecie (87\%) i aktywności fizycznej (72\%), jednak ponad połowa (65\%) podkreśliła konieczność zmiany stylu życia samego dziecka, ale nie całej rodziny. Spośród dzieci $57 \%$ i jedynie $30 \%$ rodziców uznało system rodzinny za zrównoważony $(p=0,01)$. Również wskaźnik spójności i wskaźnik ogólny funkcjonowania rodziny zostały wyżej ocenione przez dzieci aniżeli rodziców $(1,0 \pm 0,4$ vs 0,7 $\pm 0,3, p=0,02 ; 1,0 \pm 0,4 v s 0,8 \pm 0,3, p=0,004)$. Obserwowano dość wysokie oceny komunikacji i zadowolenia z funkcjonowania rodziny w grupach dzieci i rodziców.

Wnioski: Jak pokazują liczne badania, koniecznym warunkiem skutecznej interwencji w leczeniu otyłości u dziecka jest wprowadzenie zmian stylu życia całej rodziny. Tymczasem większość rodziców podkreśliła konieczność zmiany funkcjonowania samego dziecka, mimo, że byli to rodzice $\mathrm{z}$ nadmierną masą ciała. Rodzice posiadali właściwą wiedzę na temat otyłości, nie widzieli jednak potrzeby zmiany własnych nawyków oraz zaprzeczali zaburzeniom odżywiania w rodzinie. Leczeniu otyłości sprzyja optymalny poziom spójności, tymczasem rodzice gorzej oceniali spójność niż dzieci. Wszystkie te aspekty potwierdzają tezę, że funkcjonowanie w środowisku otyłościogennym stanowi czynnik utrudniający terapię otyłości.

Introduction: Childhood obesity has become serious public health problem in today's word. The cause of excessive body weight is usually seen in caloric reach diet and poor physical activity. However its background is much more complicated, involving genetic and epigenetic factors, but also social and family habits as well personal temperamental features and psychological problems.

Objective: The aim of the study was to assess the family system functioning in obese children from the perspective of obese child and parent and to compare these perceptions.

Material and methods: Forty six pairs were included into the study. Children group comprises 22 (48\%) boys and $24(52 \%)$ girls in the age 11-18 years (13.0 \pm 1.9 years) with simple obesity, with BMI $>97$ percentile (BMI $z$-score $2.1 \pm 0.3$, range 1.5-2.9). In the parent group $87 \%$ mothers and $13 \%$ fathers were examined. In children weight and height were measured, BMI and BMI $z$-score were calculated. Polish version of Family Adaptability and Cohesion Evaluation Scales (FACES IV) by D. Olson was performed in dyads. In parents the questionnaire formulated for our research was carried out.

Results: Only parents of 2 (7\%) children had BMI within the normal range. According to the information given in the questionnaire problems with weight in the family were declared by significantly less parents -22 (48\%). The low physical activity (87\%) and inappropriate diet $(87 \%)$ were given as the most common reason of child's obesity. Psychological problems (65\%) and poor physical fitness $(65 \%)$ were the most common consequences of childhood obesity according to parents. Parents of girls emphasized additionally social problems and somatic disorders, whereas boys' parents - unattractive look and premature death. The most effective therapeutic factors were to comply with diet (87\%), increase physical activity $(72 \%)$ and change of lifestyle of the child (65\%). The families were assessed as balanced according to $57 \%$ of children and $30 \%$ of parents $(p=0.01)$. Also cohesion index and main index were significantly higher in children's perception then parents' $(1.0 \pm 0.4$ vs. $0.7 \pm 0.3, p=$ $0.02 ; 1.0 \pm 0.4$ vs. $0.8 \pm 0.3, p=0.004$, respectively).

Conclusions: As many researches show the condition essential to effective therapy of childhood obesity is the 
lifestyle change of the whole family. While most of parents, in majority also obese, underline the need of change only in child's functioning. Parents had the knowledge about cause and consequences of obesity, but they did not see the need of change of their own habits and denied the presence of excessive body weight in the family. Optimal cohesion level is essential for effective treatment, while parents perceived cohesion in their families lower than children. Our observation confirm that obesogenic family with some aberration in functioning could lead to many difficulties in obesity therapy.

\section{SESJA V: Otyłość jako powikłanie i przyczyna zaburzeń \\ Patronat: Polskie Towarzystwo Badań nad Otyłościa (PTBO)}

\section{Otyłość jako problem po leczeniu choroby nowotworowej w dzieciństwie}

\section{Obesity in childhood cancer survivors}

Jerzy Konstantynowicz, Paweł Abramowicz, Katarzyna Filipczuk

Klinika Pediatrii, Reumatologii, Immunologii i Chorób Metabolicznych Kości, Uniwersytet Medyczny w Białymstoku

Otyłość ma związek $\mathrm{z}$ nowotworami w wieku dorosłym, stanowiąc zarówno udokumentowany czynnik ryzyka licznych nowotworów (np. rak jelita grubego, nowotwór piersi u kobiet po menopauzie, trzonu macicy, gruczolakorak przełyku, wpustu żołądka, trzustki, wątroby, nerki), jak i powikłanie nowotworów i leczenia onkologicznego. Dane na temat powiązań nowotworów $\mathrm{z}$ otyłością $\mathrm{w}$ wieku rozwojowym są niejednoznaczne. W ostatnich dekadach, za sprawą postępu w terapii, znacznie wzrosła populacja ozdrowieńców po wyleczeniu choroby nowotworowej w dzieciństwie (childhood cancer survivors - CCS), prowadząc jednocześnie do narastania wtórnych problemów zdrowotnych i późnych powikłań, m.in. nowotworów wtórnych, chorób sercowo-naczyniowych (CVD) z kardiomiopatią, zaburzeń endokrynnych i metabolicznych (zaburzenia wydzielania $\mathrm{GH}$, niedobór wzrostu, niedoczynność tarczycy, hipogonadyzm), a także nadwagi i otyłości. Niedawne badania wykazały również przyspieszony rozwój chorób serca, zagrożenia udarem i cukrzycą typu 2 u ozdrowieńców. Skala zjawiska jest zróżnicowana, ale nadmierna masa ciała dotyczy nawet $50 \%$ populacji osób leczonych $\mathrm{w}$ dzieciństwie $\mathrm{z}$ powodu nowotworów. Do dysfunkcji metabolicznych i otyłości prowadzą w szczególności choroby rozrostowe krwi, takie jak ostra białaczka limfoblastyczna (acute lymphoblastic leukemia - ALL) i chłoniaki oraz guzy mózgu. Mimo prawidłowej masy ciała wyrażonej wskaźnikiem BMI, dzieci leczone onkologicznie oraz CCS mają zazwyczaj nadmierną zawartość całkowitej tkanki tłuszczowej, z przeważającą otyłością brzuszną i otłuszczeniem wisceralnym. Do najważniejszych czynników ryzyka otyłości w pediatrycznych schorzeniach nowotworowych zalicza się otyłość przedchorobową (w momencie diagnozy), rodzaj stosowanej chemioterapii (w tym redystrybucję tłuszczu ustrojowego wskutek glikokortykoterapii) i radioterapię w wysokich dawkach. Naświetlanie ośrodkowego układu nerwowego w dawce $\geq 20$ Gy - zwłaszcza 
w ALL - stanowi niezależny czynnik ryzyka otyłości, poprzez negatywne oddziaływanie na funkcje podwzgórza i zaburzenie osi podwzgórzowo-przysadkowej. Inne patomechanizmy prowadzące do otyłości u CCS obejmują czynniki demograficzne (płeć), statyczny tryb życia, częste hospitalizacje, nieadekwatny bilans energetyczny. Oprócz zwiększonego ryzyka CVD i cukrzycy, stwierdzanego w otyłości prostej, otyłość indukowana nowotworami w dzieciństwie może powodować kumulację niekorzystnych czynników ryzyka, szczególnie u ozdrowieńców z ALL. Dlatego otyli pacjenci z ALL wymagają wnikliwego oszacowania ryzyka sumarycznego, monitorowania chorób współistniejących, wczesnych działań profilaktycznych i wczesnej celowanej interwencji. Postępowanie indywidualne (spersonalizowane) w otyłości związanej z leczeniem onkologicznym w dzieciństwie jest kluczowe dla czasu przeżycia, zmniejszenia późniejszych powikłań metabolicznych oraz poprawy/optymalizacji jakości życia.

The link between obesity and cancers in adults has been demonstrated in many observational and prospective studies. Excessive body fat confers the risk of some cancers (e.g., pancreatic, colorectal, hepatic, kidney, esophageal adenocarcinoma, postmenopausal breast cancer) and, on the other hand, may be a long-term complication of anti-cancer therapy itself. Over the past decades, the number of childhood cancer survivors has increased significantly due to advances in diagnostic and treatment methods. In childhood population, the associations between cancer and obesity are not yet thoroughly investigated whereas the data are inconsistent. Long-term prospective studies have shown that the large proportion of pediatric cancer survivors is affected by late-onset health problems and poor outcomes, including secondary malignancies, cardiovascular conditions (e.g., cardiomyopathy), metabolic and endocrine abnormalities (hypothyroidism, hypogonadism, impairment of growth-hormone secretion, short stature), as well as overweight and obesity. Recently, evidence has been also reported on developing heart disease, stroke, and type 2 diabetes relatively early in life among these survivors. Cancer-associated obesity may be related to a higher risk of relapse, especially in acute lymphoblastic leukemia (ALL) survivors. It is reported that excessive weight gain affects even up to $50 \%$ of cancer survivors, in particular following treatment of lymphomas, ALL and brain tumors. Although survivors of childhood brain tumors have a similar body mass index (BMI) to healthy non-cancer controls, they have excessive total fat tissue content with a significantly increased central (abdominal) adiposity. The prevalence of this complication depends on the pre-morbid weight at diagnosis (via the mechanism of early adiposity rebound), sex, type of the therapy used (higher adiposity in ALL treated with high doses of irradiation, glucocorticoid-induced persistent fat redistribution). The cranial irradiation $\geq 20 \mathrm{~Gy}$ is regarded as an independent obesogenic factor due to its negative influence on CNS, and the deleterious effect on hypothalamus and hypothalamic-pituitary axis. The potential etiology of excess weight gain in survivors also includes sedentary lifestyle, long-lasting hospitalizations and deteriorated energy expenditure, and inadequate dietary intakes. Aside from an increased cardiovascular disease (CVD) risk, similar to that found in general population, this specific cancer-associated obesity may lead to a higher additional cumulative risk of such events, in particular among ALL survivors. The patients need, therefore, further careful investigations for factors escalating their risk of CVD and type 2 diabetes. Thus, the long-term monitoring, new prevention strategies and comprehensive targeted treatment of obesity in childhood cancer survivors with obesity are essential to avoid or minimize severe metabolic consequences of excess body weight, to improve survival, and optimize the quality of life.

\section{Czy nadmiar masy ciała u dzieci sprzyja niedoborowi witaminy $\mathrm{D}$ ?}

\section{If excess body weight foster vitamin $D$ deficiency in children?}

\section{Elżbieta Jakubowska-Pietkiewicz}

Klinika Propedeutyki Pediatrii i Chorób Metabolicznych Kości, Uniwersytet Medyczny w Łodzi

Otyłość i niedobór witaminy D stanowią obecnie narastający problem zdrowia publicznego, szczególnie istotny w populacji wieku rozwojowego, ze względu na skutki zdrowotne, zasięg oraz szybko narastającą częstość występowania. Otyłe dzieci i młodzież predysponowani są do ogólnoustrojowych niedoborów witaminy D (stężenie kalcyfediolu, 25-hydroksywitaminy $\mathrm{D}<30 \mathrm{ng} / \mathrm{ml}$ ), a problem ten pojawia się w okresie przedszkolnym i osiąga swój szczyt w wieku 14-18 lat.

Witamina D poprzez swoje działanie receptorowe i pozareceptorowe reguluje w organizmie funkcje licznych genów, które działają klasycznie oraz plejotropowo m.in. w tkance tłuszczowej. Tkanka tłuszczowa, jako układ endokrynny, z jednej strony uczestniczy w regulacji metabolizmu witaminy D przy udziale leptyny i adiponektyny, z drugiej zaś sama podlega procesom metabolicznym zależnym od tejże witaminy. Prawidłowy poziom witaminy D łączy się z wyższymi stężeniami leptyny, co zapobiega otyłości, obniżony prowadzi natomiast do wzrostu stężenia parathormonu i kalcytriolu i w konsekwencji do odkładania się tłuszczu. Wśród głównych przyczyn niedo- 
boru witaminy $\mathrm{D}$ w organizmie osób otyłych wymienia się niedostateczną syntezę skórną, która może wynikać $\mathrm{z}$ unikania ekspozycji na promieniowanie słoneczne, oraz zmniejszenie jej biodostępności na skutek sekwestracji w tkance tłuszczowej. Zwiększona ilość podskórnej tkanki tłuszczowej u dzieci i młodzieży z otyłością zatrzymuje witaminę D i utrudnia tym samym jej transport i dalsze wykorzystanie w procesach metabolicznych. Prowadzi także do zwiększenia stężenia leptyny, która działając endokrynnie, wpływa na syntezę aktywnego metabolitu witaminy D w nerce, a poprzez swoje działanie miejscowe $\mathrm{w}$ adipocytach przerywa cykl akumulacji tłuszczu.

U otyłych dzieci i młodzieży obserwowane jest zatem zwiększone zapotrzebowanie na witaminę $\mathrm{D}$, wynikające ze złożonych procesów endokrynologicznych i metabolicznych, które podlegają wzajemnej regulacji.

Obesity and vitamin D deficiency are increasingly becoming a significant public health problem, particularly critical in adolescence-age population due to their health effects, extent and rapidly growing prevalence. Obese children and youth are predisposed to systemic vitamin $\mathrm{D}$ deficiencies (calcifediol concentration $<30 \mathrm{ng} / \mathrm{ml}$ ), as this problem emerges in preschool age and peaks between the ages of 14 and 18.

Through its receptive and extra-receptive activity, vitamin D regulates functions of several genes, which act classically and pleiotropically in adipose tissue inter alia. As an endocrine system, fat participates in regulating vit. $\mathrm{D}$ metabolism with leptin and adiponectin on one hand. On the other, it itself is directly affected by metabolic processes depending on vitamin D. Correct level of vitamin D relates to higher leptin concentration, which prevents obesity, however lower levels lead to an increased concentration of parathormone and calcitriol, and in consequence - to fat depositing. Among the main reasons behind vitamin $\mathrm{D}$ deficiencies in obese people insufficient epidermal synthesis is being mentioned. It may be caused by avoiding sunray exposure and limiting its bioavailability due to sequestration in body fat. The increased amount of subcutaneous adipose tissue in obese children and youth halts vitamin D and hinders it from being transported and further use in metabolic processes. It also leads to an increased concentration of leptin, which in turn endocranially affects active vitamin D metabolite synthesis in the kidney, and by its site effects in adipocytes breaks the fat accumulation cycle.

An increased demand for vitamin D is therefore observed in obese children and youth, as an effect of complex endocrine and metabolic processes influencing one another.

\section{Otyłość wieku rozwojowego a gęstość mineralna kości i ryzyko złamań}

\author{
Bone mineral density and fractures risk in the obese \\ children
}

Paweł Matusik

Katedra i Klinika Pediatrii i Endokrynologii Dziecięcej, Śląski Uniwersytet Medyczny w Katowicach

Wpływ nadmiaru tłuszczowej masy ciała na układ kostny jest tematem wielu badań $\mathrm{i}$ analiz, których wyniki są często sprzeczne. W związku z tym tematem wykładu będzie próba odpowiedzi na pytanie, w jaki sposób - pozytywny czy negatywny - otyłość dziecięca wpływa na jakość tkanki kostnej, ocenianą poprzez badania obrazowe i markery kostne. Omówione zostaną także aspekty związane $\mathrm{z}$ właściwą interpretacją badań DXA w tej grupie pacjentów. Zostaną również przedstawione informacje związane ze zmianami w zakresie metabolizmu kostnego i ryzyka złamań u pacjentów poddanych efektywnemu leczeniu odchudzającemu, ze szczególnym określeniem ewentualnego negatywnego wpływu operacji bariatrycznych wykonywanych w okresie rozwojowym.

The influence of excess body fat on the skeletal system is the subject of many studies and analyzes, the results of which are often contradictory. Therefore, the subject of the lecture will be an attempt to answer the question of how positive or negative childhood obesity affects the quality of bone tissue, assessed by imaging methods and bone markers. The aspects related to the correct interpretation of DXA in this group of patients will also be discussed. Information related to changes in bone metabolism and fracture risk in patients undergoing effective weight loss treatment will also be presented, with particular reference to the possible negative impact of bariatric operations performed during the developmental period. 
SESJA VI: Funkcjonalność przewodu pokarmowego jako kluczowy element profilaktyki i terapii Patronat: Oddział Śląski Polskiego Towarzystwa Pediatrycznego (PTP)

\section{Kształtowanie zwyczajów żywieniowych w profilaktyce otyłości}

Piotr Socha

Oddział Gastroenterologii, Hepatologii i Zaburzeń Odżywiania, Instytut „Pomnik - Centrum Zdrowia Dziecka” w Warszawie

\section{Modyfikacja flory jelitowej - płonne nadzieje czy możliwość realnych korzyści}

Modification of the intestinal flora - futile hopes or
possible real benefits

Urszula Grzybowska-Chlebowczyk

Klinika Pediatrii, Katedra Pediatrii, Śląski Uniwersytet Medyczny w Katowicach

Prawidłowa mikrobiota jelitowa jest ważnym czynnikiem warunkującym właściwe funkcjonowanie całego organizmu - wpływa na metabolizm, produkcję witamin, trawienie i wchłanianie składników odżywczych, rozwój narządów, utrzymuje integralność bariery śluzówkowej i tkanki limfoidalnej oraz rozwój i funkcję układu immunologicznego, neurogennego i osi jelita-mózg. Jest niezbędna do prawidłowego funkcjonowania organizmu i odgrywa bardzo ważną rolę w patogenie zaburzeń metabolicznych.

Dieta wysokoenergetyczna wpływa na skład mikrobioty jelitowej - rozwija się tzw. mikrobiota sprzyjająca otyłości (obesogenic microbiota). W otyłości obserwuje się odmienny skład mikrobioty - mniejszą ilość Bacteroides i zwiększoną Firmicutes. Zaburzenie składu mikrobioty jelitowej powoduje zwiększenie pozyskiwania energii z pożywienia i zmniejszenie jej zużycia. Oddziaływanie mikrobioty jelitowej na homeostazę energetyczną organizmu może zachodzić na wielu płaszczyznach i nazywane jest hipotezą magazynowania - the storage hipotesis.

Zmiana diety oraz stosowanie pre- i probiotyków prowadzi do korzystnej modyfikacji mikrobioty jelitowej. Ostatnio prowadzone są badania nad skutecznością transplantacji mikrobioty jelitowej w leczeniu otyłości. Mikroorganizmy w różny sposób wpływają na syntezę poszczególnych KKT, co również może być wykorzystane w terapii zaburzeń metabolicznych.
Correct intestinal microbiota is an important factor conditioning the proper functioning of the whole organism - affects metabolism, vitamin production, digestion and absorption of nutrients, organ development, maintains the integrity of the mucosal barrier and lymphoid tissue and the development and function of the immune and neurogenic systems and brain bowel axis. Intestinal microbiota is essential for the proper functioning of the body and plays a very important role in the pathogen of metabolic disorders.

High-energy diet affects the composition of intestinal microbiota - so-called obesogenic microbiota develops. In obesity, a different composition of microbiota is observed - a smaller amount of Bacteroides and increased Firmicutes. Disturbing the composition of intestinal microbiota increases the energy gain from food and reduces its consumption. The effect of intestinal microbiota on the body's energy homeostasis can occur on many levels and it is called "the storage" hypothesis.

Changing the diet and the use of pre and probiotics leads to a beneficial modification of the intestinal microbiota. Recently, research has been conducted on the efficacy of intestinal microbiota transplantation in the treatment of obesity. Microorganisms in various ways affect the synthesis of individual SCFAs, which can also be used in the therapy of metabolic disorders.

\section{Noworodek matki otyłej}

Maria Katarzyna Borszewska-Kornacka

Klinika Neonatologii i Intensywnej Terapii Noworodka, Warszawski Uniwersytet Medyczny

\section{Problemy dziecka otyłego w praktyce gastroenterologicznej}

\section{Problems of obese children in gastroenterological practice}

\section{Sabina Więcek}

Klinika Pediatrii, Śląski Uniwersytet Medyczny w Katowicach Górnośląskie Centrum Zdrowia Dziecka w Katowicach

Otyłość oraz jej związek przyczynowo-skutkowy z wieloma chorobami ze względu na skalę i powszechność są bardzo istotnym problemem zdrowotnym XXI w. Problem otyłości i nadwagi dotyczy $10 \%$ dzieci i młodzieży na świecie. Szacuje się, że do 2025 r. będzie 177 milionów 5-17-latków z nadwagą oraz 91 milionów z otyłością. Udowodniono wpływ otyłości na występowanie wielu schorzeń przewodu pokarmowego. U 70-90\% pacjentów otyłych obserwuje się zaburzenia czynnościowe przewo- 
du pokarmowego, najczęściej w postaci refluksu żołądkowo-przełykowego i/lub zespołu jelita drażliwego. Jednym z częstszych problemów jest również kamica pęcherzyka żółciowego i jej następstwa (zapalenie pęcherzyka żółciowego, kamica przewodowa i/lub ostre żółciopochodne zapalenie trzustki), niealkoholowe stłuszczeniowe zapalenie wątroby mogące prowadzić do marskości wątroby i niewydolności tego narządu. Coraz większym problemem wydaje się zwiększone zachorowanie na choroby nowotworowe przewodu pokarmowego (przełyku, jelita grubego, wątroby i trzustki), w następstwie otyłości również w populacji ludzi młodych. Udowodniono, że zaburzenia immunologiczne towarzyszące otyłości odgrywają ponadto rolę $\mathrm{w}$ patogenezie chorób autoimmunizacyjnych przewodu pokarmowego (PBC, PSC, AIH).

$\mathrm{W}$ prezentacji przedstawiono najczęstsze problemy gastrologiczne w populacji dzieci otyłych, uwzględniając epidemiologię, objawy kliniczne, diagnostykę oraz leczenie.

Obesity, due to its prevalence and its causal relationship with many diseases, poses an important health problem of the $21^{\text {st }}$ century. The problem of obesity and overweight concerns $10 \%$ of children and adolescents worldwide. It is estimated that by 2025 , there will be 177 million of 5-17-year olds with overweight and 91 million with obesity. The influence of obesity on the occurrence of many diseases of the gastrointestinal tract has been proven. Functional disorders of the gastrointestinal tract, usually in the form of gastro-oesophageal reflux and/or irritable bowel syndrome, are observed in 70-90\% of obese patients. One of the most common problems is also cholelithiasis and its consequences (cholecystitis, choledocholithiasis and/or acute biliary pancreatitis) as well as non-alcoholic steatohepatitis that may lead to liver cirrhosis and failure. Increasing incidence of neoplastic diseases of the gastrointestinal tract (i.e. oesophagus, colon, liver and pancreas) as a result of obesity, also in the population of young people, seems to be a growing problem. It has been proven that immune disorders accompanying obesity also play a role in the pathogenesis of autoimmune diseases of the gastrointestinal tract (PBC, PSC, AIH).

The presentation shows the most common gastrointestinal problems in the population of obese children, including epidemiology, clinical symptoms, diagnostics and treatment.

\section{Czynniki ryzyka niealkoholowej stłuszczeniowej choroby wątroby (NAFLD) u otyłych dzieci}

\author{
Risk factors for nonalcoholic fatty liver disease \\ (NAFLD) in obese children
}

Zofia Prokopowicz, Ewa Małecka-Tendera, Paweł Matusik

Katedra i Klinika Pediatrii i Endokrynologii Dziecięcej, Śląski Uniwersytet Medyczny w Katowicach

Wstęp: Niealkoholowa stłuszczeniowa choroba wątroby (nonalcoholic fatty liver disease - NAFLD) jest najczęstszą przyczyną przewlekłej choroby wątroby u dzieci. Rokowanie zależy w głównej mierze od szybkiego jej rozpoznania w okresie bezobjawowym i wdrożenia skutecznej terapii, która daje szanse na wyleczenie lub przynajmniej spowolnienie progresji choroby.

Cel pracy: Celem pracy była ocena częstości występowania NAFLD w badanej populacji, a także identyfikacja antropometrycznych i metabolicznych czynników ryzyka wystąpienia NAFLD u otyłych dzieci.

Materiał i metody: Badaniem objęto 108 otyłych dzieci. U wszystkich pacjentów wykonano pomiary antropometryczne i badania biochemiczne. Niealkoholową stłuszczeniową chorobę wątroby rozpoznawano na podstawie hiperechogenicznej wątroby w badaniu ultrasonograficznym i/lub podwyższonego stężenia aminotransferazy alaninowej (ALT). Pacjentów podzielono na 2 grupy: z NAFLD i bez NAFLD, które porównano pod względem cech antropometrycznych, parametrów biochemicznych oraz składowych zespołu metabolicznego.

Wyniki: Niealkoholową stłuszczeniową chorobę wątroby stwierdzono u 49 (45\%) pacjentów, z podobną częstością u obu płci [ 27 chłopców $(55,1 \%)$ vs 22 dziewczynki $(44,9 \%), p=0,089]$. Pacjenci z NAFLD mieli istotnie większy obwód talii, wskaźniki WHR i WHtR, istotnie wyższe stężenia cholesterolu całkowitego, trójglicerydów, glukozy $\mathrm{i}$ insuliny w 120. minucie OGTT oraz insuliny na czczo i wyższe wartości wskaźnika insulinooporności HOMA-IR w porównaniu z grupą pacjentów bez stłuszczenia. W grupie pacjentów z NAFLD zespół metaboliczny rozpoznawano istotnie częściej niż u pacjentów bez stłuszczenia (40,82\% vs 22,81\%, $p=0,04)$. Najlepszym samodzielnym czynnikiem ryzyka dla NAFLD spośród analizowanych parametrów było stężenie insuliny na czczo $(\mathrm{AUC}=0,829$; punkt odcięcia 18,9 uIU/ml).

Wnioski: Niealkoholowa stłuszczeniowa choroba wątroby jest bardzo częstą jednostką chorobową w populacji otyłych dzieci. Czynnikami ryzyka wystąpienia NAFLD są zwiększony obwód talii, podwyższone wskaźniki WHR i WHtR, podwyższone wartości cholesterolu całkowitego, trójglicerydów, insuliny na czczo, glukozy i insuliny w 120. minucie OGTT oraz wskaźnika 
HOMA-IR. Wystąpienie NAFLD zwiększa ryzyko potencjalnych powikłań sercowo-naczyniowych wyrażonych poprzez rozpoznanie zespołu metabolicznego. Najlepszym samodzielnym czynnikiem ryzyka dla rozpoznania NAFLD w populacji otyłych dzieci jest stężenie insuliny na czczo > 18,9 uIU/ml.

Introduction: Nonalcoholic fatty liver disease (NAFLD) is the most common cause of chronic liver disease in obese children. Early diagnosis and treatment are essential for curing or slowing down the disease progression.

Objective: The aim of the study was to assess the prevalence of NAFLD in study population and to identify anthropometrical and metabolic risk factors for NAFLD prediction and its development.

Material and methods: The study included 108 obese children. Anthropometric measurements, NAFLD diagnosis (based on ALT level and/or liver ultrasound), and metabolic syndrome (MS) components were assessed in all patients. Patients were divided into groups with and without NAFLD.

Results: Nonalcoholic fatty liver disease was diagnosed in $49(45 \%)$ patients with similar prevalence in boys (27; 55.10\%) and girls [22 (44.9\%), $p=0.089$ ]. NAFLD patients had significantly greater waist circumference, WHR, and WHtR and significantly higher total cholesterol, triglyceride, and fasting insulin concentrations as well as higher glucose and insulin concentrations in 120 minutes of OGTT and higher HOMA-IR levels compared to group of patients without NAFLD. In NAFLD patients, MS was significantly more likely to be diagnosed than in group with NAFLD ( $40.82 \%$ vs. $22.81 \%, p=0.04)$, Among analysed parameters the best independent risk factor for NAFLD was fasting insulin concentration with the cut-off point $=18.9 \mathrm{uIU} / \mathrm{ml}($ AUC $=0.829)$.

Conclusions: Nonalcoholic fatty liver disease is a very common disease in obese children. NAFLD predictive risk factors include increased waist circumference, elevated WHR and WHtR, and elevated total cholesterol, triglycerides, and fasting insulin as well as elevated glucose and insulin concentration in the OGTT and HOMA-IR index. NAFLD increases the risk of potential cardiovascular complications expressed by diagnosis of metabolic syndrome. The best independent predictive risk factor for diagnosing NAFLD in obese children is fasting insulin $>18.9 \mathrm{uIU} / \mathrm{ml}$.
SESJA VII: Właściwa aktywność fizyczna i sprawność ruchowa - czy to połowa sukcesu leczenia otyłości dziecięcej?

Patronat: Oddziat Śląki Polskiego Towarzystwa Rehabilitacji (PTReh)

\section{Metody oceny i monitorowania aktywności fizycznej u otyłych dzieci i młodzieży}

\section{Methods of assessment and monitoring of physical activity in obese children and adolescents}

Joanna Baran, Artur Mazur

Wydział Medyczny, Uniwersytet Rzeszowski w Rzeszowie

Wstęp: Według najnowszych danych Światowej Organizacji Zdrowia (Health World Organization - WHO) nadwaga i otyłość stanowią największy problem zdrowia publicznego XXI w. Na całym świecie w 2016 r. liczba dzieci $\mathrm{z}$ nadwagą $\mathrm{w}$ wieku poniżej pięciu lat wynosiła $41 \mathrm{mln}$, a ponad $340 \mathrm{mln}$ dzieci w wieku 5-19 lat miało nadwagę lub otyłość. Jako jedną z przyczyn powstawania nadwagi i otyłości podaje się zmniejszoną aktywność fizyczną. WHO rekomenduje spędzanie minimum $60 \mathrm{mi}-$ nut dziennie w aktywności MVPA przez dzieci. Według aktualnych danych $81 \%$ nastolatków w wieku 11-17 lat jest niewystarczająco aktywnych fizycznie.

Materiał i metody: W pracy przedstawiony został przegląd najczęściej stosowanych metod oceny i monitorowania aktywności fizycznej u dzieci i młodzieży z problemem nadwagi i otyłości na podstawie najnowszych wyników badań. Uwzględnione zostały zarówno metody subiektywne (oparte na badaniu z wykorzystaniem kwestionariuszy), jak i obiektywne (oparte na wykorzystaniu m.in. akcelerometrii).

Wyniki: Zaletą kwestionariuszy do oceny aktywności fizycznej jest ich łatwa dostępność oraz mały koszt podejmowanych badań. Wadą natomiast jest to, że jest to ocena subiektywna na podstawie odczuć badanego lub jego rodzica. Niekiedy wyniki mogą być zafałszowane, gdyż badacz nie ma możliwości sprawdzenia rzetelności informacji podanej przez badanego lub rodzica. Akcelerometry natomiast, jako rzetelna, obiektywna metoda oceny aktywności fizycznej, wykorzystywane są w licznych badaniach naukowych. Mogą być stosowane u dzieci, dorosłych, a nawet kobiet w ciąży. Urządzenia te nie emitują żadnego promieniowania, dlatego są bezpieczne dla zdrowia osób badanych. Wykorzystywane są m.in. w badaniach mających na celu walidację skal do oceny aktywności fizycznej w celu sprawdzenia rzetelności wyników. 
Wnioski: Regularna aktywność fizyczna jest jednym z głównych zaleceń mających na celu profilaktykę lub zmniejszenie częstości występowania otyłości u dzieci. Wskazane jest monitorowanie poziomu aktywności fizycznej dzieci z nadwagą i otyłością, zwłaszcza z wykorzystaniem obiektywnych narzędzi pomiarowych.

Introduction: According to the latest the Health World Organization (WHO) data, overweight and obesity are the biggest problem of public health of the $21^{\text {st }}$ century. Worldwide, in 2016 the number of overweight children, under the age of five, was 41 million and over 340 million children aged 5-19 were overweight or obese. One of the causes of overweight and obesity is low level of physical activity. WHO recommends spending at least 60 min per day in MVPA for children. According to current data, $81 \%$ of adolescents aged 11-17 are physically insufficient.

Material and methods: We present an overview of the most commonly used methods of assessment and monitoring of physical activity in children and adolescents with the problem of overweight and obesity based on the latest results. Both subjective methods (based on a questionnaire study) and objective methods (based on the accelerometry) were included.

Results: The advantage of questionnaires to assess physical activity level is their easy availability and low cost of research. The disadvantage is the fact that it is a subjective assessment based on the feelings of the subject or his parent. Sometimes the results may be falsified because the researcher is not able to check the reliability of the information provided by the respondent or parent. Accelerometers, as a reliable, objective method for assessing physical activity, are used in numerous scientific studies. They can be used in children, adults and even pregnant women. These devices do not emit any radiation, therefore they are safe for the health of the subjects. Accelerometers are used, among others in studies aimed at validating scales to assess physical activity in order to check the reliability of results.

Conclusions: Regular physical activity in children is one of the main recommendations aimed at preventing or reducing the incidence of obesity in children. It is advisable to monitor the level of physical activity of children with overweight and obesity, especially with the use of objective measurement tools.

\section{Rola fizjoterapii w leczeniu otyłości wieku rozwojowego}

\author{
The Role of Physiotherapy in Treatment of Obesity \\ in Developmental Age
}

Krzysztof Fabian

Wojewódzki Szpital Rehabilitacyjny dla Dzieci w Jastrzębiu-Zdroju

Występowanie nadmiernej masy ciała ma swoje odbicie w stopniu rozwoju ekonomicznego i cywilizacyjnego społeczeństw. Otyłość jest chorobą przewlekłą prowadzącą do zaburzenia wielu procesów życiowych. Przyczynia się bezpośrednio do uszkodzenia różnych struktur organizmu oraz wpływa na obniżenie jakości życia i jego długości. Jest również czynnikiem predysponującym do powstawania wielu chorób, w tym nadciśnienia tętniczego, cukrzycy typu 2 i przedwczesnego zwyrodnienia narządu ruchu. Nawyki ruchowe dziecka to często odzwierciedlenie aktywności całej rodziny. Szybkie tempo życia, niewłaściwa dieta i zminimalizowanie aktywności ruchowej najmłodszych przekłada się na ich funkcjonowanie w dorosłości. Niezwykle istotna wydaje się szeroko rozumiana edukacja zdrowotna całego społeczeństwa, profilaktyka, a przede wszystkim kompleksowe postępowanie lecznicze oparte na odpowiednio dawkowanej aktywności fizycznej.

The occurrence of excessive body weight is related to the degree of economic and social development of modern societies. Obesity is a chronic disease that leads to malfunction of numerous life processes. Not only does it directly contribute to damage caused to a variety of body structures, but also lowers the quality of life and shortens it. Furthermore, it opens the door to a number of diseases such as hypertension, type II diabetes and premature degeneration of the locomotion organ. Children's physical activity habits most frequently reflect the physical activity scope of their families. Fast paced life, improper diet and minimal physical activity of the youngest impact their functioning in adult life. Thus, broadly understood healthy lifestyle education programmes for the entire society, preventive healthcare and, most significantly, a comprehensive treatment based on adequately prescribed physical exercise seem to be of greatest essence.

\section{Rola treningu marszowego $u$ otyłych dzieci}

The role of walking training in obese children

\author{
Bartosz Wnuk \\ Katedra i Klinika Rehabilitacji, Śląski Uniwersytet Medyczny \\ w Katowicach
}

Aktywność fizyczna jest jednym z podstawowych elementów kompleksowego leczenia otyłości. Systematycz- 
ne uprawianie ćwiczeń fizycznych poprzez zwiększenie wydatku energetycznego sprzyja obniżeniu masy ciała.

Trening marszowy jest najprostszą i najbardziej dostępną formą ćwiczeń aerobowych. Ten rodzaj treningu umożliwia łatwe dawkowanie obciążenia i kontrolę parametrów tętna i ciśnienia krwi w czasie ćwiczeń. Celem pracy jest określenie roli treningu marszowego u otyłych dzieci w kompleksowym leczeniu oraz profilaktyce tego schorzenia. Analiza i interpretacja aktualnej literatury dotyczącej treningu marszowego w otyłości u dzieci jest trudna. Ta forma treningu ma wpływ na wzrost prędkości chodu, zmniejszenie masy ciała, tkanki tłuszczowej oraz obniżenie kosztów energii chodzenia. Trening marszowy w większości przypadków jest stosowany w połączeniu $\mathrm{z}$ innymi formami wysiłku wytrzymałościowego rozszerzonego o ćwiczenia kontroli postawy ciała, rozciągające i wzmacniające mięśnie oraz kształtujące równowagę ciała.

Physical activity is one of the fundamental factors of complex obesity treatment. Regular physical activity results in increased energy consumption, which causes loss of body weight.

Marching training is the simplest and most accessible form of aerobic exercise. This type of training enables easy loading and control of heart rate and blood pressure during exercises. The aim of the study is to determine the role of walking training among obese children in comprehensive treatment and prevention of this disease. The analysis and interpretation of the current literature about marching training in child obesity is difficult. This form of training has impact to grown in walking speed, decreases weight, body fat and reduced energy costs of walking. In most cases, walking training is used in conjunction with other forms of endurance exercise, extended by postural control exercises, stretching and strengthening muscles and shaping the balance of the body.

\section{Analiza wpływu uczestnictwa w programie edukacyjnym „Lekkoatletyka dla każdego" na zachowania żywieniowe i skład ciała młodzieży}

\section{Dominika Głąbska}

Katedra i Zakład Dietetyki, Wydział Nauk o Żywieniu Człowieka i Konsumpcji, SGGW w Warszawie

\section{SESJA VIII: Otyłość olbrzymia}

u nastolatków - rola chirurgii bariatrycznej

Patronat: Oddział Ślq̨ski Polskiego Towarzystwa Chirurgów Dziecięcych (PTChD)

\section{Miejsce operacji bariatrycznych w leczeniu otyłości w populacji pediatrycznej}

\author{
Bariatric surgery in the treatment of obesity \\ in the pediatric population \\ Paweł Matusik \\ Katedra i Klinika Pediatrii i Endokrynologii Dziecięcej, \\ Śląski Uniwersytet Medyczny w Katowicach
}

Obserwowany wzrost częstości występowania otyłości, w tym otyłości olbrzymiej i jej powikłań, wśród dzieci i młodzieży wiąże się z koniecznością doboru skutecznych metod terapeutycznych. Według dostępnych danych w grupie z największym zaawansowaniem choroby efektywność terapii zachowawczej jest znacząco niższa niż u pozostałych otyłych dzieci. Uzyskiwane efekty leczenia są najczęściej niewystarczające $\mathrm{w}$ zakresie procentowego spadku masy ciała i w większości przypadków przejściowe, ponieważ najważniejszą przeszkodą jest przewlekłe stosowanie zaleceń terapii behawioralnej. W związku z tym tematem wykładu będzie próba odpowiedzi na pytanie, w jaki sposób efektywnie i bezpiecznie wykorzystywać możliwości, jakie daje obecnie chirurgia bariatryczna w leczeniu otyłości olbrzymiej w populacji pediatrycznej. Zostaną przedstawione algorytmy wielodyscyplinarnego postępowania w zakresie kwalifikacji do zabiegu, doboru metody operacji oraz dalszej kontroli pooperacyjnej. Omówione zostaną także potencjalne wczesne i odległe powikłania oraz metody zapobiegania i minimalizacji ich skutków.

The observed increase in the incidence of obesity, including morbid obesity and its complications among children and adolescents, is associated with the need to select effective therapeutic methods. According to the available data, behavioural therapy in the group with the most advanced disease is significantly less effective than other obese children. The obtained treatment effects are usually inadequate in terms of percentage of weight loss and in most cases transient, because the most important obstacle is the chronic application of behavioral therapy recommendations. Therefore, the subject of the lecture will be an attempt to answer the question how to use effectively and safely the possibilities currently offered by bariatric surgery in the treatment of giant obesity in the pediatric population. The algorithms of multidisciplinary manage- 
ment in the field of surgery qualification, the choice of surgery method and further post-operative control will be presented. Also, potential early and distant complications as well as methods for preventing and minimizing their effects will be discussed.

\section{Bariatric surgery in adolescents - pre- and postoperative challenges}

\section{Marc Michalsky}

The Ohio State University, College of Medicine and Surgical Director, Center for Healthy Weight \& Nutrition at Nationwide Children's Hospital in Columbus, Ohio, U.S.

Dr. Marc Michalsky is Professor of Surgery and Pediatrics at The Ohio State University, College of Medicine and Surgical Director, Center for Healthy Weight \& Nutrition at Nationwide Children's Hospital in Columbus, Ohio, U.S. Professor Michalsky has served as a principle investigator on numerous studies including Teen-Longitudinal Assessment of Bariatric Surgery (Teen-LABS) study; a multicenter study investigating safety and health effects of adolescent bariatric surgery. Furthermore, he has assisted in development of clinical consensus guidelines for adolescent bariatric surgery and has served on various committees at American College of Surgeons, American Society of Metabolic and Bariatric Surgery and American Academy of Pediatrics. Dr. Michalsky will present a general overview of adolescent bariatric surgery and focus on general eligibility criteria, including recent updates of "best practice" guidelines as well as long-term effectiveness related to comorbid disease.

\section{Wyniki leczenia otyłości olbrzymiej u nastolatków - doświadczenia własne}

\author{
Therapy outcomes in the group of morbidly obese \\ adolescents - own experiences \\ Paweł Matusik ${ }^{1}$, Dominika Smyczek², Tomasz Koszutski \\ ${ }^{1}$ Katedra i Klinika Pediatrii i Endokrynologii Dziecięcej, \\ Śląski Uniwersytet Medyczny w Katowicach \\ ${ }^{2}$ Katedra i Klinika Chirurgii i Urologii Dziecięcej, \\ Śląski Uniwersytet Medyczny w Katowicach
}

Tematem prezentacji będzie przedstawienie wyników leczenia otyłości olbrzymiej u nastolatków, pacjentów Poradni Metabolicznej Górnośląskiego Centrum Zdrowia Dziecka w Katowicach, ze szczególnym uwzględnieniem 6 pacjentów, którzy w latach 2016-2018 zostali poddani laparoskopowej rękawowej resekcji żołądka. Omówione zostaną algorytmy postępowania na każdym etapie kwalifikacji, leczenia i prowadzenia pooperacyjnego.
The objective of the lecture will be presenting the results of treatment of morbid obesity in adolescents, patients of the Metabolic Out-Patient Clinic of the Upper Silesia Children's Health Center in Katowice, with special attention to 6 patients who in the years 20162018 underwent laparoscopic sleeve gastrectomy. The algorithms of conduct at each stage of qualification, treatment and post-operative management will be discussed.

\section{Psychologiczna ocena pacjentów otyłych w procesie kwalifikacji do operacji bariatrycznych}

\section{Psychological Assessment of Obese Patients in the Process of Qualification for Bariatric Surgeries \\ Agnieszka Dziurowicz-Kozłowska \\ BARIAMED, Warszawa}

Wstęp: Zmienne psychospołeczne i behawioralne odgrywają ważną rolę zarówno w powstawaniu, jak i leczeniu otyłości. Dlatego w procesie kwalifikacji pacjenta do zabiegu bariatrycznego konieczna jest ocena jego kondycji psychicznej. Pozwala ona na wczesną identyfikację ewentualnych przeciwwskazań oraz czynników potencjalnie zagrażających efektywności chirurgicznego leczenia otyłości.

Cel, materiał i metody: Wywiady kliniczne z blisko 500 dorosłymi pacjentami otyłymi zostały przeprowadzone przez psychologa zdrowia w okresie poprzedzającym operację. Ich analiza jakościowa pozwoliła na wyodrębnienie sześciu głównych obszarów, które powinny stać się przedmiotem oceny psychologicznej w procesie kwalifikacji pacjentów do operacji bariatrycznych.

Wyniki: Dokonując oceny psychologicznej kandydatów do operacji bariatrycznych, psycholog powinien skoncentrować się na następujących obszarach: 1) aktualny stan zdrowia psychicznego i historia psychiatryczna, 2) czas i okoliczności pojawienia się otyłości oraz historia dotychczasowych prób walki z nadwagą, 3) styl życia (dieta, aktywność fizyczna), nawyki żywieniowe i psychospołeczne funkcje jedzenia, 4) struktura i jakość sieci wsparcia społecznego, 5) wiedza, przekonania i oczekiwania pacjenta związane $\mathrm{z}$ operacją bariatryczną, 6) stopień przygotowania na istotną zmianę życiową i wyzwania będące wynikiem operacji bariatrycznej.

Wnioski: Przeprowadzenie oceny psychologicznej obejmującej powyższe obszary pozwala ocenić ich potencjalny wpływ na przebieg procesu chirurgicznego leczenia otyłości oraz zapewnić pacjentowi optymalne wsparcie psychologiczne w okresie przed-i pooperacyjnym. 
Introduction: Psychosocial and behavioural variables play an important role in both the development and treatment of obesity. Therefore, in the process of qualifying a patient for bariatric surgery, it is necessary to assess his/ her psychological state. Such evaluation is crucial for the identification of possible contraindications and early detection of factors potentially disturbing the effectiveness of surgical treatment of obesity.

Aim, material and methods: Clinical interviews with about 500 adult obese patients were conducted by a health psychologist in the presurgical period. The qualitative analysis of the interviews led to the identification of six major areas which should become the object of psychological evaluation in the process of qualifying patients for bariatric surgery.

Results: During psychological assessment of a candidates for bariatric surgeries, the psychologist needs to focus on: 1. Current psychological health state and psychiatric history. 2. Time and circumstances of the development of obesity, history of struggle with overweight. 3. Lifestyle (diet, physical activity), eating patterns and psychosocial functions of eating. 4. Structure and quality of the social support network. 5. Knowledge, beliefs and expectations regarding the bariatric procedure. 6 . The degree of preparation for a significant life change and challenges resulting from obesity surgery.

Conclusions: Conducting a psychological assessment comprising the above-mentioned areas allows to evaluate their potential influence on the process of surgical treatment of obesity and to provide optimal psychological support for the patient before and after the operation.

\section{SESJA IX: Prewencja i wspomaganie terapii żywieniowej jako obszary ścisłej współpracy lekarz - dietetyk}

\section{Czy suplementy wspomagające odchudzanie mogą być stosowane w leczeniu otyłości u dzieci?}

\section{Can dietary supplements be used in obesity therapy in children and adolescents?}

Agnieszka Zachurzok

Katedra i Klinika Pediatrii i Endokrynologii Dziecięcej, Śląski Uniwersytet Medyczny w Katowicach

Częstość otyłości na świecie osiągnęła rozmiary epidemii. W jej leczeniu ugruntowane miejsce mają zalecenia dietetyczne oraz aktywność fizyczna. Ze względu na częsty brak efektu w leczeniu otyłości stosuje się również chirurgię bariatryczną, a na całym świecie intensywnie bada się możliwości leczenia farmakologicznego. Ze względu na niski poziom efektywności leczenia poszukuje się również nowych, alternatywnych metod, sięgając po rozmaite substancje pochodzenia roślinnego i suplementy diety.

Suplementy diety uznano za środki spożywcze zawierające skoncentrowane substancje mogące wywierać pożądany efekt odżywczy, fizjologiczny czy terapeutyczny. W grupie suplementów wspomagających odchudzanie znajdują się preparaty zawierające składniki roślinne i różne ekstrakty roślinne, substancje zawierające niezbędne kwasy tłuszczowe, błonnik pokarmowy, witaminy i składniki mineralne. Prowadzone są również badania nad stosowaniem pro- i prebiotyków w leczeniu nadwagi i otyłości.

Należy pamiętać, że suplementy nie są lekami, a nadzór nad nimi sprawuje Główny Inspektor Sanitarny. Nie podlegają zatem tak restrykcyjnym przepisom, jeśli chodzi o bezpieczeństwo stosowania i rejestrację, jak leki. Wiele z nich jest nieprzebadanych i niezarejestrowanych we wspomaganiu leczenia otyłości u dzieci. Zamierzając zastosować suplement diety, należy mieć świadomość zawartej w nim substancji oraz możliwych skutków ubocznych. Jak również tego, że w olbrzymiej większości przypadków substancje zawarte w suplementach diety w sposób wystarczający i efektywny mogą być dostarczane w dobrze zbilansowanej, pełnowartościowej diecie. Aktualnie u dzieci jedynym składnikiem diety wymagającym dodatkowej suplementacji jest witamina $\mathrm{D}_{3}$. U dzieci z otyłością częściej aniżeli u dzieci z prawidłową masą będzie występował niedobór tej witaminy. Nie 
należy jednak oczekiwać, że suplementacja witaminą $\mathrm{D}_{3}$ będzie skutecznym lekarstwem na otyłość.

The incidence of obesity has reached the epidemic proportion. In its therapy diet and physical activity is the most important. Unfortunately, in many cases standard treatment is not sufficient and bariatric surgery is a treatment of choice. Moreover, very intensively many researches are being conducted to discover pharmacological treatment and alternative therapies with phytochemicals and dietary supplements.

Dietary supplements are food products containing concentrated substances that can provide desirable nutritive, physiological or therapeutic effect. The group of dietary supplements used in obesity consists of phytochemicals, essential fatty acids, fiber, vitamins and minerals. In recent years also pre and probiotics containing supplements are used in excessive weight therapy.

It is important to be aware that the dietary supplements are not drugs and the supervision on the market is hold by Main Sanitary Office. Their registration and application in no so restricted as medication. Many of supplements are not examined according to careful, restrictive standards and they are not registered in the therapy in children obesity. Before dietary supplement usage its composition and possible side effects should be known. However, most of the substances contained in dietary supplements are easily available from normal, full, well balanced diet.

In children only one substance should be supplemented - vitamin $\mathrm{D}_{3}$. Obese children and adolescents suffers from vitamin $\mathrm{D}_{3}$ deficiency significantly more often than normal weight children. However, vitamin $\mathrm{D}_{3}$ deficiency is not a cause of obesity and its supplementation is not sufficient for weight loss.

\section{Soki owocowe w diecie dzieci - ich wpływ na zdrowie}

\section{Fruit juices in children's diet - their impact on health}

Agnieszka Kozioł-Kozakowska

Pracownia Dietetyki Pediatrycznej, Klinika Pediatrii, Gastroenetrologii i Żywienia, Uniwersytet Jagielloński Collegium Medicum

Soki owocowe, tak jak owoce, mają wysoką gęstość odżywczą, wynikającą z dużej zawartości witamin i składników mineralnych w stosunku do wartości energetycznej. Sok pomarańczowy jest szczególnie bogatym źródłem witamin antyoksydacyjnych oraz fitozwiązków, takich jak karotenoidy (luteina, $\beta$-karoten i likopen) oraz polifenole, takie jak hesperydyna i naringinina, a ponieważ większość związków fenolowych znajduje się w skórce owocu, przemysłowe tłoczenie pozwala na przedostanie się większej ich ilości do soku. W badaniu HELENA ( $\mathrm{He}$ althy Lifestyle in Europe by Nutrition in Adolescence study) $\mathrm{u}$ europejskich nastolatków stwierdzono niedobór stężeń w osoczu: kwasu foliowego (15\%), witaminy D (15\%), $\beta$-karotenu (25\%) i witaminy E (5\%) (Diethelm, 2012). Tymczasem spożywanie 100-procentowego soku owocowego może pomóc w uzyskaniu dziennego zapotrzebowania na witaminę $C$, kwas foliowy, wapń, $\beta$-karoten i magnez. Jedna szklanka soku pomarańczowego pokrywa praktycznie dobowe zapotrzebowanie na witaminę C u dzieci i młodzieży oraz $20 \%$ dziennego zapotrzebowania na kwas foliowy. Zaobserwowano, że w diecie dzieci pijących soki owocowe jest mniej niezdrowych przekąsek dostarczających pustych kalorii. Wbrew powszechnej opinii soki owocowe nie zwiększają ryzyka otyłości u dzieci. Przegląd badań dotyczący soków owocowych i ich wpływu na masę ciała u dzieci nie potwierdza związku pomiędzy spożywaniem 100-procentowych soków owocowych a otyłością (Wang i wsp., 2012; Rampersaud i wsp., 2017). Odpowiednie spożycie owoców i warzyw ma znaczenie w profilaktyce wielu chorób przewlekłych niezakaźnych, obserwuje się silniejszy ochronny efekt w przypadku spożycia owoców niż warzyw. Instytut Żywności i Żywienia rekomenduje 1 szklankę 100-procentowego soku owocowego w ramach 1 porcji spożywanych owoców dziennie. Zgodnie $\mathrm{z}$ rekomendacjami soki powinny być spożywane wymiennie do 1 porcji owoców, a nie jako płyn do gaszenia pragnienia pity pomiędzy posiłkami. Również Amerykańska Akademia Pediatrii stwierdza, że 100-procentowy sok owocowy może stanowić element zdrowej diety dzieci w wieku powyżej 1. roku życia.

Fruit juices like fruits have a high nutritional density, resulting from a high content of vitamins and minerals with regard to their energy value. Especially orange juice is a rich source of antioxidant vitamins and phyto-compounds such as carotenoids (lutein, $\beta$-carotene and lycopene) and polyphenols such as hesperidin and naringinin, and because most of the phenolic compounds and carotenoids are found in the skin, industrial pressing allows for a greater amount of phytocompounds to pass into the juice. According to the Healthy Lifestyle in Europe by $\mathrm{Nu}$ trition in Adolescence study (HELENA, 2014), deficient concentrations were identified for plasma folate (15\%), vitamin D (15\%), $\beta$-carotene (25\%), and vitamin E (5\%) in European adolescents (Diethelm, 2012). Meanwhile, consuming $100 \%$ fruit juice can help in obtaining daily demand for vitamin $C$, folic acid, calcium, $\beta$-carotene and magnesium. One glass of orange juice covers the daily demand for vitamin $\mathrm{C}$ in children and adolescents and 20\% of the daily requirement for folic acid. It has been observed that in the diet of children who drink fruit juices 
there are less unhealthy snacks providing empty calories. Contrary to popular belief, fruit juices do not increase the risk of childhood obesity. The review of studies on fruit juices and their impact on body weight in children does not confirm the correlation between the consumption of $100 \%$ fruit juices and obesity (Wang et al., 2012; Rampersaud et al., 2017). Adequate fruit and vegetable consumption is important in the prevention of many chronic non-infectious diseases, with a stronger protective effect in the consumption of fruit than vegetables. The Polish National Institute of Food and Nutrition recommends 1 cup of $100 \%$ fruit juice as 1 portion of fruit consumed daily. According to the recommendations, juices should be consumed interchangeably with up to 1 portion of fruit and not as a liquid to quench your thirst between meals. American Academy of Pediatrics also states that $100 \%$ fruit juice can be part of a healthy diet for children over 1 year of age.

\section{Światowe rekomendacje z zakresu tworzenia skutecznych działań prewencyjnych w obszarze nadmiaru masy ciała u dzieci i młodzieży}

\section{Global recommendations for the creation of effective preventive measures in the area of excess body weight in children and adolescents}

Paulina Metelska ${ }^{1}$, Michał Brzeziński²

${ }^{1}$ Uniwersyteckie Centrum Kliniczne w Gdańsku ${ }^{2}$ Gdański Uniwersytet Medyczny

Wstęp: Obserwowany w ostatnich dekadach wyraźny wzrost częstości występowania otyłości wśród dorosłych, stwierdzany również w badaniach populacji wieku rozwojowego, postrzegany jest przez Światową Organizację Zdrowia (World Health Organization - WHO) w kategoriach epidemii. Większość konsekwencji zdrowotnych otyłości jest związana $\mathrm{z}$ czasem trwania zmian metabolicznych w organizmie, zatem otyłość rozpoznawana $\mathrm{w}$ dzieciństwie ma wiele konsekwencji zdrowotnych, ujawniających się w wieku dorosłym.

Materiał i metody: Światowa Organizacja Zdrowia, jako organizacja koncentrująca uwagę na szeroko pojętym zdrowiu, przygotowuje rekomendacje niezbędne do skutecznego przeciwdziałania NMC w populacji dziecięcej. W 2017 r. ukazał się raport Reducing childhood obesity in Poland by effective policies zawierający cały katalog opisujący praktyczne narzędzia i obszary działań, które muszą zostać podjęte, aby działania prewencyjne były efektywne.

Wyniki: Zalecenia WHO wyraźnie definiują obszary działań prewencyjnych. Na pierwszym plan wysuwają się promowanie zdrowego odżywiania i ograniczenie spożycia produktów o wysokiej zawartości cukru, soli oraz tłuszczu oraz promowanie aktywności fizycznej i ograniczenie siedzącego tryby życia. WHO wskazuje na konieczność podjęcia tych działań już na bardzo wczesnych etapach życia, rozpoczynając od świadomego przygotowaniu do poczęcia dziecka i w okresie ciąży, dalej poprzez wczesne dzieciństwo i okres nauki szkolnej. Zalecenia koncentrują uwagę również na populacji z NMC, która powinna zostać objęta multidyscyplinarnymi działaniami wspierającymi powrót do prawidłowej masy ciała.

Wnioski: Otyłość musi być rozpatrywana jako złożony problem, zależny od wielu czynników społecznych i środowiskowych. Działania prewencyjne muszą mieć charakter wielowymiarowy i trwały, realizowany przez cały cykl życia. Ujęcie działań w długofalową politykę wydaje się niezbędnym krokiem $\mathrm{w}$ tworzeniu skutecznych narzędzi prewencyjnych w obszarze nadmiaru masy ciała u dzieci i młodzieży.

Introduction: A clear increase in the incidence of obesity among adults observed in recent decades, also observed in studies of the population of developmental age, is perceived by the World Health Organization in terms of epidemics. Most of the health effects of obesity are related to the duration of metabolic changes in the body, so obesity diagnosed in childhood has many health consequences, manifested in adulthood.

Material and method: The World Health Organization, as a unit focusing on health in general, prepares the recommendations necessary to effectively counteract excess body weight in the child population. In 2017, the report entitled "Reducing childhood obesity in Poland by effective policies" was published, containing the entire catalog describing practical tools and areas of action that should be taken to ensure that preventive measures are effective.

Results: The WHO recommendations clearly define the areas of preventive action. The foreground is: promoting healthy nutrition and limiting the consumption of products with high sugar, salt and fat content, promoting physical activity and limiting sedentary lifestyle. The WHO points to the need to take these actions at a very early stage in life: from conscious preparation for the conception of the child and during pregnancy, up to early childhood and the school period. The recommendations also focus on the NMC population, which should be covered by multidisciplinary activities supporting the return to normal body weight.

Conclusions: Obesity should be considered as a complex problem, depending on many social and environmental factors. Preventive actions must be multidimensional and long-lasting, carried out throughout the life cycle. The summary of activities in long-term policy seems to be an indispensable step in creating effective 
preventive measures in the field of excessive body mass in children and adolescents.

\section{Wykorzystanie nowoczesnych technologii w profilaktyce i terapii otyłości dziecięcej}

The Use of Modern Technologies in the Prevention and Treatment of Childhood Obesity

Marek Jankowski ${ }^{1}$, Michał Brzeziński², Tomasz Kobus ${ }^{3}$

${ }^{1}$ Gdański Ośrodek Promocji Zdrowia

${ }^{2}$ Gdański Uniwersytet Medyczny

${ }^{3}$ eHealth Solutions sp. z o.o.

Wstęp: Wraz z rozwojem technologii teleinformatycznych zwiększa się ich wykorzystanie w działaniach na rzecz zdrowia. Strategie dotyczące profilaktyki otyłości coraz częściej uwzględniają interwencje behawioralne, których realizacja odbywa się z wykorzystaniem nowych technologii i form komunikacji. Lokalne działania $\mathrm{z}$ użyciem takich narzędzi realizowane w ramach Gdańskiego Modelu Promocji Zdrowia stanowią jeden z przykładów promowania zdrowego stylu życia w celu umacniania potencjału zdrowotnego młodej populacji mieszkańców miasta.

Materiał i metody: Wybrane przykłady działań prowadzonych $\mathrm{z}$ użyciem platform informatycznych i aplikacji mobilnych pochodzą z programów profilaktycznych i terapeutycznych realizowanych przez Gdański Ośrodek Promocji Zdrowia oraz Uniwersyteckie Centrum Kliniczne w Gdańsku. Prezentowane narzędzia IT wspierają programy: „Gdańsk - jemy zdrowo”, „Kierunek Zdrowie”, „6-10-14 dla Zdrowia”.

Wyniki: Wykorzystywanie narzędzi IT w ramach Gdańskiego Modelu Promocji Zdrowia zwiększające efektywność działań leczniczych i profilaktycznych może być jedną z przyczyn spadku odsetka dzieci z nadwagą i otyłością w okresie 5 lat, który zaobserwowano w populacji 9-11-letnich gdańskich dzieci.

Wnioski: Narzędzia telekomunikacyjne usprawniające działania i zwiększające efektywność interwencji behawioralnych stanowią cenny zasób wykorzystywany $\mathrm{w}$ działaniach profilaktycznych i terapeutycznych w obszarze chorób cywilizacyjnych. Wykorzystywanie nowych technologii w promocji zdrowia, profilaktyce chorób i medycynie naprawczej wymaga monitorowania ich skuteczności.

Introduction: With the development of ICT technologies their use in pro-health activities is becoming increasingly common. Recently, the strategies for obesity prevention tend to include behavioral interventions, which are implemented with the use of modern technolo- gies and new forms of communication. Local actions with the use of such tools, introduced as part of the Gdańsk Model for Health Promotion, are one of the examples of promoting a healthy lifestyle in order to strengthen the health potential of the youth population in the city.

Material and method: Selected examples of activities performed with the use of IT platforms and mobile apps originate from preventive and therapeutic programs implemented by the Gdańsk Center for Health Promotion and the University Clinical Center in Gdańsk. The presented IT tools are supported by the following programs: "Gdańsk - We Eat Healthy", "Direction Health”, "6-10-14 for Health".

Results: The use of IT tools within the Gdańsk Model for Health Promotion which improve the effectiveness of therapeutic and preventive measures may be one of the reasons for the decrease in the percentage of overweight and obese children over the period of 5 years, which was observed among children aged 9-11 in Gdańsk.

Conclusions: Telecommunication tools which streamline activities and improve the efficiency of behavioral interventions constitute a valuable resource used in preventive and therapeutic activities in the field of civilization diseases. The use of modern technologies in health promotion, illness prevention and corrective medicine requires monitoring their effectiveness. 


\section{SESJA PLAKATOWA}

\section{P01 \\ Analiza zaburzeń metabolicznych u dzieci
i młodzieży z nadwagą i otyłością}

Analysis of metabolic disturbances among children and youth with overweight and obesity

Magdalena Kowaleczko ${ }^{1}$, Monika Luboch-Furmańczyk ${ }^{1}$, Małgorzata Myśliwiec²

${ }^{1}$ Klinika Pediatrii, Diabetologii i Endokrynologii, Uniwersyteckie Centrum Kliniczne w Gdańsku

${ }^{2}$ Katedra i Klinika Pediatrii, Diabetologii i Endokrynologii, Gdański Uniwersytet Medyczny

Wstęp: Nadwaga i otyłość stanowią coraz poważniejszy, narastający problem w populacji wieku rozwojowego w Polsce. Pożądane byłoby opracowanie prostych nieinwazyjnych metod wykrywających najbardziej obciążoną grupę dzieci i młodzieży z otyłością w celu wyselekcjonowania tych, u których rozwinęły się już powikłania metaboliczne.

Cel pracy: Analiza występowania poszczególnych składowych zespołu metabolicznego oraz korelacji masy i budowy ciała $\mathrm{z}$ nieprawidłowościami w badaniach laboratoryjnych u pacjentów $\mathrm{z}$ nadmierną masą ciała hospitalizowanych w Klinice Pediatrii, Diabetologii i Endokrynologii UCK w Gdańsku.

Materiał i metody: Analizie poddano dane dotyczące losowo wybranych 83 pacjentów $\mathrm{z}$ nadwagą lub otyłością hospitalizowanych w okresie od grudnia 2016 do grudnia 2017 r. Badanie miało charakter obserwacyjny, retrospektywny. Zebrane dane pochodziły $\mathrm{z}$ dokumentacji medycznej.

Wyniki: Analizie poddano dokumentację 83 pacjentów w wieku 12,5 \pm 3 lat, 52 płci żeńskiej i 31 płci męskiej. U wszystkich pacjentów pozycja centylowa wartości BMI odniesionej do wieku spełniała kryteria rozpoznania nadwagi lub otyłości. U 79 pacjentów (95\%) wartość współczynnika talia/wzrost (WHtR) była wyższa niż 0,5. Średnia oraz mediana wartości WHtR w badanej grupie wynosiła 0,59. U 1 pacjenta stwierdzono nadczynność tarczycy, wobec czego jego dane nie były wliczane do dalszych statystyk. Jeden pacjent był leczony z powodu nadciśnienia tętniczego. Zaburzenia lipidowe zaobserwowano u $62 \%$ pacjentów. Zaburzenia gospodarki węglowodanowej stwierdzono u $8 \%$ pacjentów. W badaniu ultrasonograficznym u 63\% pacjentów opisano hepatomegalię, u 40\% cechy stłuszczenia wątroby. Średnie stężenie cholesterolu całkowitego w badanej grupie wynosiło $174 \pm 31 \mathrm{mg} / \mathrm{dl}$, mediana $172 \mathrm{mg} / \mathrm{dl}$; średnie stężenie frakcji LDL - $108 \pm 28 \mathrm{mg} / \mathrm{dl}$, HDL - $48 \pm 28 \mathrm{mg} / \mathrm{dl}$, trój- glicerydów - $98 \pm 11 \mathrm{mg} / \mathrm{dl}$. Zaobserwowano istotną statystycznie, ujemną korelację między WHtR a stężeniem frakcji HDL cholesterolu $(r=-0,36, p=0,004)$ oraz dodatnią korelację między WHtR a stężeniem trójglicerydów $(r=0,25, p=0,021)$.

Wnioski: WHtR może być prostym, łatwym do wykorzystania w gabinetach POZ i oddziałach szpitalnych predyktorem zaburzeń gospodarki lipidowej u dzieci i młodzieży. U każdego pacjenta z nieprawidłowym stosunkiem talia-wzrost konieczne jest poszerzenie diagnostyki o laboratoryjną ocenę lipidogramu w celu wczesnego wykrycia i leczenia dyslipidemii.

Introduction: Overweight and obesity among children and youth constitute a serious and increasing problem in Poland. It is necessary to distinguish a group of obese children, who are the most exposed to metabolic complications, with non-invasive diagnostic tools.

Objective: The aim of the study was to analyse the occurrence of components of the metabolic syndrome and correlation between body weight and physique with abnormalities in laboratory tests in the group of overweight or obese patients.

Material and methods: Data of 83 random patients hospitalised in Department of Pediatrics, Diabetology and Endocrinology of University Clinical Center in Gdańsk between December 2016 and December 2017 was analysed retrospectively.

Results: Data of 83 random patients: 52 female and 31 male, aged $12.5 \pm 3$ years was analysed. All patients were overweight or obese (BMI > $90 \mathrm{cc}$ ). Waist/height index (WHtR) was higher than 0,5 in 79 cases (95\%). Average and median WHtR was 0,59 . Due to the decompensated hyperthyroidism in one patient, his results were not analysed. One patient was treated for hypertension. In studied group, $62 \%$ of patients had lipid disorders and $8 \%$ presented carbohydrate disorders. In $63 \%$ of cases in ultrasound abdomen examination hepatomegaly was found, in $40 \%$ hepatosteatosis. Average total cholesterol level was $174 \pm 31 \mathrm{mg} / \mathrm{dl}$, median $172 \mathrm{mg} / \mathrm{dl}$; average LDL level was $108 \pm 28 \mathrm{mg} / \mathrm{dl}$, HDL $-48 \pm 28 \mathrm{mg} / \mathrm{dl}$, triglycerides $-98 \pm 11 \mathrm{mg} / \mathrm{dl}$. A statistically significant negative correlation between WHtR and HDL level was observed $(r=-0.36, p=0.004)$. Moreover, weak positive correlation between WHtR and triglycerides concentration was observed $(r=0.25, p=0.021)$.

Conclusions: Waist-to-height ratio is a simple and easy-to-use indicator of lipid disorders in children that can be used in pediatric wards and in general practice. Every patient with abnormal WHtR result should be tested for dyslipidemia in order to introduce early treatment if required. 
P02

\section{Czynniki prognostyczne otyłości podwzgórzowej po leczeniu czaszkogardlaka}

\section{Prognostic factors of hypothalamic obesity after childhood-onset craniopharyngioma}

Elżbieta Moszczyńska ${ }^{1}$ Agnieszka Bogusz ${ }^{1}$, Mieczysław Szalecki ${ }^{1,2}$

${ }^{1}$ Klinika Endokrynologii i Diabetologii,

Instytut „Pomnik - Centrum Zdrowia Dziecka” w Warszawie

${ }^{2}$ Wydział Lekarski i Nauk o Zdrowiu,

Uniwersytet im. Jana Kochanowskiego w Kielcach

Wstęp: Otyłość podwzgórzowa po leczeniu czaszkogardlaka występuje u 50-80\% pacjentów. W momencie rozpoznania jest obserwowana u $12-30 \%$ chorych oraz występuje częściej w przypadku rozległego przedoperacyjnego uszkodzenia podwzgórza. Po 3-miesięcznej obserwacji po leczeniu dotyczy $57 \%$ pacjentów, po rocznej - $62 \%$, a po 5-letniej - 58\%. Do czynników patogenetycznych otyłości podwzgórzowej należą: hiperfagia, zaburzenia układu autonomicznego (obniżony tonus układu współczulnego oraz podwyższony przywspółczulnego), obniżona aktywność fizyczna, niedobory hormonów przysadkowych (GH, TSH, LH, FSH), hiperinsulinizm, hiperleptynemia oraz obniżone stężenie melatoniny.

Cel: Analiza czynników prognostycznych otyłości podwzgórzowej po leczeniu czaszkogardlaka.

Materiał i metody: Retrospektywna analiza 100 pacjentów leczonych z powodu czaszkogardlaka w IP-CZD w latach 1998-2012. U wszystkich pacjentów rozpoznano typ szkliwiakowy czaszkogardlaka. Średni czas obserwacji wynosił 9,07 roku (0,47-19,28 roku).

Wyniki: Do istotnych czynników prognostycznych otyłości należały: wielkość guza $\geq 4 \mathrm{~cm}$, nadsiodłowa lokalizacja, naciekanie III komory, uszkodzenie podwzgórza (2. stopień zajęcia podwzgórza w klasyfikacji Pugeta), kraniotomia, częściowa resekcja guza oraz wznowa guza $\mathrm{w}$ porównaniu $\mathrm{z}$ progresją. $\mathrm{Z}$ objawów podmiotowych za istotne statystycznie uznano: bóle głowy $(p=0,010)$ oraz zaburzenia łaknienia $(p=0,003)$, a na granicy istotności statystycznej - zaburzenia pamięci obserwowane po leczeniu $(p=0,05)$. Wykazano istotną statystycznie korelacje między otyłością a immunoekspresją włókien Rosenthala $(p=0,010)$ oraz centralną przedoperacyjną niedoczynnością tarczycy $(p=0,012)$. Nie wykazano takiego związku z niedoborem w zakresie GH, ACTH, LH/ FSH czy hiperprolaktynemią.

Wnioski: Jednym z kluczowych powikłań po leczeniu czaszkogardlaka była otyłość, istotnie skorelowana ze średnicą i położeniem guza (nadsiodłowa lokalizacja, uszkodzenie struktur podwzgórza, naciekanie III komo- ry), BMI SDS w momencie diagnozy, częściowa resekcja guza oraz obecność włókien Rosenthala w badaniu histopatologicznym.

Introduction: Hypothalamic obesity after craniopharyngioma (CP) treatment occurs in $50-80 \%$ of patients. At the time of diagnosis, it is observed in $12-30 \%$ of patients and is more common in the case of extensive pre-operative damage to the hypothalamus. After the 3-month post-treatment observation relates to $57 \%$ of the patients, after one year $-62 \%$ and after 5 years $58 \%$. Pathogenic factors of hypothalamic obesity include: hyperphagia, autonomic nervous system disorders (decreased sympathetic nervous system tone and elevated parasympathetic), reduced physical activity, pituitary hormone deficiencies ( $\mathrm{GH}, \mathrm{TSH}, \mathrm{LH}, \mathrm{FSH})$, hyperinsulinism, hyperleptinemia and decreased melatonin concentration.

Objective: Analysis of prognostic factors of hypothalamic obesity after craniopharyngioma.

Material and methods: A retrospective analysis of 100 patients diagnosed with craniopharyngioma in IPCZD in the years 1998-2012. In all patients, the adamantinomatous type of the CP was diagnosed. Statistically significant correlations between obesity and immunoexpression of Rosenthal's fibers $(p=0.010)$ and central pre-operative hypothyroidism were found $(p=0.012)$.

Results: Significant prognostic factors of obesity included: tumor size $\geq 4 \mathrm{~cm}$, suprasellar localization, involving the third ventricle, hypothalamic involvement (grade II lesions in the Puget classification), craniotomy, partial tumor resection and tumor recurrence as compared to progression. The following symptoms were considered statistically significant: headache $(p=0.010)$ and appetite disorders $(p=0.003)$, and on the border of statistical significance - memory impairment observed after treatment $(p=0.05)$. It revealed no compound deficient in terms of GH, ACTH, LH/FSH or hyperprolactinemia.

Conclusions: One of the key complications after craniopharyngioma treatment was obesity significantly correlated with the diameter and location of the tumor (suprasellar localization, damage to the hypothalamus structures, involving the third ventricle), BMI SDS at the time of diagnosis, partial tumor resection and presence of Rosenthal fibers in histopathological examination. 


\section{P03}

\section{Model regresji wieloczynnikowej w ocenie masy tkanki tłuszczowej u dzieci metodą bioimpedancji i densytometryczną}

\section{Differences in total and truncal body fat mass in children using DXA and BIA method - multifactorial regression model}

Elżbieta Jakubowska-Pietkiewicz ${ }^{1}$, Agnieszka Szadkowska², Wojciech Fendler ${ }^{3}$

${ }^{1}$ Klinika Propedeutyki Pediatrii i Chorób Metabolicznych Kości, Uniwersytet Medyczny w Łodzi

${ }^{2}$ Klinika Pediatrii, Onkologii, Hematologii i Diabetologii, Uniwersytet Medyczny w Łodzi

${ }^{3}$ Zakład Biostatystyki i Medycyny Translacyjnej, Uniwersytet Medyczny w Łodzi

Wstęp: Densytometria, oceniająca precyzyjnie całkowitą i odcinkową masę tkanki tłuszczowej, jest badaniem kosztownym i mało dostępnym. Znacznie tańsza i coraz powszechniej stosowana impedancja bioelektryczna jest mniej dokładna w ocenie całkowitej i odcinkowej zawartości tkanki tłuszczowej.

Cel: Celem pracy było opracowanie modelu, który zmniejszałby błąd pomiaru uzyskany metodą bioimpedancji w stosunku do wyniku densytometrycznego w ocenie całkowitej i odcinkowej zawartości masy tłuszczowej u dzieci.

Material i metody: Badania przeprowadzono u 56 dzieci w wieku 6-18 lat. U wszystkich wykonano badanie densytometryczne metodą absorpcjometrii promieniowania rentgenowskiego o podwójnej energii (DXA), oceniając całkowitą masę tkanki tłuszczowej $(\%, g)$ oraz procent zawartość tłuszczu na kończynach i tułowiu. Analizy impedancji bioelektrycznej (BIA) dokonano przy użyciu wagi firmy Tanita $\mathrm{z}$ wbudowanym systemem ośmioelektrodowym, biorąc pod uwagę takie same parametry badania.

Wyniki: Bioimpedancja zaniżała względem densytometrii wartości procentowej zawartości całkowitej tkanki tłuszczowej oraz na tułowiu ( $p<0,0001)$. Średnia procentowa różnica pomiędzy wartościami wskazanymi przez densytometrię a bioimpedancję wynosiła 14,23 $\pm 33,44 \%$ (mediana 5,30; IQR 1,35-10,9). Mediana bezwzględnego, średniego błędu procentowego (mean absolute percentage error - MAPE) wynosiła 18,55 (Me 28,13; IQR 18,47$38,88 \%)$. Współczynnik determinacji $\left(R^{2}\right)$ prostej regresji liniowej bioimpedancji wobec densytometrii wynosił $0,83(p<0,0001)$. Model wieloczynnikowy znacznie poprawiał precyzję oszacowania $(p<0,0001)$ - średni błąd oszacowania wynosił $6,11 \pm 29,30(\mathrm{Me}-0,04$; IQR $-7,97$ do 10,96), a mediana MAPE równała się 18,54 $\pm 23,38$ (Me 9,89; IQR 4,21-23,37). Ostateczny model predykcji opierał się na parametrach procentowej całkowitej zawar- tości tłuszczu, procentowej zawartości tłuszczu na prawej i lewej kończynie dolnej oraz na kończynie górnej lewej.

Wnioski: Zastosowanie modelu regresji wieloczynnikowej zmniejsza różnice pomiędzy wynikami uzyskanymi w badaniu densytometrycznym a impedancją bioelektryczną w ocenie całkowitej i odcinkowej zawartości tkanki tłuszczowej u dzieci, poprawiając precyzję pomiaru.

Objective: The objective of the study was to establish a model that would reduce the bioimpedance measurement error as compared with the densitometric result, in terms of total and segmental fatty tissue content in children.

Material and methods: The study was conducted on 56 children aged 6-18. All subjects underwent a densitometry examination (DXA), to assess total fatty tissue mass $(\%, g)$ and $\%$ fatty tissue on limbs and trunk. The bioelectric impedance (BIA) analyses were performed using a Tanita scale, considering identical measurement parameters.

Results: The average percent deviation between values obtained with densitometry and bioimpedance was $14.23 \pm 33.44 \%$ (median 5.30; IQR 1.35-10.9). The median of the mean absolute percentage error (MAPE) was 18.55 (Me 28.13; IQR 18.47-38.88\%). The coefficient of determination (R2) of the simple linear regression of bioimpedance, as compared with densitometry, was 0.83 ( $p<$ $0.0001)$. The multi-factorial model significantly improved the estimation accuracy $(p<0.0001)$ - the mean estimation error was $6.11 \pm 29.30$ ( $\mathrm{Me}-0.04 ; \mathrm{IQR}-7.97$ through 10.96 ), while the MAPE median was $18.54 \pm 23.38$ (Me 9.89; IQR 4.21-23.37). The final prediction model was based on \% parameters of overall fatty tissue content, $\%$ fatty tissue on the right and left lower limb, and on the left upper limb.

Conclusions: Use of a multi-factorial regression model reduces the differences between results obtained using densitometry and those achieved with bioelectric impedance, in terms of overall and segmental fatty tissue content evaluation in children, improving the measurement accuracy. 
P04

\section{Ocena częstości występowania insulinooporności u dzieci i młodzieży z rozpoznaną otyłością}

\section{Evaluation of insulin resistance in children and adolescents with obesity}

Dominika Lemańczyk, Alicja Skrobot, Małgorzata Myśliwiec, Ada Przygocka-Pieniążek

Oddział Diabetologii Dziecięcej, Klinika Pediatrii, Diabetologii i Endokrynologii, Uniwersyteckie Centrum Kliniczne w Gdańsku

Wstęp: Insulinooporność jest stanem obniżonej wrażliwości tkanek na działanie insuliny. Częstość jej występowania niepokojąco wzrasta. Obecnie w populacji pediatrycznej występuje ona na poziomie $11,5 \%$. Jednym z głównych czynników uważanych za inicjujące rozwój insulinooporności jest otyłość.

Material i metody: Retrospektywnie przeanalizowano historie chorób pacjentów hospitalizowanych w Klinice Pediatrii, Diabetologii i Endokrynologii z powodu otyłości. Badaniem objęto 72 pacjentów w wieku od 5 do 18 lat $\mathrm{z}$ rozpoznaną otyłością (BMI $>95 \mathrm{cc}$ ). U wszystkich pacjentów wykonano test doustnego obciążenia glukozą, z oznaczeniem stężenia glukozy i insuliny. Stężenie insuliny na czczo $>15 \mu \mathrm{U} / \mathrm{ml}$, w 120 . minucie testu $>75 \mu \mathrm{U} /$ $\mathrm{ml}$ lub $>150 \mu \mathrm{U} / \mathrm{ml}$ w którymkolwiek punkcie testu zdefiniowano jako insulinooporność.

Wyniki: W badanej grupie spośród 72 (100\%) pacjentów insulinooporność stwierdzono u 42 (58\%). U 30 pacjentów (42\%) stężenia insuliny w teście były prawidłowe.

Wnioski: Otyłość stanowi istotny czynnik rozwoju insulinooporności. Profilaktyka występowania nadwagi i otyłości wśród pacjentów pediatrycznych może zapobiec rozwojowi insulinooporności i jej powikłań.

Finansowane ze środków statutowych Kliniki Pediatrii, Diabetologii i Endokrynologii, Uniwersyteckiego Centrum Klinicznego w Gdańsku.

Introduction: The insulin resistance (IR) is a state in which tissues have lowered insulin sensitivity. In pediatric population it is $11.5 \%$ nowadays, but the incidence is alarmingly increasing every year. One of the most important factors leading to promotion of IR is obesity.

Material and methods: The retrospective analysis of medical histories of obese patients, hospitalized in Pediatrics, Diabetology and Endocrinology Clinic, Pediatrics, Diabetology and Endocrinology Clinic, University Clinical Center of Gdansk. 72 histories were analyzed, of patients between 5 and 18 years old, with diagnosed obesity (BMI over 95 percentile). In all patients oral glucose tolerance test was conducted, with glucose and insulin assessment. We defined the IR as fasting insulin level over
$15 \mu \mathrm{U} / \mathrm{ml}$, over $75 \mu \mathrm{U} / \mathrm{ml}$ in 120 minute of the test or over $150 \mu \mathrm{U} / \mathrm{ml}$ at any other time-point of test.

Results: Of 72 patients' analyzed, 42 (58\%) were diagnosed with insulin resistance. The remaining 30 patients (42\%) had proper insulin levels.

Conclusions: Obesity is a very important factor in developing insulin resistance. The prevention of overweight and obesity in pediatric population is therefore a way of prevention of insulin resistance and its complications.

Financed from statutory measures of Pediatrics, Diabetology and Endocrinology Clinic, University Clinical Center of Gdansk.

\section{P05 \\ Zmuszanie do jedzenia jako forma przemocy $w$ rodzinie}

\section{Forced feeding as a form of family violence}

Ada Przygocka-Pieniążek, Dominika Lemańczyk, Małgorzata Myśliwiec

Oddział Diabetologii Dziecięcej, Klinika Pediatrii, Diabetologii i Endokrynologii, Uniwersyteckie Centrum Kliniczne w Gdańsku

Wstęp: Otyłość dzieci i młodzieży jest narastającym problemem społeczno-zdrowotnym. Opiekunowie odgrywają kluczową rolę $\mathrm{w}$ procesie leczenia, niestety nie zawsze jest to rola pozytywna. Znaczącym problemem jest brak wsparcia dziecka przez rodziców, jednak w skrajnych przypadkach może dochodzić do niszczenia wysiłków dziecka i zespołu leczącego.

Materiał i metody: Analiza dostępnych wyników badań laboratoryjnych, obrazowych i dynamicznych oraz obserwacji pacjenta i jego rodziców przez personel medyczny, zebranych podczas trzykrotnej hospitalizacji 8-letniego pacjenta w Klinice Pediatrii, Diabetologii i Endokrynologii Dziecięcej.

Wyniki: Podczas pierwszej hospitalizacji pacjenta $\mathrm{z}$ powodu otyłości matka pacjenta wydawała się osobą troskliwą i gotową do współpracy z zespołem leczącym. Cztery miesiące później stan pacjenta znacznie się pogorszył, masa ciała wzrosła z 51,7 kg do 77,2 kg, a BMI z 33,9 do $48,25 \mathrm{~kg} / \mathrm{m}^{2}$. Pacjenta przyjęto do Kliniki z powodu niewydolności oddechowo-krążeniowej. Matka negowała nieprzestrzeganie zaleceń lekarskich. Podczas pobytu na oddziale masa ciała dziecka sukcesywnie spadała, a stan ogólny poprawiał się. Rodzic deprecjonował wysiłki dziecka i podważał jego sukcesy, których celem było osiągnięcie prawidłowej masy ciała. Matka obawiała się, że dieta ułożona przez dietetyka klinicznego jest niewłaściwa i może doprowadzić do zagłodzenia pacjenta. Podczas pobytu na oddziale matka izolowała dziecko od rówieśników, a osoby dorosłe usiłowała nastawić nega- 
tywnie wobec dziecka, sugerując zaburzenia psychiczne i skłonność do konfabulacji. Dzięki dociekliwości personelu medycznego doszło do konfrontacji z matką podczas siłowego karmienia dziecka $\mathrm{w}$ toalecie. Wdrożono postępowanie prawne, złożono zawiadomienie do Sądu Rejonowego oraz założono Niebieską Kartę.

Wnioski: Diagnostyka pacjenta podczas kilkudniowej hospitalizacji na oddziale umożliwia lepsze zapoznanie się z przyczynami otyłości pacjenta. Tworzenie zespołów leczniczych składających się z lekarza, psychologa, dietetyka umożliwia skuteczną i efektywną pracę.

Introduction: The obesity of children and adolescents is a rising social and healthcare problem. The children caretakers have a crucial role in the process of treatment, yet not always it is a positive role. Lack of support is a significant problem itself, but in utmost situation it evolves into obstruction of patient's and therapeutic team's efforts.

Objective: To present a case and start a discussion on significance of building a therapeutic team.

Material and methods: The analysis of available laboratory tests results, imaging and physical examinations, and medical staff observations, collected during 3 hospitalizations of 8 years old S.P. in Pediatrics, Diabetology and Endocrinology Clinic, Medical University of Gdansk. During first, one day, patient's hospitalization, due to obesity, his mother seemed to be caring and ready to cooperate. 4 months later, his general condition worsened a lot he was in danger of circulatory-respiratory failure, as his body mass increased from $51.7 \mathrm{~kg}$ to $77.2 \mathrm{~kg}$, BMI from $33.9 \mathrm{~kg} / \mathrm{m}^{2}$ to $48.25 \mathrm{~kg} / \mathrm{m}^{2}$. Mother was assuring she went by doctors' and dietician's recommendations. During hospitalization patient's weight gradually decreased and his general condition got better. Although patients was motivated and enjoyed his success, mother kept on repeating that he would gain weight again after leaving the ward, so his efforts are meaningless. She was expressing concern, that diet arranged by clinical dietician is incorrect and would lead to child starvation. During the stay, mother was isolating child from its peers, and tried to convince adults that children has signs of mental disorders and is prone to confabulation.

Results: Through personnel's investigation, other was caught in the act of force feeding child inside bathroom. Legal procedure was started, and notification of family violence was send to court.

Conclusions: Few days hospitalizations allow to improve insight in causes of patient's obesity and in his family situations. Therapeutic teams build from doctor, dietician, psychologist and social assistance provide more versatile and effective therapy.

\section{P06}

Trzynastoletnia dziewczynka

z hiperglikemią i otyłością na oddziale anestezjologii i intensywnej terapii dla dzieci - opis przypadku

\section{A 13-year-old girl with hyperglycemia and obesity in the anesthesiology and intensive care unit for children - a case report}

Michał Czapla, Anna Felińczak, Piotr Karniej

Zakład Organizacji i Zarządzania, Katedra Zdrowia Publicznego, Wydział Nauk o Zdrowiu, Uniwersytet Medyczny we Wrocławiu

Wstęp: U pacjentów z cukrzycą może dochodzić do nagłych zmian poziomu stężenia glukozy. Prawidłowy jej poziom powinien oscylować w granicach 70-99 mg/ dl na czczo. Wysokie stężenie glukozy (hiperglikemia) może powodować zmiany metaboliczne, które nieleczone mogą doprowadzić nawet do zgonu pacjenta. Najczęstszą postacią cukrzycy u dzieci i młodzieży jest cukrzyca typu 1. Jednakże coraz częściej u dzieci zostaje rozpoznana cukrzyca typu 2.

Opis przypadku: Trzynastoletnia dziewczynka została przyjęta na oddział anestezjologii i intensywnej terapii dla dzieci z oddziału pediatrii z powodu hiperglikemii, zaburzeń świadomości i narastającej niewydolności oddechowej. W chwili przyjęcia pacjentka była przytomna, podsypiająca. Wybudzana nawiązywała prosty kontakt. Dziewczynka oddychała samodzielnie, jednakże z zauważalnym wysiłkiem oddechowym i hipowentylacją. Akcja serca miarowa 130/minutę. W badaniu gazometrycznym cechy kwasicy oddechowej, m.in. obniżone $\mathrm{pH}$ krwi oraz $\mathrm{pCO}_{2} 96 \mathrm{~mm} \mathrm{Hg}$. W badaniach laboratoryjnych stężenie glukozy wynosiło $647 \mathrm{mg} / \mathrm{dl}$, a sodu $161 \mathrm{mEq} / \mathrm{l}$. Masa ciała pacjentki w chwili przyjęcia wynosiła około $120 \mathrm{~kg}$. $\mathrm{Z}$ wywiadu wiadomo, że dziewczynka nadmiernie przybierała na wadze od 5. roku życia. Pacjentka początkowo była wspomagana oddechowo metodą NIV, następnie została zaintubowana i wentylowana mechanicznie. W trybie leczenia stopniowo normalizowały się parametry metaboliczne oraz infekcyjne. W 6. dobie dziewczynka została ekstubowana i okresowo wspomagana nieinwazyjnymi metodami, m.in. metodą NIV w trybie nocnym. Podczas pobytu zaobserwowano u pacjentki zaburzenia stanu emocjonalnego i brak kontroli czynności fizjologicznej. Podczas konsultacji psychiatrycznej rozpoznano depresję i wdrożono odpowiednie leczenie. Personel oddziału prowadził edukację żywieniową i zdrowotną. Po konsultacji dietetycznej wprowadzono dietę cukrzycową. Dziecko zostało poddane intensywnej rehabilitacji. Pacjentkę po 3-tygodniowym pobycie na ww. oddziale w stanie stabilnym przekazano do Kliniki Endokrynologii i Diabetologii Wieku Rozwojowego. Masa ciała przy 
wypisie wynosiła $110 \mathrm{~kg}$. Waga dziecka po 3 miesiącach od hospitalizacji wynosiła $89 \mathrm{~kg}$.

Wnioski: Przedstawiony przypadek 13-letniej pacjentki, u której rozpoznano cukrzycę typu 2, potwierdza, że istnieje ryzyko występowania tego typu cukrzycy u pacjentów pediatrycznych z otyłością. Zadaniem lekarzy i personelu medycznego jest wczesne rozpoznanie zespołu metabolicznego oraz wdrożenie leczenia, m.in. środkami niefarmakologicznymi. Może to pozwolić na uniknięcie rozwoju cukrzycy typu 2 i jej groźnych powikłań.

Introduction: Patients with diabetes may experience sudden changes in glucose levels. Normal glucose level in blood should oscillate between $70-99 \mathrm{mg} / \mathrm{dl}$. High glucose (hyperglycemia) can lead to metabolic changes which, if not treated, can lead to death of the patient. The most common form is type 2 diabetes.

Case report: 13-year-old girl was admitted to department of anesthesia and intensive care from pediatric unit with hyperglycemia, consciousness disorders and increasing respiratory failure. A patient was conscious, sleepy. When awake she has basic contact. The girl breathed by herself, however, with noticeable effore and hypoventilation. Hearts action were 130 per minute. The gasometric test showed the features of respiratory acidosis include decreased blood $\mathrm{pH}$ and $\mathrm{pCO}_{2} 96 \mathrm{~mm} \mathrm{Hg}$. In laboratory tests, the glucose level was $647 \mathrm{mg} / \mathrm{dl}$ and sodium $161 \mathrm{mEq} / \mathrm{l}$. The patient's weight at the time of admission was around $120 \mathrm{~kg}$. From the interview it is known that the girl has overgrown weight since she was 5 years old. The patient was initially breath-assisted by the NIV method, then was intubated and mechanically ventilated. Metabolic and infectious parameters gradually normalized in the treatment mode. During hospital care, the patient was diagnosed with an emotional state disorder and no control of the physiological function. During the psychiatric consultation was diagnosed with depression. Appropriate treatment was implemented. The department's staff educated patient in diet and lifestyle modification. After consultation with a dietician, a diabetic diet was introduced. The child underwent intensive rehabilitation. After a 3-week stay stable patient was transferred to the Department of Endocrinology and Diabetology for children. Weight at discharge was $110 \mathrm{~kg}$. The child's weight after 3 months from hospitalization is $89 \mathrm{~kg}$.

Conclusions: The presented case of a 13-year-old patient diagnosed with type 2 diabetes confirms that there is a risk of this type of diabetes in paediatric patients with obesity. The task of physicians and medical personnel is to early diagnose of the metabolic syndrome and the implementation of treatment, also non-pharmacological. This may prevent the development of type 2 diabetes in children and its dangerous complications.

\section{P07 Dziecko otyłe - chore czy krzywdzone?}

\author{
Obese child - sick or abused? \\ Iga Kapczuk ${ }^{1}$, Witold Kołłątaj ${ }^{1}$, Maria Klatka ${ }^{1}$, \\ Barbara Kołłątaj², Elżbieta Budzyńska ${ }^{1}$ \\ ${ }^{1}$ Klinika Endokrynologii i Diabetologii Dziecięcej, \\ Uniwersytecki Szpital Dziecięcy w Lublinie \\ ${ }^{2}$ Katedra i Zakład Epidemiologii i Metodologii Badań Klinicznych, \\ Uniwersytet Medyczny w Lublinie
}

Wstęp: Niewłaściwe żywienie i brak nadzoru nad prawidłową aktywnością fizyczną dziecka prowadzące do otyłości może być rozumiane jako forma szeroko pojętej niewłaściwej opieki nad dzieckiem, a w szerszym znaczeniu - także zespołu dziecka krzywdzonego. Celem pracy jest przedstawienie przykładów takiego właśnie podłoża otyłości u pacjentów kierowanych do opieki endokrynologicznej.

Materiał i metody: Materiał stanowili pacjenci Kliniki Endokrynologii i Diabetologii Dziecięcej z Pracownią Metaboliczną Uniwersytetu Medycznego w Lublinie, Poradni Endokrynologicznej Uniwersyteckiego Szpitala Dziecięcego w Lublinie oraz Poradni Endokrynologicznej Centrum Medycznego Chodźki 17 w Lublinie. Dane dotyczące pacjentów - ich warunków rodzinnych, wyżywienia i postaw żywieniowych - zbierano podczas wywiadu lekarskiego związanego z hospitalizacją lub udzielaniem pomocy poradnianej dziecku/nastolatkowi z otyłością.

Wyniki: Przedstawiono przykłady pacjentów spełniających kryteria otyłości lub znacznej nadwagi, którzy w swoich domach rodzinnych spotkali warunki niekorzystne dla ich prawidłowego rozwoju fizycznego. Dane $\mathrm{z}$ wywiadu przedstawiono $\mathrm{w}$ postaci opisu przypadków oraz tabeli podsumowującej najistotniejsze aspekty związane $\mathrm{z}$ nieprawidłową opieką nad dzieckiem.

Wnioski: 1. Otyłość jest zespołem polietiologicznym, który może mieć swoje podłoże w niewłaściwie sprawowanej opiece nad dzieckiem. 2. Niewłaściwa opieka nad dzieckiem prowadząca do uszczerbku na zdrowiu, w tym do nadwagi lub otyłości, może być traktowana jako przestępstwo wobec prawa zakazującego maltretowania dzieci. 3. W Polsce istnieje niewystarczająca świadomość praw dziecka i obowiązków opiekunów, dlatego niektóre działania o charakterze szeroko pojmowanego krzywdzenia dzieci umykają uwadze lekarzy. 4. Psychopatologiczne podłoże wielu przypadków otyłości u dzieci wskazuje na potrzebę ustalenia konsensusu postępowania $\mathrm{w}$ takich sytuacjach zarówno na poziomie lekarza POZ, jak i specjalisty.

Introduction: Improper nutrition and the lack of supervision over proper physical activity of a child leading to obesity can also be understood as a form of improper child care and therefore also as manifestation of child abuse. 
Objective: The aim of the work is to present examples of such causes of obesity in patients referred to endocrine care.

Material and methods: The material comprised patients from the Department of Pediatric Endocrinology and Diabetology with the Metabolic Laboratory of the Medical University of Lublin, the Endocrinology Outpatient Clinic of the University Children's Hospital in Lublin and the Endocrinology Outpatient Clinic of the Chodźki 17 Medical Center in Lublin. Data regarding patients - their family conditions, nutrition and nutritional attitudes - were collected during a medical interview related to hospitalization or providing assistance to a child/ adolescent with obesity.

Results: The research presents examples of patients meeting the criteria of obesity or significant overweight. Those patients encountered unfavorable conditions for their proper physical development in their family homes. The data from the medical history is presented in the form of a case description and a table summarizing the most important aspects related to the incorrect care of a child.

Conclusions: 1 . Obesity is a polyetiological syndrome that may have its own background in improperly looked after child. 2. Improper child care leading to bodily injury, including overweight or obesity, can be treated as a crime against the law prohibiting child abuse. 3. In Poland, there is insufficient awareness of children's rights and guardianship duties, hence some activities of broadly understood abuse of children escape the attention of doctors. 4. The psychopathological basis of many cases of obesity in children indicates the need to establish a consensus to deal with such situations both at the level of a primary care physician and a specialist.

\section{P08}

\section{Ocena parametrów gospodarki lipidowej, węglowodanowej i aktywności aminotransferaz u nastolatków z otyłością olbrzymią w korelacji ze stłuszczeniem wątroby}

\section{Evaluation of lipid, carbohydrate and transaminase parameters in adolescents with morbid obesity in correlation with hepatic steatosis}

Dorota Artemniak-Wojtowicz ${ }^{1}$, Maria Krajewska ${ }^{1}$, Ewelina Witkowska-Sędek ${ }^{1,2}$, Anna Majcher ${ }^{1,2}$, Beata Pyrżak ${ }^{1,2}$

${ }^{1}$ Oddział Kliniczny Endokrynologii i Pediatrii, Samodzielny Publiczny Dziecięcy Szpital Kliniczny w Warszawie

${ }^{2}$ Klinika Pediatrii i Endokrynologii, Warszawski Uniwersytet Medyczny

Wstęp: Otyłość olbrzymia dotyczy coraz większej grupy dzieci i wiąże się z występowaniem powikłań me- tabolicznych, w tym niealkoholowej stłuszczeniowej choroby wątroby (non-alcoholic fatty liver disease - NAFLD). W celu ustalenia rozpoznania NAFLD wykonuje się badania obrazowe oraz badania biochemiczne, a także wykorzystuje się nowe markery i algorytmy diagnostyczne uszkodzenia hepatocytów.

Cel: Celem pracy była analiza wskaźników insulinooporności oraz cech biochemicznych stłuszczenia wątroby u nastolatków z otyłością olbrzymią (BMI $>40 \mathrm{~kg} / \mathrm{m}^{2}$ ) przy użyciu powszechnie dostępnych metod badawczych.

Material i metody: Badanie miało charakter retrospektywny. Analizą objęto pacjentów diagnozowanych w Klinice Pediatrii i Endokrynologii. Do badania zakwalifikowano 23 pacjentów (8 dziewcząt i 15 chłopców) w wieku 13-18 lat $\mathrm{z}$ otyłością olbrzymią (BMI SDS $>3$ wg WHO). Oceniano profil lipidowy (cholesterol całkowity, HDL cholesterol, LDL cholesterol, triglicerydy), aktywność aminotransferaz (ALT, AST) oraz stężenie glukozy i insuliny na czczo i po obciążeniu glukozą. Wyliczono HOMA-IR, QUICKI, Matsuda Index. W badaniu ultrasonograficznym oceniano obecność stłuszczenia wątroby. Dane analizowano w całej badanej grupie oraz w podgrupach w zależności od obecności stłuszczenia wątroby.

Wyniki: Stłuszczenie wątroby w obrazie ultrasonograficznym opisano u 11 pacjentów (50\% badanych). W całej badanej grupie stwierdzono zwiększone stężenie triglicerydów (> $90 \mathrm{mg} / \mathrm{dl}$ ) u 94,44\% badanych, zwiększone stężenie cholesterolu całkowitego (>170 mg/dl) u 27,77\% pacjentów, LDL cholesterolu (> $110 \mathrm{mg} / \mathrm{dl})$ u 5,55\% nastolatków oraz zmniejszone stężenie HDL cholesterolu ( $<45 \mathrm{mg} / \mathrm{dl})$ u 88,88\%. Podwyższoną aktywność aminotransferaz, zarówno ALT, jak i AST, stwierdzono jedynie u 4,35\% pacjentów. W podgrupie pacjentów ze stłuszczeniem wątroby aktywność ALT $(p<0,05)$ i AST $(p<0,05)$ była istotnie statystycznie wyższa. Nie stwierdzono istotnych korelacji pomiędzy wartościami BMI SDS i zawartością procentową tłuszczu a parametrami gospodarki lipidowej i aktywnością aminotransferaz zarówno w całej badanej grupie, jak i obu podgrupach. W całej grupie wykazano dodatnią korelację pomiędzy BMI SDS a stężeniem glukozy na czczo $(r=0,44, p<0,05)$ oraz $\mathrm{HbA}_{1 \mathrm{c}}(r=0,54, p<0,05)$. Stężenie glukozy w 60 . minucie testu OGTT $(p<0,05)$ było istotnie statystycznie wyższe w grupie pacjentów ze stłuszczeniem wątroby. Stwierdzono dodatnią korelację pomiędzy procentową zawartością tłuszczu (\%FAT) a glukozą w 120. minucie testu OGTT $(r=0,82, p<0,05)$ i insuliną w 120 . minucie testu OGTT $(r=0,82, p<0,05)$ w podgrupie pacjentów bez stłuszczenia wątroby.

Wnioski: Aktywność aminotransferaz jest istotnie wyższa u pacjentów ze stłuszczeniem wątroby, natomiast parametry gospodarki lipidowej nie różnią się istotnie w obu podgrupach. BMI SDS koreluje ze stężeniem glukozy na czczo i $\mathrm{HbA}_{1 \mathrm{c}}$ w całej grupie. Stężenia glukozy 
w 60. minucie OGTT są istotnie statystycznie wyższe u pacjentów ze stłuszczeniem wątroby.

Introduction: Morbid obesity affects a growing group of children and is associated with the occurrence of metabolic complications including non-alcoholic fatty liver disease (NAFLD). To establish the diagnosis of NAFLD, imaging and biochemical tests are performed, new markers and diagnostic algorithms for hepatocyte damage are used.

Objective: The aim of the study was to analyze insulin resistance indexes and biochemical characteristics of fatty liver disease in adolescents with morbid obesity (BMI over $40 \mathrm{~kg} / \mathrm{m}^{2}$ ) using commonly available research methods.

Material and methods: The study was retrospective. The analysis included patients diagnosed at the Department of Paediatrics and Endocrinology. In the study 23 patients ( 8 girls and 15 boys) aged 13-18 years with morbid obesity (BMI SDS $>3$ according to WHO) were analyzed. Lipid profile (total cholesterol, HDL-cholesterol, LDL-cholesterol, triglycerides), transaminases (ALT, AST), fasting glucose and insulin and after oral glucose tolerance test were assessed. HOMA-IR, QUICKI, Matsuda Index were calculated. Ultrasound examination evaluated the presence of fatty liver. Data were analyzed in the entire study group and in subgroups depending on the presence of fatty liver.

Results: Fatty liver was found in 11 patients $(50 \%$ of subjects) using ultrasound image. In the entire study group elevated triglycerides $(>90 \mathrm{mg} / \mathrm{dl}$ ) were found in $94.44 \%$ of subjects, elevated total cholesterol (>170 mg/ dl) in $27.77 \%$ of patients, LDL-cholesterol $(>110 \mathrm{mg} / \mathrm{dl})$ in $5.55 \%$ of adolescents and decreased HDL-cholesterol concentration $(<45 \mathrm{mg} / \mathrm{dl})$ in $88.88 \%$. Elevated transaminases, both ALT and AST, were found in only $4.35 \%$ of patients. In the subgroup of patients with fatty liver, ALT $(p<0.05)$ and AST $(p<0.05)$ was statistically significantly higher. BMI SDS values and the percentage of body fat (\%FAT) did not correlate with the parameters of lipid metabolism and aminotransferase activity both in the entire study group and in both subgroups. The whole group showed a positive correlation between BMI SDS and fasting glucose $(r=0.44, p<0.05)$ and $\mathrm{HbA}_{1 \mathrm{c}}(r=$ $0.54, p<0.05)$. Glucose concentration at the $60^{\text {th }}$ minute of OGTT $(p<0.05)$ was statistically significantly higher in the group of patients with hepatic steatosis. A positive correlation was found between the percentage of body fat (\%FAT) and glucose at the $120^{\text {th }}$ minute of OGTT ( $r=$ $0.82, p<0.05)$ and insulin at the $120^{\text {th }}$ minute of OGTT $(r=0.82, p<0.05)$ in a group of patients without fatty liver.

Conclusions: Aminotransferase activity is significantly higher in patients with hepatic steatosis, while the parameters of lipid metabolism do not differ significantly in both subgroups. BMI SDS correlates with fasting glucose and $\mathrm{HbA}_{1 \mathrm{c}}$ in the whole group. Glucose concentrations at $60^{\text {th }}$ minute of OGTT are statistically significantly higher in patients with hepatic steatosis.

\section{P09 \\ Ocena wpływu stężeń \\ 25-hydroksywitaminy D na profil metaboliczny i stężenie białka C-reaktywnego u nastolatków z otyłością olbrzymią i nadwagą}

The influence of 25-hydroxyvitamin D level on metabolic profile and $C$-reactive protein concentration in adolescents with morbid obesity and overweight

Maria Krajewska ${ }^{1,2}$, Dorota Artemniak-Wojtowicz ${ }^{1}$, Ewelina Witkowska-Sędek ${ }^{1,2}$, Anna Majcher ${ }^{1,2}$, Beata Pyrżak ${ }^{1,2}$

${ }^{1}$ Oddział Kliniczny Endokrynologii i Pediatrii,

Samodzielny Publiczny Dziecięcy Szpital Kliniczny w Warszawie ${ }^{2}$ Klinika Pediatrii i Endokrynologii, Warszawski Uniwersytet Medyczny

Wstęp: Dane z piśmiennictwa wskazują na istnienie zależności pomiędzy zasobami witaminy $\mathrm{D}$ a zawartością tkanki tłuszczowej, profilem metabolicznym oraz nasileniem procesu zapalnego u dzieci z nadwagą i otyłością. Jednak wyniki dostępnych badań nie są w pełni zgodne i zagadnienie to wymaga dalszej analizy.

Cel: Celem pracy była ocena wpływu zasobów witaminy D na profil metaboliczny i stężenie białka C-reaktywnego (CRP) u nastolatków z otyłością olbrzymią $\left(\mathrm{BMI}>40 \mathrm{~kg} / \mathrm{m}^{2}\right)$ i nadwagą.

Materiał i metody: Badanie miało charakter retrospektywny. Analizą objęto pacjentów diagnozowanych w Klinice Pediatrii i Endokrynologii. Do badania zakwalifikowano 48 pacjentów w wieku 12-18 lat, w tym 23 pacjentów (8 dziewcząt i 15 chłopców) z otyłością olbrzymią (BMI SDS $>3 \mathrm{wg}$ WHO) oraz 25 pacjentów (10 dziewcząt i 15 chłopców) z nadwagą (BMI SDS < 2 wg WHO). Oceniano parametry antropometryczne, zawartość tkanki tłuszczowej (\%FAT), stężenia 25-hydroksywitaminy D [25(OH)D], glukozy i insuliny na czczo i po obciążeniu glukozą, wartości $\mathrm{HbA}_{1 \mathrm{c}}$, profil lipidowy (stężenia cholesterolu całkowitego, LDL-cholesterolu, HDL-cholesterolu i TG) oraz stężenie CRP. Wyliczono wskaźniki insulinooporności - HOMA-IR, QUICKI, Matsuda Index. Dane analizowano w całej badanej grupie i w podgrupach.

Wyniki: Dzieci z otyłością olbrzymią miały istotnie statystycznie niższe stężenia 25(OH)D $(p<0,05)$, QUICKI $(p<0,01)$ i HDL cholesterolu $(p<0,0001)$ oraz istotnie 
wyższe wartości insuliny na czczo $(p<0,001)$, HOMA-IR $(p<0,01)$, Matsuda Index $(p<0,01), \mathrm{TG}(p<0,01)$ i CRP $(p<0,001)$. W całej grupie stwierdzono istotnie statystycznie ujemne korelacje pomiędzy stężeniem 25(OH)D a wiekiem $(r=-0,31, p<0,05)$ i BMI SDS $(r=-0,38$, $p<0,05)$. Nie wykazano istotnych zależności pomiędzy $25(\mathrm{OH}) \mathrm{D}$ a parametrami gospodarki węglowodanowej, lipidowej i stężeniem CRP.

Wnioski: U dzieci z otyłością olbrzymią w porównaniu $\mathrm{z}$ dziećmi $\mathrm{z}$ nadwagą stwierdza się niższe zasoby witaminy D oraz większą insulinooporność, gorszy profil lipidowy i wyższe stężenia CRP. Stężenia 25(OH)D nie korelują istotnie $\mathrm{z}$ profilem metabolicznym i stężeniami CRP, zarówno w całej badanej grupie, jak i w podgrupach w zależności od nadmiaru masy ciała.

Introduction: Data from the literature indicate a relationship between vitamin $\mathrm{D}$ and adipose tissue, metabolic profile and inflammatory process in overweight and obese children. The results of the studies are not fully compatible and require further analysis.

Objective: The aim of the study was to assess the effect of vitamin D on metabolic profile and C-reactive protein (CRP) concentration in two groups: overweight adolescents and with morbid obesity (BMI $\left.>40 \mathrm{~kg} / \mathrm{m}^{2}\right)$.

Material and methods: The study was retrospective. The analysis included patients diagnosed at the Department of Paediatrics and Endocrinology. The studied group consisted of 48 patients aged 12-18 years, including 23 patients ( 8 girls and 15 boys) with morbid obesity (BMI SDS $>3$ according to WHO) and 25 overweight patients (10 girls and 15 boys) (BMI SDS $<2$ according to $\mathrm{WHO})$. The analysis included anthropometric parameters, fat tissue content (\%FAT), 25-hydroxyvitamin D concentration $[25(\mathrm{OH}) \mathrm{D}]$, fasting glucose and insulin and after oral glucose tolerance test, $\mathrm{HbA}_{1 \mathrm{c}}$, lipid profile (total cholesterol, LDL and HDL cholesterol and TG) and CRP concentration. The insulin resistance indexes were calculated - HOMA-IR, QUICKI, Matsuda Index. The data were analyzed in the entire study group and subgroups.

Results: Children with morbid obesity had statistically lower concentrations of $25(\mathrm{OH}) \mathrm{D}(p<0.05)$, QUICKI $(p<0.01)$ and HDL-cholesterol $(p<0.0001)$ and significantly higher fasting insulin values $(p<0.001)$, HOMA-IR $(p<0.01)$, Matsuda Index $(p<0.01)$, TG $(p<0.01)$ and CRP $(p<0.001)$. In the entire study group there were statistically significant negative correlations between the concentration of 25(OH)D and age $(r=-0.31, p<0.05)$ and BMI SDS $(r=-0,38, p<0.05)$. There were no significant relationships between $25(\mathrm{OH}) \mathrm{D}$ and parameters of carbohydrate profile, lipid profile and CRP.

Conclusions: Children with morbid obesity in comparison with overweight patients have lower vitamin D and higher insulin resistance, poorer lipid profile and higher CRP levels. 25(OH)D concentration do not significantly correlate with metabolic profile and CRP, both in the entire study group and in subgroups depending on excess body weight.

\section{P10 \\ Ocena żywności oferowanej w szkołach i kupowanej przez uczniów na terenie Rzeszowa}

\section{Evaluation of food offered in schools and bought by students in Rzeszów}

Agnieszka Momora ${ }^{1}$, Artur Mazur ${ }^{2}$

${ }^{1}$ Katedra Zdrowia Publicznego, Dietetyki i Chorób Cywilizacyjnych, Wyższa Szkoła Informatyki i Zarządzania w Rzeszowie

${ }^{2}$ Wydział Medyczny, Uniwersytet Rzeszowski

Wstęp: Dzieciństwo jest szczególnie istotnym etapem w rozwoju człowieka. Przebieg procesów zachodzących $\mathrm{w}$ organizmie $\mathrm{w}$ wieku szkolnym determinuje jakość życia w latach późniejszych. Według badań epidemiologicznych nieustannie rośnie liczba osób z nadwagą i otyłością, szczególnie wśród młodego pokolenia. Największy wpływ na postępowanie żywieniowe dzieci i młodzieży mają ich opiekunowie oraz środowisko towarzyszące w okresie dzieciństwa i dorastania. Kształtowanie nawyków żywieniowych zależy również od sprawowanej w danym państwie polityki żywieniowej. W Polsce prawo obejmujące asortyment dostępny w sklepikach oraz $\mathrm{w}$ automatach szkolnych reguluje ustawa $\mathrm{z}$ dnia 26 lipca $2016 \mathrm{r}$

Cel pracy: Celem badania była ocena żywności oferowanej i kupowanej przez uczniów z rzeszowskich szkół. Ponadto zadaniem pracy była analiza szacunkowego spożycia oraz częstotliwości zakupu produktów dostępnych w sprzedaży w objętych badaniem szkołach.

Materiał i metody: Badaniem objęto 52 szkoły: podstawowe (34) i gimnazjalne (17) na terenie miasta Rzeszowa. W analizie uczestniczyło 1556 uczniów. Każdy pracownik sklepiku szkolnego zapisywał, jakie produkty uczniowie zakupili w ciągu całego dnia. Dane zostały zabierane przez okres 3 dni. Dane weryfikowano za pomocą autorskiej tabeli. Uwzględniono w niej produkty zawarte $\mathrm{w}$ publikacjach $\mathrm{z}$ lat wcześniejszych oraz przekąski, które zostały wprowadzone do asortymentu po nowelizacji rozporządzenia z dnia 26 lipca 2015 r. Produkty podzielono na 29 kategorii. W badaniu uwzględniono również przekąski, które były widoczne na witrynie sklepiku szkolnego, jednak zostały celowo pominięte przez sprzedawców. Analizą objęto również automaty z żywnością. Produkty zostały podzielone na takie, które 
spełniają przepisy, bądź niekwalifikują się do norm zawartych w rozporządzeniu.

Wyniki: Przekąskami najczęściej wybieranymi przez uczniów były produkty $\mathrm{z}$ wysoką zawartością cukru, stanowiące ponad 1/3 asortymentu sklepików w szkołach podstawowych i gimnazjalnych. Gimnazjaliści kupowali o blisko $20 \%$ więcej takich przekąsek aniżeli uczniowie szkół podstawowych. Najchętniej spośród nich wybierali słodkie napoje i drożdżówki. Największą część asortymentu automatów stanowiły słodkie napoje, słodycze i słone przekąski. Zajmowały one około $50 \%$ ekspozycji. Nie wykazano istotnej statystycznie zależności $(p=0,12)$ pomiędzy sprzedażą produktów zgodnych i niezgodnych z ustawą. Wykazano, że 10\% sklepików posiadało asortyment niedostosowany do wymogów rozporządzenia.

Wnioski: Asortyment sklepików szkolnych uległ zmianie po wprowadzeniu w życie przepisów rozporządzenia Ministra Zdrowia z dnia 26 lipca 2016 r. Pomimo nowelizacji uczniowie nadal często sięgają po wysokoprzetworzone przekąski. Pozytywną zmianą po uchwaleniu ustawy jest spadek spożycia słodkich napojów gazowanych. Wprowadzone restrykcje znacząco zawęziły zakres asortymentu, zmniejszając tym samym ilość produktów, które zawierają ponad 15 g cukru czy 10 g tłuszczu w 100 g porcji. Ze względu na niezadowalające wyniki dotyczące preferencji żywieniowych dzieci wskazane wydaje się wprowadzenie programów edukacyjnych $\mathrm{z}$ zakresu zdrowego odżywiania.

Introduction: Childhood is a vital phase in human development. The processes which take place in the organism in this age span determine the person's quality of life. An increase in the percentage of overweight and obese people has been observed, particularly among the younger generations. The formation of eating habits in children is greatly influenced by the environment. Another important factor is the national nutrition policy. In Poland, the standards for food offered in school stores and vending machines are regulated by Order of 26 July 2016 of the Minister of Health Care.

Objective: The purpose of this study is the assessment of food offered in schools in Rzeszów. Moreover, the estimated consumption of products available for purchase in schools is examined.

Material and methods: The study covered 52 schools in Rzeszów - 34 primary schools and 17 lower secondary schools. An overall of 1556 students were included in the research. Every vendor was asked to keep an inventory of products purchased by students for 3 consecutive days. In each of the examined institutions, the range of products in vending machines was recorded and children's choices were observed. An additional analysis of products was executed with regard to the content of carbohydrates, proteins, fats and salt. The products were grouped into those complying and not complying with nutrition standards.

Results: Children most frequently purchased are sweet drinks and sweet buns. When the preferences of children at preliminary and lower secondary schools are compared, a statistically significant $(p<0.001)$ diversity in preferred products is shown. In most vending machines, sweets and salty snacks are the main group of offered products. No statistically significant $(p=0.12)$ relation was shown between the selling of products compliant and non-compliant with standards.

Conclusions: The range of products offered on school grounds changed under the influence of Order of 26 July 2016 of the Minister of Health Care. Snacks most often chosen by children are sweet products. the newly introduced restrictions have narrowed down the available product range, significantly decreasing the amount of products which contain more than 15 grams of sugar or 10 grams of fat in a portion of 100 grams. Due to unsatisfactory results concerning children's nutrition preferences, it appears appropriate to introduce more nutrition education programs.

\section{P11 \\ Problemy terapii otyłości u dzieci i młodzieży w leczeniu uzdrowiskowym}

Barbara Bajda, Magdalena Kostka, Agata Warwas

Śląskie Centrum Rehabilitacyjno-Uzdrowiskowe im. dr. A. Szebesty w Rabce-Zdroju

Wstęp: Otyłość i nadwaga to jeden z najpoważniejszych problemów zdrowia publicznego zarówno w krajach rozwiniętych, jak i rozwijających się. Częstość występowania chorób związanych $\mathrm{z}$ otyłością rośnie wraz ze wzrostem częstości otyłości u dzieci, dlatego też obecnie otyłość traktujemy jako chorobę przewlekłą wymagającą wielospecjalistycznej opieki medycznej. W badaniu opublikowanym w 2012 r. w ramach projektu TOY BOY wykazano, że w Polsce wśród dzieci w wieku przedszkolnym (od 4 do 7 lat) ponad $18 \%$ ma nadwagę, a niemal $12 \%$ jest otyłych. Wychodząc naprzeciw problemom leczenia otyłości u dzieci i młodzieży, w Śląskim Centrum Rehabilitacyjno-Uzdrowiskowym im. dr. Adama Szebesty w Rabce-Zdroju Spółka z o.o. podjęto wyzwanie, jakim była zmiana operatu uzdrowiskowego dla miasta Rabki polegająca na rozszerzeniu liczby kierunków leczniczych dla uzdrowiska Rabka-Zdrój o kierunek leczniczy: otyłość. Pozwoliło to na rozszerzenie kontraktu z NFZ i umożliwia przyjazd do Rabki-Zdroju dzieci z otyłością. Roczne starania o dołożenie do operatu jednego słowa „otyłość” sfinalizowaliśmy w czerwcu 2013 r. po zatwierdzeniu programu leczenia 
otyłości przez konsultanta wojewódzkiego w dziedzinie endokrynologii dr hab. n. med. Dorotę Pach i ministra Sławomira Neumanna.

Material i metody: Program przedstawia się następująco. Podstawą leczenia otyłości jest odpowiednio dobrana, zbilansowana dieta o zmniejszonej kaloryczności, modyfikacja zachowań żywieniowych oraz zwiększenie aktywności fizycznej. Struktura kompleksowego leczenia otyłości w Śląskim Centrum Rehabilitacyjno-Uzdrowiskowym w Rabce-Zdroju oparta jest na 5 składowych: lekarz - ocena stanu zdrowia, ewentualnych chorób współistniejących, pomiaru obwodów talii, bioder, procentowej zawartości tkanki tłuszczowej i mięśniowej, masy ciała, wzrostu, BMI - przed i po terapii, określenie celów, zlecenie odpowiednich zabiegów; fizjoterapeuta - praca z pacjentem indywidualna i grupowa, zabiegi z klimatoterapii, balneoterapii, hydroterapii, kinezyterapii o dawkowanym natężeniu, nauczenie systematycznego nawyku ćwiczeń dostosowanych do wieku dziecka; psycholog - spotkanie $\mathrm{z}$ psychologiem $\mathrm{w}$ formie indywidualnych konsultacji i tzw. grup wsparcia $\mathrm{z}$ innymi pacjentami - wymiana doświadczeń, przeprogramowanie psychiki na nowy styl życia, wyuczenie nowych nawyków, psychoedukacja; dietetyk - ułożenie indywidualnej diety niskokalorycznej, niskocholesterolowej, niskosodowej, edukacja w zakresie zdrowego odżywiania się. Programy edukacyjne i współpraca z dziećmi podzielona jest na dwie grupy. Grupa I to dzieci przybywające na leczeniu samodzielnie, $\mathrm{w}$ wieku od 7 do 18 lat. Cele: praca indywidualna i grupowa $\mathrm{z}$ dziećmi, lekarz - psycholog - dietetyk - fizjoterapeuta, pomoc w zmianie zachowań żywieniowych, wyuczenie zdrowych nawyków żywieniowych i aktywności fizycznej. Rozmowy $\mathrm{z}$ rodzicami $\mathrm{w}$ trakcie trwania turnusu, samodzielnie i w grupach, przy wypisie wręczenie przykładowych jadłospisów uwzględniających zapotrzebowanie kaloryczne dziecka i schorzenia współistniejące, zlecenie dalszej kontroli w poradni dietetycznej i kontynuacji rehabilitacji ruchowej (zestaw przykładowych ćwiczeń). Grupa II to dzieci przebywające na leczeniu $\mathrm{z}$ opiekunem, $\mathrm{w}$ wieku od 3 do 8 lat. Cele: edukacja rodziców samodzielnie i w grupach, przy wypisie wręczenie przykładowych jadłospisów uwzględniających zapotrzebowanie kaloryczne dziecka i schorzenia współistniejące, zlecenie dalszej kontroli w poradni dietetycznej i kontynuacji rehabilitacji ruchowej (zestaw przykładowych ćwiczeń). Wskazanie opiekunom/rodzicom konieczności corocznego korzystania z leczenia uzdrowiskowego dzieci w celu kontynuacji kuracji i wdrażania zdrowych nawyków żywieniowych. Programy edukacyjne są dostosowane do indywidualnych potrzeb pacjenta i są prowadzone przez lekarzy, psychologa i dietetyka. Poza planowanymi zabiegami rehabilitacyjnymi $\mathrm{w}$ godzinach popołudniowych są przewidziane długodystansowe spacery po parku zdrojowym i wycieczki górskie po Gorcach.
Wyniki: Programem zostały objęte dzieci w turnusach 27-dniowych przyjeżdżające ze skierowaniem na leczenie uzdrowiskowe z rozpoznaniem nadwagi i otyłości. Czas realizacji programu - 11 miesięcy: 28 czerwca 2013 r. do 2 czerwca 2014 r. (11 turnusów) - dotyczy dzieci w wieku od 6. do 18. roku życia. W okresie tym przyjęto 1449 dzieci, w tym z nadwagą i otyłością 220 dzieci, co stanowi $15,2 \%$ hospitalizowanych w naszym Centrum. U wszystkich dzieci objętych programem uzyskaliśmy spadek masy ciała. Spostrzeżenia psychologa: na podstawie zebranych doświadczeń poprzez pracę na stanowisku psychologa z dziećmi uczestniczącymi w programie odchudzającym w Śląskim Centrum Rehabilitacyjno-Uzdrowiskowym można zaobserwować charakterystyczne cechy osobowości dominujące w tej grupie dzieci i młodzieży. Znaczną grupę dzieci, zwłaszcza starszych, stanowią osoby odczuwające szereg frustracji związanych $\mathrm{z}$ własnym wyglądem, tj. wstyd, bezsilność oraz niechęć do samego siebie związaną między innymi z niemożnością kontrolowania własnej wagi i subiektywnymi trudnościami w powstrzymaniu swojego apetytu. Powoduje to obniżony nastrój, poczucie bycia nieatrakcyjnym, prowadząc do obniżonej samooceny $i$ braku wiary we własne możliwości. Ponadto towarzyszą temu napięcie i złość związane z ograniczeniem liczby posiłków, które jest rekompensowane podjadaniem produktów o wysokiej zawartości cukru w celu uspokojenia emocji i redukcji napięcia psychosomatycznego, zwiększając jeszcze bardziej poczucie winy, bezsilności i braku wpływu na sytuację. Osoby mające za sobą wielokrotne bezskuteczne próby odchudzania mogą wykształcić w sobie poczucie niskiej skuteczności w osiąganiu wybranych celów, co przekłada się na nieskuteczne radzenie sobie w życiu codziennym. Wielokrotnie dzieci muszą się konfrontować z krytyką i nieprzyjemnymi komentarzami ze strony rówieśników, co dodatkowo zwiększa poczucie krzywdy i żalu. Kolejną kwestią, która zwraca uwagę, są trudności w kontaktach interpersonalnych. Dzieci zmagające się z nadwagą często wycofują się z kontaktów społecznych lub przeciwnie - pomimo odczuwanego wstydu starają się zajmować $\mathrm{w}$ grupie znaczącą pozycję ze względu na chęć zyskania akceptacji ze strony rówieśników. Dużym utrudnieniem $\mathrm{w}$ procesie odchudzania się u dzieci są utrwalone nieprawidłowe nawyki żywieniowe. Dzieci podają, że jedzą bardzo nieregularnie, nie jedzą śniadań, często obiad jest ich pierwszym posiłkiem, gdyż rano nie są głodne, a zjadły obfitą kolację. Posiłki są ubogie w warzywa i owoce, dominują natomiast produkty wysokowęglowodanowe. Ze względu na ograniczone możliwości finansowe rodzice często sięgają po produkty tańsze i zarazem wysokoprzetworzone, które nie zawierają żadnych wartości odżywczych, bogate są natomiast $\mathrm{w}$ tzw. puste kalorie. Wynika to także z niewiedzy rodziców oraz wprowadzania w błąd poprzez szeroko rozpowszechniane kampanie 
reklamowe. Stwierdzana jest też niska świadomość ważnej roli aktywności fizycznej i zachęcania dzieci do uprawiania sportu.

Wnioski: 1 . U wszystkich dzieci objętych programem uzyskaliśmy spadek masy ciała. 2. Dziewczynki w całej grupie wiekowej znacznie mniej chudły niż chłopcy. 3. Najlepsze efekty osiągają dzieci w okresie dojrzewania, szczególnie chłopcy. 4. Nie uzyskano spadku masy ciała u dzieci, które przyjechały z matkami lub babciami dojadanie na mieście. 5. Największy spadek masy ciała jest rejestrowany w 1 . tygodniu pobytu. 6 . Drugi tydzień pobytu okupiony jest trudnością w poruszaniu się, otarciami naskórka wynikającymi ze zwiększonej ruchliwości dzieci - zabiegi rehabilitacyjne, spacery. 7. Trzeci tydzień - ucieczka w choroby, trudności i niechęć do wyjścia na spacer i zajęcia ruchowe. 8. Brak wiedzy rodziców na temat zdrowych nawyków żywieniowych. 9. W naszym społeczeństwie od wielu pokoleń istnieje przeświadczenie, że osoby nadwagą to osoby zamożne i zdrowe. 10. Największym problemem, z którym się zetknęliśmy, jest brak zainteresowania rodziców i brak wiedzy o potencjalnych zagrożeniach wynikających z otyłości.

\section{P12 \\ Występowanie nadwagi i otyłości u 8- i 9-letnich dzieci szczecińskich - badanie pilotażowe}

\section{Occurrence overweight and obesity in 8 and 9 years old children - experience from Szczecin}

Dominika Raduchaㄹ Elżbieta Petriczko ${ }^{1}$, Mieczysław Walczak ${ }^{1}$, Anita Horodnicka-Józwa ${ }^{1}$, Teresa Adamczyk ${ }^{1}$, Justyna Domagalska-Szmit ${ }^{1}$, Agnieszka Biczysko-Mokosa ${ }^{1}$, Katarzyna Marcinkiewicz ${ }^{1}$, Marta Demiaszkiewicz ${ }^{1}$, Tomasz Jackowski ${ }^{1}$, Klaudia Bartoszewicz ${ }^{1}$, Irmina Gapińska ${ }^{1}$, Joanna Ratajczak², Danuta Umiastowska²

${ }^{1}$ Klinika Pediatrii, Endokrynologii, Diabetologii, Chorób Metabolicznych i Kardiologii Wieku Rozwojowego, Pomorski Uniwersytet Medyczny w Szczecinie 2Wydziat Kultury Fizycznej i Promocji Zdrowia, Uniwersytet Szczeciński

Wstęp: Wzrastająca częstość nadmiernej masy ciała u dzieci uzasadnia potrzebę działań profilaktycznych. Gmina Szczecin realizuje program „Odważna ósemka” przeciwdziałanie nadwadze i otyłości wśród dzieci w wieku 8 lat uczęszczających do szczecińskich szkół podstawowych. W pierwszym etapie programu kompleksowej analizie zdrowotnej poddane zostaną wszystkie ośmioletnie dzieci w Szczecinie. Dzieci z BMI $\geq 90$. centyla kwalifikują się do kolejnego etapu programu, polegającego na rocznej interdyscyplinarnej opiece lekarza, dietetyka, psychologa i specjalisty aktywności fizycznej oraz organizacji warsztatów edukacyjnych dla całych rodzin. Program trwa przez trzy kolejne lata (2016-2018).

Materiał i metody: Od 6 grudnia 2016 r. do 30 maja 2018 r. zostało zbadanych 4973 dzieci (w tym 2459 dziewczynek) 8- i 9-letnich uczęszczających do szczecińskich szkół podstawowych. Badania obejmowały pomiary podstawowych wskaźników antropometrycznych, takich jak: wysokość ciała - mierzona za pomocą stadiometru $\mathrm{z}$ dokładnością do $\pm 1 \mathrm{~cm}$, masa ciała - mierzona przy użyciu wagi lekarskiej z dokładnością do $\pm 100 \mathrm{~g}$, a także obwodu talii i bioder, ciśnienia tętniczego, analizę składu ciała $\mathrm{z}$ wykorzystaniem metody bioimpedancji elektrycznej, oraz ocenę wydolności fizycznej - z użyciem Kasch Pulse Recovery Test step-test. Obliczono wskaźnik masy ciała (body mass index - BMI) oraz wskaźnik WHR. Przyjęto kryteria opracowane przez International Obesity Task Force (IOTF).

Wyniki: Nadmierną masę ciała zdiagnozowano u 1139 pacjentów, co stanowi 23\% przebadanej populacji. Podwyższone ciśnienie tętnicze zdiagnozowano u 563 pacjentów (11,3\%). Test wydolnościowy został przeprowadzony u 4837 pacjentów. Bardzo słaba wydolność fizyczna - test przerwany (HR > 180/min) - została zdiagnozowana u 219 (4,5\%), bardzo słaba u 353 (7,2\%), słaba u 1262 (26\%), dostateczna u 1327 (27,8\%), dobra u 963 (19,9\%), bardzo dobra u 607 (12,5\%), doskonała u 106 $(2,1 \%)$ pacjentów. Do drugiego etapu programu zakwalifikowało się 765 dzieci (BMI $\geq 90$. centyla), co stanowi $15,4 \%$ przebadanej populacji.

Wnioski: Niepokojący jest fakt występowania tak wysokiego odsetka nadmiernej masy ciała, sięgającego $23 \%$ wśród badanych dzieci, oraz tak wysokiego odsetka niezadowalającej wydolności fizycznej i podwyższonego ciśnienia tętniczego. Uzyskane wyniki jednoznacznie wskazują na konieczność prowadzenia wielodyscyplinarnych działań wzmacniających profilaktykę nadmiernej masy ciała oraz poprawy jakości zajęć wychowania fizycznego w szkołach podstawowych.

Introduction: Because of increasing frequency of overweight and obesity in children preventive actions are needed. Our Town Szczecin achieve the program which name is "Brave Eight" - prevention of overweight and obesity in 8 years old children attending to primary school. In the first stage all 8 years old children in Szczecin will be examined. The children with $\mathrm{BMI} \geq 90$ centyl will be qualified to the next stage. The second stage lasts one year and consists of visiting doctor, dietitian, psychologist, physiotherapist, taking part in training workshops for whole families. Our program will be realized for three years (2016-2018).

Objective: Analysis of the occurence and frequency level of the obesity, value of the blood pressure and physical endurance in a population of children between 
age of 8 and 9 from elementary schools in the area of Szczecin.

Material and methods: From 06.12.2016 to 30.05.2018 4973 of 8 and 9 years old children from primary school in our town were examined (both girls and boys). Examinations including auxological parameters: body height- measured with stadiometer with accuracy $\pm 1 \mathrm{~cm}$, body weightmeasured with medical weight with accuracy $\pm 100 \mathrm{~g}$, waist and hip circumferences, blood pressure, body composition analysis using electrical bioimpedance and physical test using Kasch Pulse Recovery Test step-test. Calculated BMI (body mass index) and WHR. Adopted criteria developed by International Obesity Task Force (IOTF).

Results: Overweight and obesity were diagnosed in 1139 patients, which is $23 \%$ examined population. Increased blood pressure was diagnosed in 563 patients (11.3\%). The efficiency test was carried out in 4837 patients. Very low level of physical endurance - test aborted (HR > 180/min) was diagnosed in $219(4.5 \%)$, very low in 353 (7.2\%), low in 1262 (26\%), sufficient in 1327 (27.8\%), good in 963 (19.9\%), very good in 607 (12.5\%), perfect in $106(2.1 \%)$. To the second stage qualified 765 children (BMI $\geq 90$ centyl), which is $15.4 \%$ examined population.

Conclusions: Alarming is the fact of occurring high percentage of obesity reaching 23\%, low level of physical endurance and increased blood pressure among examined children. Results of the test show that it's necessary to introduce multidisciplinary operations improving both prevention from excessive body weight as well the quality of physical education in elementary schools level.

\section{P13}

\section{Weryfikacja Homeostatycznej Teorii Otyłości w zakresie predyktorów wskaźnika masy ciała u dzieci: diadyczna perspektywa oceny zachowań żywieniowych dzieci}

Verification of Homeostatic Obesity Theory in the field of the body mass index predictors in children: a diadic perspective on the assessment of children's eating behaviour

Kamila Czepczor-Bernat ${ }^{1}$, Natalia Kołodziejczyk ${ }^{1}$, Anna Brytek-Matera²

${ }^{1}$ Interdyscyplinarne Studia Doktoranckie Uniwersytetu SWPS, II Wydział Psychologii, Filia we Wrocławiu

${ }^{2}$ SWPS Uniwersytet Humanistycznospołeczny, Wydział Zamiejscowy w Katowicach

Wstęp: Światowa Organizacja Zdrowia (2016) podkreśla, że rozpowszechnienie nadwagi i otyłości w grupie dzieci ciągle wzrasta, pomimo wprowadzania wielu programów prewencji i leczenia. Poszukuje się zatem no- wych sposobów rozumienia powstania i utrzymywania się nadmiernej masy ciała $\mathrm{w}$ tej grupie. Jedną z perspektyw ujęcia tego problemu jest Homeostatyczna Teoria Otyłości (Marks, 2015).

Cel: W prezentowanym badaniu skupiono się na weryfikacji predyktorów wskaźnika masy ciała u dzieci z perspektywy diadycznej (rodzic-dziecko) w zakresie oceny zachowań żywieniowych dzieci. Predyktory zostały wybrane na podstawie wspomnianej powyżej teorii Marksa (2015).

Materiał i metody: W badaniu wzięło udział 186 dzieci (wiek: $\mathrm{M}=11,08, \mathrm{SD}=2,27$ ) i 184 rodziców. $\mathrm{W}$ grupie dzieci wykorzystano następujące narzędzia: The Three-Factor Eating Questionnaire - R13 (Dzielska i wsp., 2009), Eating Disorders in Youth-Questionnaire (Hilbert i van Dyck, 2016). Rodziców proszono o uzupełnienie Child Eating Behaviour Questionnaire (Wardle i wsp., 2001).

Wyniki: Prezentowane wyniki są częścią rezultatów uzyskanych na etapie badań pilotażowych grantu Preludium 13 (2017/25/N/HS6/00004) finansowanego przez Narodowe Centrum Nauki. W badaniu zweryfikowano, czy ocena zachowań żywieniowych dzieci dokonywana przez rodziców (m.in. nadmierne spożywanie pokarmów pod wpływem emocji, niedojadanie pod wpływem emocji, reakcja na uczucie sytości) i przez dzieci (m.in. jedzenie emocjonalne, jedzenie zewnętrzne, jedzenie restrykcyjne, problemy emocjonalne związane $\mathrm{z}$ unikaniem jedzenia) jest istotnym predyktorem obecnego wskaźnika masy ciała dzieci.

Wnioski: Zarówno perspektywa oceny zachowań żywieniowych dzieci przez rodziców, jak i przez same dzieci okazała się istotna w przewidywaniu wskaźnika masy ciała dzieci.

Introduction: The World Health Organization (2016) emphasizes that the prevalence of overweight and obesity in children is constantly growing, despite the introduction of many prevention and treatment programs. Therefore, new ways of understanding of development and persistence excessive body mass in this group are sought. One of the perspectives of this issue is the Homeostatic Theory of Obesity (Marks, 2015).

Objective: The presented study focused on the verification of the body mass index predictors in children from the dyadic (parent-child) perspective in the assessment of children's eating behaviour. The predictors were chosen based on the Marks theory mentioned above (2015).

Material and methods: One hundred and eightysix children (age: $M=11.08, S D=2.27$ ) and 184 parents took part in the study. The following questionnaires were used in the group of children: Three-Factor Eating Questionnaire - R13 (Dzielska et al., 2009), Eating Disorders in Youth-Questionnaire (Hilbert and van Dyck, 2016). 
Parents were asked to complete the Child Eating Behavior Questionnaire (Wardle et al., 2001).

Results: The presented results are part of the outcomes obtained at the pilot study stage of the grant Preludium $13(2017 / 25 /$ N/HS6/00004) financed from the National Science Centre of Poland. The study verified whether the assessment of children's eating behaviors performed by parents (incl. emotional overeating, emotional undereating, satiety responsiveness) and by children (incl. emotional eating, external eating, restrictive eating, food avoidance emotional disorder) is an important predictor of the current children's body mass index.

Conclusions: Both the perspective of assessing children's eating behavior by their parents and children themselves turned out to be important in predicting children's body mass index.

\section{P14}

\section{Trudności w leczeniu pacjentów z otyłością olbrzymią - opis przypadku}

\section{Difficulties in the treatment of patients with morbid obesity - case report}

Monika Luboch-Furmańczyk ${ }^{1,2}$, Maja Okońska ${ }^{1}$, Małgorzata Myśliwiec ${ }^{1}$

${ }^{1}$ Klinika Pediatrii, Diabetologii i Endokrynologii, Uniwersyteckie Centrum Kliniczne w Gdańsku

${ }^{2}$ Klinika Pediatrii, Hematologii i Onkologii, Gdański Uniwersytet Medyczny

Wstęp: Otyłość olbrzymia i jej powikłania to coraz bardziej rozpowszechniony problem zdrowotny w populacji pacjentów pediatrycznych.

Opis przypadku: Pacjentka w wieku 12 lat 10/12 przyjęta po raz kolejny do Kliniki Pediatrii, Diabetologii, Endokrynologii UCK w Gdańsku (KPDiE) w 2016 r. Z powodu otyłości olbrzymiej oraz nadmiernego przyrostu masy ciała: $52 \mathrm{~kg} \mathrm{w}$ okresie 4 lat. Matka w wywiadzie zaprzeczała wcześniejszym hospitalizacjom. Wywiad rodzinny obciążony otyłością i cukrzycą. Wywiad ciążowy i okołoporodowy nieobciążony. Od wczesnego dzieciństwa obserwowano narastającą otyłość. W przeprowadzonej diagnostyce w KPDiE w 5. roku życia stwierdzono masę ciała $50 \mathrm{~kg}$, hiperinsulinizm i niedoczynność tarczycy; zalecono dietę, metforminę i L-tyroksynę. Po około roku metformina została odstawiona przez matkę ze względu na bóle brzucha. W kolejnych latach podczas kontrolnych hospitalizacji obserwowano przyrost masy ciała w tempie średnio $16 \mathrm{~kg} /$ rok oraz stłuszczenie wątroby $\mathrm{z}$ hipertransaminazemią, co podaje $\mathrm{w}$ wątpliwość stosowanie się do zaleceń lekarskich i dietetycznych. W 9. roku życia rozpoznano zespół bezdechu śródsennego. Wykluczono zespół Cushinga oraz zespół Pradera-Wil- liego. Obraz MRI przysadki był prawidłowy. Pacjentka nie zgłaszała się na wizyty kontrolne. Pozostawała tylko pod opieką psychologa. Podczas diagnostyki w Klinice Neurologii Rozwojowej z powodu nasilonego bólu głowy rozpoznano nadciśnienie tętnicze, włączono leczenie amlodypiną - matka odstawiła leki. W czasie ostatniej hospitalizacji pacjentki w KPDiE w 2016 r. w badaniu fizykalnym stwierdzono otyłość olbrzymią: masa ciała $168 \mathrm{~kg},>97 \mathrm{cc}, \mathrm{BMI}=56 \mathrm{~kg} / \mathrm{m}^{2},>97 \mathrm{cc}$, masa ciała przy wypisie $167 \mathrm{~kg}$, wzrost 173,8 cm, obwód talii $144 \mathrm{~cm}$, obwód bioder $148 \mathrm{~cm}$, WHtR 0,83, > $95 \mathrm{cc}$. Ponadto stwierdzono liczne rozstępy na brzuchu, bliznę po oparzeniu na klatce piersiowej, rogowacenie ciemne w okolicy dołów pachowych, steatomastię. Z odchyleń w badaniach dodatkowych obserwowano: hipertransaminazemię, dyslipidemię, w OGTT podwyższone stężenie insuliny przy normoglikemii, w USG powiększenie wątroby. Wydano zalecenia dietetyczne. Poinformowano matkę o konsekwencjach dalszego narastania otyłości u dziecka. Dziewczynkę skierowano do sanatorium w celu leczenia otyłości w trybie pilnym. Następnie skierowano do dalszej opieki diabetologicznej, hepatologicznej, dietetycznej i psychologicznej ambulatoryjnie. Matka nie zgłosiła sie z nią na zaplanowane wizyty kontrolne, nie utrzymywała kontaktu z Kliniką. Po około roku wezwana za pośrednictwem POZ podała informację, że córka przebywa w szpitalu psychiatrycznym z powodu depresji.

Wnioski: Niejednokrotnie leczenie otyłości u dzieci utrudnia brak współpracy ze strony opiekunów dziecka, którzy nie stosują się do zaleceń lekarskich i lekceważą problem, co może doprowadzić do pogorszenia stanu fizycznego i psychicznego dziecka.

Introduction: Morbid obesity and its complications are increasingly widespread health problems in the pediatric population.

Case report: The female patient aged 12 years and 10 months was once again admitted to the Department of Pediatrics, Diabetology, Endocrinology UCC in Gdańsk (KPDiE) in 2016 because of morbid obesity and excessive weight gain: $52 \mathrm{~kg}$ over 4 years. Her mother in the interview denied the earlier hospitalizations. A family history of obesity and diabetes. No complication observed during pregnancy and neonatal period. Growing obesity has been observed since childhood. In diagnostics carried out in KPDiE at the age of 5, the body weight was $50 \mathrm{~kg}$, also hyperinsulinism and hypothyroidism were found. Diet, metformin and L-thyroxine were recommended. After about a year, the metformin treatment was interrupted by her mother because of abdominal pain. In subsequent years, during control hospitalizations, weight gain was observed at an average rate of $16 \mathrm{~kg} /$ year. Also hepatic steatosis with hypertransaminasemia has been recognised, which caused doubts as to patient's com- 
pliance with medical and dietary recommendations. At the age of 9 the sleep apnea syndrome was diagnosed. Cushing's syndrome and the Prader-Willi syndrome were excluded. The pituitary MRI image was normal. The patient did not report for follow-up visits. She only consulted with a psychologist. During the diagnosis in the Department of Developmental Neurology due to severe headache, hypertension was diagnosed and amlodipine was recommended but mother discontinued the medication. During last hospitalization of the patient in KPDiE in 2016 physical examination showed morbid obesity: body weight $168 \mathrm{~kg},>97 \mathrm{pc}, \mathrm{BMI}=56 \mathrm{~kg} / \mathrm{m}^{2},>97 \mathrm{pc}$, body weight at discharge $167 \mathrm{~kg}$, growth $173,8 \mathrm{~cm}$, waist circumference of $144 \mathrm{~cm}$, hip circumference of $148 \mathrm{~cm}$, WHtR 0.83, > 95 pc. In addition, numerous stretch marks on the abdomen, a burn scar on her chest, acanthosis nigricans around armpits and adipomastia were found. Also elevated transaminases, lipid disorders, elevated insulin levels in OGTT with normo-glycaemia and hepatomegaly were observed. Dietary recommendations were given. The mother was also informed about the consequences of morbid obesity. The patient was referred urgently to a sanatorium to treat obesity. She was also referred for further diabetes, hepatology, dietary and psychological care in outpatient clinic. She did not report for control visits, did not maintain contact with the Clinic. After about a year, summoned through the GP, mother reported that her daughter is in a mental hospital because of depression.

Conclusions: Often, the treatment of obesity in children is hampered by the lack of cooperation of the child's caregivers who do not follow the medical recommendations and disregard the problem. This can lead to deterioration of the child's physical and mental state.

\section{P15 \\ Ocena składu ciała młodzieży ze szkót licealnych}

\section{Body composition assessment for high school students}

Anna Felińczak ${ }^{1}$, Janina Kulińska ${ }^{1}$, Magdalena Matuszewskaํㅡㄹ Sylwia Mizia ${ }^{1}$, Aureliusz Kosendiak ${ }^{2}$

'Zakład Organizacji i Zarządzania Katedry Zdrowia Publicznego, Uniwersytet Medyczny we Wrocławiu

${ }^{2}$ Studium Wychowania Fizycznego i Sportu, Uniwersytet Medyczny we Wroctawiu

Wstęp: Projekt „Ocena stylu życia młodzieży szkól licealnych”, realizowany w latach 2016-2018 przez Uniwersytet Medyczny we Wrocławiu, łączy narzędzia i metody badania stanu odżywienia, wiedzy i zwyczajów żywieniowych oraz zachowań zdrowotnych uczniów w wieku licealnym. Stanowi działanie diagnostyczne i profilaktyczne pozwalające zapobiec rozwojowi nadwagi i otyłości, a w konsekwencji prowadzące do zmniejszenia ryzyka wystąpienia chorób cywilizacyjnych, w tym sercowo-naczyniowych i metabolicznych. Celem pracy była analiza składu ciała młodzieży szkół licealnych.

Materiał i metody: Badaną grupę stanowiło 216 uczniów (kobiety (K)/mężczyźni (M): 129 (60\%), średni wiek 17,9 $\pm 0,8 \mathrm{roku} / 87$ (40\%), 18,2 $\pm 0,6 \mathrm{roku})$ trzech wrocławskich szkół licealnych: LO nr XIV, LO nr XV i LO nr XXIX, którzy wyrazili zgodę na udział w badaniu. Pomiar składu komponentów masy ciała został wykonany przy użyciu medycznego analizatora składu ciała Tanita SC-240 MA.

Wyniki: Analiza wykazała, że wskaźnik masy ciała (BMI) wyniósł średnio w grupie kobiet 21,7 $\pm 3,6 \mathrm{~kg} / \mathrm{m}^{2}$ (zakres 16,2-37,3 kg/m²), a w grupie mężczyzn 22,3 \pm $2,9 \mathrm{~kg} / \mathrm{m}^{2}\left(16,7-29,9 \mathrm{~kg} / \mathrm{m}^{2}\right)(p=0,036)$, przy czym w normie było $67,4 \%$ kobiet i $74,7 \%$ mężczyzn. Średnia zawartość masy tkanki tłuszczowej (FM) była na poziomie dla K: $23,5 \pm 7,7 \%(14,8 \pm 7,3 \mathrm{~kg})$ i $\mathrm{M}: 12,2 \pm 4,6 \%$ $(9,3 \pm 4,9 \mathrm{~kg})(p<0,001)$; zawartość masy tkanki beztłuszczowej (FFM) K: 76,5 $\pm 7,7 \%(45,0 \pm 3,5 \mathrm{~kg})$ i M: 87,8 $\pm 4,6 \%(63,3 \pm 7,8 \mathrm{~kg})(p<0,001), \mathrm{w}$ tym mięśni $\mathrm{K}: 72,6$ $\pm 7,3 \%(42,7 \pm 3,3 \mathrm{~kg})$ i $\mathrm{M}: 83,5 \pm 4,3 \%(60,2 \pm 7,4 \mathrm{~kg})$ $(p<0,001)$ oraz wody (TBW) K: 54,2 $\pm 5,3 \%(31,9 \pm 2,7 \mathrm{~kg})$ i M: $61,8 \pm 4,4 \%(44,4 \pm 4,7 \mathrm{~kg})(p<0,001)$. Stwierdzono: zaburzone proporcje wagowo-wzrostowe (nadwaga i otyłość) u 16,3\% kobiet i 18,4\% mężczyzn ( $p=0,686)$; zwiększoną do wieku i płci zawartość tkanki tłuszczowej w ciele u 15,5\% kobiet i 6,9\% mężczyzn ( $p=0,057)$; niedostateczne nawodnienie organizmu u $14,0 \%$ kobiet i $0 \%$ mężczyzn $(p<0,001)$.

Wnioski: Wykryte nieprawidłowości w składzie ciała wskazują na potrzebę podjęcia działań edukacyjnych wpływających na wzrost świadomości zdrowotnej. Prowadzenie badań z wykorzystaniem analizatora składu ciała jest dobrym narzędziem diagnostycznym, pozwalającym na szybkie wykrycie nieprawidłowości.

Introduction: Project Evaluation of High School Students Lifestyle carried out in 2016-2018 by the Medical University in Wroclaw combines tools and methods for studying school student's nutritional status, level of physical activity, food consumption variety and health behavior. It is a diagnostic and preventive activity that helps prevent overweight and obesity, and consequently reduce the risk of civilization diseases, including cardiovascular and metabolic diseases.

Objective: The aim of the study was to analyze the body composition of high school students.

Material and methods: The study group consisted of 216 high school students (females (F)/males (M): 129 
(60\%), average age $17.9 \pm 0.8$ years/87 $(40 \%), 18.2 \pm 0.6$ years) from three public high schools in Wroclaw: High School No. XIV, High School No. XV and High School No. XXIX. The Tanita SC-240 MA analyzer was used to measure body mass component.

Results: The analysis showed that the body mass index (BMI) was on average in the group of females $21.7 \pm 3.6$ $\mathrm{kg} / \mathrm{m}^{2}$ (range $16.2-37.3 \mathrm{~kg} / \mathrm{m}^{2}$ ), and in the group of males $22.3 \pm 2.9 \mathrm{~kg} / \mathrm{m}^{2}\left(16.7-29.9 \mathrm{~kg} / \mathrm{m}^{2}\right)(p=0.036) .67 .4 \%$ females and $74.7 \%$ males remained within normal range. The average fat mass (FMa) for females was $23.5 \pm 7.7 \%$ $(14.8 \pm 7.3 \mathrm{~kg})$ and for males: $12.2 \pm 4.6 \%(9.3 \pm 4.9 \mathrm{~kg})$ $(p<0.001)$; Fat-Free Mass (FFM) F: $76.5 \pm 7.7 \%(45.0 \pm$ $3.5 \mathrm{~kg})$ and $\mathrm{M}: 87.8 \pm 4.6 \%(63.3 \pm 7.8 \mathrm{~kg})(p<0.001)$, including muscles F: $72.6 \pm 7.3 \%(42.7 \pm 3.3 \mathrm{~kg})$ and M: 83.5 $\pm 4.3 \%(60.2 \pm 7.4 \mathrm{~kg})(p<0.001)$ and Total Body Water (TBW) F: $54.2 \pm 5.3 \%(31.9 \pm 2.7 \mathrm{~kg})$ and M: $61.8 \pm 4.4 \%$ $(44.4 \pm 4.7 \mathrm{~kg})(p<0.001)$. Results of the present study demonstrate that: (i) there's a disproportion between weight and height (overweight and obesity) for $16.3 \% \mathrm{fe}$ males and $18.4 \%$ males ( $p=0.686$ ); (ii) the Fat Mass in relations with age and gender is to high $\mathrm{F}: 15.5 \%$ and $\mathrm{M}$ : 6.9\% ( $p=0.057)$; (iii) females showed a higher insufficient hydration of the body F: $14,0 \%$ and M: $0 \%(p<0.001)$.

Conclusions: Detected abnormalities in the body composition shows the need to undertake educational activities to increase the health awareness. The body composition analyzer is a good diagnostic tool that ensure quick detection of irregularities.

\section{P16}

\section{Stan mineralizacji kośćca u otyłych dzieci i młodzieży hospitalizowanych w Klinice Propedeutyki Pediatrii i Chorób Metabolicznych Kości. Badanie pilotażowe}

\author{
Skeletal mineralization status in obese children \\ and adolescents hospitalized in the Department of \\ Paediatric Propedeutics and Bone Metabolic Diseases. \\ Pilot study \\ Katarzyna Dziedzic ${ }^{1}$, Katarzyna Haładaj², \\ Elżbieta Woźniak², Paulina Adamiecka ${ }^{1}$, Izabela Woch ${ }^{1}$, \\ Elżbieta Jakubowska-Pietkiewicz ${ }^{2}$ \\ ${ }^{1}$ Uniwersyteckie Centrum Pediatrii im. M. Konopnickiej CSK UM \\ w todzi \\ ${ }^{2}$ Kliniki Propedeutyki Pediatrii i Chorób Metabolicznych Kości, \\ Uniwersytet Medyczny w Łodzi
}

Wstęp: Otyłość jest ogólnoustrojową chorobą metaboliczną organizmu uważną za czynnik ryzyka hipowitaminozy D, a poprzez to - zaburzeń mineralizacji kośćca. Celem pracy jest zatem ocena gęstości mineralnej kości i zaopatrzenia organizmu w witaminę D u otyłych dzieci i młodzieży.

Materiał i metody: Analizie poddano wyniki badań 155 dzieci i młodzieży w wieku 5-18 lat - pacjentów Kliniki Propedeutyki Pediatrii i Chorób Metabolicznych Kości w latach 2011-2017. Spośród dzieci 70/155 (40 dziewcząt i 30 chłopców) stanowiło grupę badaną, pozostałych 85 pacjentów (45 i 40 odpowiednio) grupę odniesienia. U wszystkich dzieci wykonano pomiary antropometryczne masy i wysokości ciała zgodnie z przyjętymi metodami, a na ich podstawie wyliczono wskaźnik masy ciała (body mass index - BMI). Uzyskane wartości odniesiono do siatek centylowych opracowanych przez WHO. Otyłość rozpoznawano przy BMI > 97. percentyla - grupa badana, w grupie odniesienia BMI było $<97$. percentyla. U wszystkich pacjentów wykonano badanie densytometryczne kośćca metodą absorpcjometrii promieniowania rentgenowskiego o podwójnej energii (dual energy X-ray absorptiometry - DXA) w projekcji całego ciała (total body less head - TBlh) oraz odcinka lędźwiowego kręgosłupa (L1-4, spine). Obniżenie gęstości mineralnej kości rozpoznawano, gdy wskaźnik $Z$-score wynosił poniżej $-1,0$. Oznaczono także stężenie metabolitu wątrobowego witaminy D (25-OHD) metodą Elisa, jej niedobór rozpoznawano przy wartościach $>30 \mathrm{ng} / \mathrm{ml}$.

Wyniki: U wszystkich dzieci z otyłością gęstość mineralna kości mieściła się w granicach wartości referencyjnych dla płci i wieku. Pacjenci ci charakteryzowali się wyższymi, w porównaniu z grupą odniesienia, wartościami wskaźnika $Z$-score badania densytometrycznego zarówno w programie Tblh, jak i spine. Wykazano pozytywny związek pomiędzy gęstością mineralną kości a masą ciała i wskaźnikiem BMI. Niedobór witaminy D stwierdzono u 95,7\% otyłych dzieci i młodzieży, natomiast w grupie odniesienia odsetek ten wynosił $83,5 \%$.

Wnioski: Budowa ciała jest silnym predyktorem gęstości mineralnej kości w badanej grupie pacjentów z otyłością. U większości ocenianych dzieci wykazano niedobór witaminy $\mathrm{D}$, co stanowi wskazanie do stosowania profilaktyki i leczenia niedoborów tej witaminy w wieku rozwojowym, szczególnie u otyłych dzieci i młodzieży.

Introduction: Obesity is a systemic metabolic disease which is considered as a risk factor of hypovitaminosis D and bone mineralization disorder. The aim of the study is to evaluate mineral bone density and vitamin D supply in obese children and adolescents.

Material and methods: The results of examination 155 patients aged 5-18 years old in the Department of Paediatric Propedeutics and Bone Metabolic Diseases hospitalized in 2011-2017 was analyzed. The study group was 70/155 children ( 40 girls and 30 boys). The other 85 patients (45 and 40 respectively) was the control group. All children were performed anthropometric measurements of body 
mass and height according to the general accepted methods. Based on this results the body mass index (BMI) was calculated. The obtained data was referred to the centile grids devised by WHO. Obesity was diagnosed with BMI $>97$ percentile - study group. In the control group the BMI was below 97 percentile. All patients were performed bone densitometry using dual energy X-ray absorptiometry in the whole body projection (Total Body less head - TBlh) and lumbar spine (L1-L4). Decreased bone mineral density was diagnosed when the $Z$-Score index was below -1.0 . The concentration of the vitamin D metabolite (25-OH D) was tested by the Elisa method. Deficiency of the vitamin D metabolite was recognized below $30 \mathrm{ng} / \mathrm{ml}$.

Results: Patients of study group have bone mineral density within the limits of reference values for sex and age. In comparison with control group the $Z$-Score index of densitometry in both TBlh and spine was higher in study group. A positive relationship was found between bone mineral density, body weight and BMI. The deficiency of vitamin $\mathrm{D}$ was detected in $95.7 \%$ of obese children and adolescents, whereas in the reference group this percentage was $83.5 \%$.

Conclusions: Body structure is a strong predictor of bone mineral density in the study group. Most of the diagnosed children have vitamin $\mathrm{D}$ deficiency which is an indication for the use of prophylaxis and treatment of vitamin $\mathrm{D}$ deficiency in pediatric patients especially in obese children and adolescents.

\section{P17}

\section{Porównanie wpływu dwóch metod modyfikacji stylu życia na wybrane parametry auksologiczne oraz biochemiczne $u$ otyłych dzieci przed okresem dojrzewania}

\section{Comparison of the impact of two methods of lifestyle modification on selected auxological and biochemical parameters in obese children before puberty}

Małgorzata Wójcik ${ }^{1 \#}$, Agnieszka Kozioł-Kozakowska#, Aleksandra Furtak ${ }^{1}$, Jerzy B. Starzyk ${ }^{1}$

${ }^{1}$ Klinika Endokrynologii Dzieci i Młodzieży, Katedra Pediatrii, Instytut Pediatrii, Collegium Medicum Uniwersytetu Jagiellońskiego w Krakowie, Uniwersytecki Szpital Dziecięcy w Krakowie

${ }^{2}$ Pracownia Dietetyki Pediatrycznej, Klinika Pediatrii, Gastroenterologii i Żywienia, Collegium Medicum Uniwersytetu Jagiellońskiego w Krakowie

\#Równorzędny pierwszy autor

Wstęp: Najlepszą metodą leczenia otyłości u dzieci jest modyfikacja stylu życia poprzez zmianę sposobu żywienia i aktywności fizycznej. W dostępnej literaturze brakuje szczegółowych danych porównujących skuteczność różnych metod interwencji behawioralnych.
Materiał i metody: Do badania zakwalifikowano 20 dzieci (6 chłopców, 14 dziewczą) w wieku średnio 8,9 (SD 1,36) roku, bez cech dojrzewania płciowego. Dzieci zostały losowo przydzielone do 2 grup: (I) leczenia intensywnego $(n=11)$ i (S) leczenia standardowego $(n=9)$. $\mathrm{W}$ grupie I zastosowano interwencję polegającą na stopniowym wprowadzaniu ograniczeń żywieniowych i zwiększaniu codziennej aktywności fizycznej, ustalaniu wspólnie z rodziną zasad, które są akceptowalne i realne do stosowania. Analiza wyników leczenia i bieżące modyfikacje dietetyczne były prowadzone co 2-3 tygodnie podczas wizyt kontrolnych lekarskich i dietetycznych. Uczestnicy prowadzili dzienniczki samokontroli. W grupie $S$ przeprowadzono jednorazowe szkolenie w zakresie diety i aktywności fizycznej. Uczestnicy otrzymali rację pokarmową wraz z przykładowym 7-dniowym jadłospisem i ogólne zalecenie zwiększenia aktywności fizycznej do 45 minut dziennie. Nie stosowano żadnych metod bieżącej kontroli wyników leczenia. Na początku i po 3 miesiącach oceniono wybrane parametry auksologiczne i biochemiczne.

Wyniki: Na początku badania pomiędzy grupami I i S nie stwierdzono znamiennych różnic w zakresie BMI SDS $(3,16$ vs 4,52; $p=0,11)$, procentowej tłuszczowej masy ciała (FM) $(34,8$ vs 38,58\%; $p=0,07)$, stężenia glukozy na czczo (FG) $(4,45$ ss $4,6 \mathrm{mmol} / \mathrm{l} ; p=1,0)$, cholesterolu całkowitego (TC) (4,53 vs 4,42 mmol/l; $p=0,7)$, LDL cholesterolu (LDL) (2,78 vs 2,76 mmol/l; $p=0,9)$, HDL cholesterolu (HDL) (1,13 vs $1,14 \mathrm{mmol} / \mathrm{l} ; p=0,9)$, trójglicerydów (TG) (1,42 vs 1,46 mmol/l; $p=0,2)$, kwasu moczowego (U) $(286,1$ vs $322,5 \mu \mathrm{mol} / \mathrm{l} ; p=0,13)$. Po 3 miesiącach w obu grupach stwierdzono zmniejszenie BMI SDS oraz FM. Nie stwierdzono znamiennej różnicy w zakresie BMI SDS pomiędzy grupami I i S $(2,61$ vs 3,89; $p=0,02)$, natomiast FM była znamiennie mniejsza w grupie I $(31,23 v s 36,2 ; p=0,046)$. W obu grupach stwierdzono zmniejszenie stężenia FG $(4,44$ vs $4,58 \mathrm{mmol} / \mathrm{l}$; $p=0,1)$, TC (4,29 vs 4,33 mmol/l; $p=0,88)$, LDL (2,59 vs $2,51 \mathrm{mmol} / \mathrm{l} ; p=0,94), \mathrm{TG}(1,11$ vs $1,4 \mathrm{mmol} / \mathrm{l} ; p=0,06)$ i U $(266,3$ vs 319,9 $\mu \mathrm{mol} / \mathrm{l} ; p=0,26)$ oraz zwiększenie stężenia HDL $(1,22$ vs $1,15 \mathrm{mmol} / \mathrm{l} ; p=0,65)$. Dla żadnego $\mathrm{z}$ analizowanych parametrów różnica pomiędzy grupami I i S w zakresie wartości zmiany nie była znamienna.

Wnioski: Zmiana diety i zwiększenie aktywności fizycznej dzieci jest skuteczną metodą leczenia otyłości. Intensywna spersonalizowana interwencja dietetyczna oparta na regularnych kontrolach i bieżącej modyfikacji zaleceń może spowodować w krótkim czasie znamienną redukcję tłuszczowej masy ciała. Nie wykazano przewagi interwencji intensywnej w porównaniu $\mathrm{z}$ metodami standardowymi w zakresie poprawy parametrów biochemicznych.

Introduction: The best way of childhood obesity treatment is lifestyle modification via diet and physical activity changes. The data comparing the effecti- 
veness of various methods of behavioral interventions is lacking.

Material and method: 20 children ( 6 boys, 14 girls), mean age 8.9 (SD 1.36) years, before puberty were included to the study. Children were randomly assigned to 2 groups: (I) intensive treatment $(n=11)$, and (S) standard treatment $(n=9)$. In group I, the intervention was based on the gradual introduction of nutritional restrictions and increasing daily physical activity, in close cooperation with the family. Analysis of treatment results and current dietary modifications were carried out every 2-3 weeks during medical and dietary consultations. Participants kept self-monitoring diaries. In Group S diet consultation and advise to increase physical activity were given once. Participants received a food ration along with an example of a 7-day menu and a general recommendation to increase physical activity to 45 minutes a day. No methods of ongoing control of treatment outcomes were used. At the beginning and after three months, selected auxological and biochemical parameters were evaluated.

Results: At the beginning of the study between groups I and $\mathrm{S}$ there were no significant differences in BMISDS (3.16 vs. $4.52, p=0.11)$, \% body fat (FM) (34.8 vs. $38.58 \%$; $p=0.07)$, fasting blood glucose (FG) $(4.45$ vs. $4.6 \mathrm{mmol} / \mathrm{L}, p=1.0$ ), total cholesterol (TC) (4.53 vs. $4.42 \mathrm{mmol} / \mathrm{L} ; p=0.7)$, LDL cholesterol (LDL) (2.78 vs. $2.76 \mathrm{mmol} / \mathrm{L}, p=0.9$ ), HDL cholesterol (HDL) (1.13 vs. $1.14 \mathrm{mmol} / \mathrm{L} ; p=0.9)$, triglycerides (TG) (1.42 vs. 1.46 $\mathrm{mmol} / \mathrm{L}, p=0.2)$, uric acid (U) (286.1 vs. $322.5 \mu \mathrm{mol} / \mathrm{L}$; $p=0.13$ ). After 3 months, both groups showed a decrease in BMI SDS and FM. There was no significant difference in BMI SDS between groups I and S (2.61 vs. 3.89, $p=$ $0.02)$, while FM was significantly lower in group I (31.23 vs. $36.2, p=0.046)$. Both groups showed a decrease in FG ( 4.44 vs. $4.58 \mathrm{mmol} / \mathrm{L}, p=0.1$ ), TC ( 4.29 vs. $4.33 \mathrm{mmol} / \mathrm{L}$, $p=0.88), \mathrm{LDL}(2.59$ vs. $2.51 \mathrm{mmol} / \mathrm{L}, p=0.94), \mathrm{TG}(1.11$ vs. $1.4 \mathrm{mmol} / \mathrm{L}, p=0.06), \mathrm{U}(266.3$ vs. $319.9 \mu \mathrm{mol} / \mathrm{L} ; p=$ $0.26)$. Increase in HDL (1.22 vs. $1.15 \mathrm{mmol} / \mathrm{L}, p=0.65)$. For none of the analyzed parameters, the difference between groups I and S in the change value range was not significant.

Conclusions: Changing the diet and increasing physical activity is an effective method of treating childhood obesity. Intensive, personalized dietary intervention based on regular controls and on-going modification may result in a significant reduction in fat body mass in a short time. The advantage of intensive intervention compared to standard methods of biochemical parameters improvement has not been demonstrated.
P18

\section{Poziom 25-hydroksywitaminy D u otyłych dzieci i jego związek ze składowymi zespołu metabolicznego}

\section{5-hydroxy vitamin $D$ level in obese children and its relation to the metabolic syndrome components}

Anna Springwald ${ }^{1}$, Paweł Matusik ${ }^{1}$,

Magdalena Olszanecka-Glinianowicz², Jerzy Chudek ${ }^{3}$, Ewa Małecka-Tendera ${ }^{1}$

${ }^{1}$ Katedra i Klinika Pediatrii i Endokrynologii Dziecięcej,

Śląski Uniwersytet Medyczny w Katowicach

${ }^{2}$ Zakład Promocji Zdrowia i Leczenia Otyłości, Śląski Uniwersytet

Medyczny w Katowicach

${ }^{3}$ Katedra i Klinika Chorób Wewnętrznych i Chemioterapii

Onkologicznej, Śląski Uniwersytet Medyczny w Katowicach

Wstęp: Niedobór witaminy D i otyłość są jednymi z najpowszechniej występujących problemów zdrowotnych. Występowanie obu zaburzeń w coraz większym stopniu dotyka także dzieci i nastolatków. Ostatnie badania sugerują zależność między poziomem 25-hydroksylowanej witaminy D a metabolicznymi czynnikami ryzyka. Jakkolwiek związek między niedoborem witaminy D a zespołem metabolicznym wydaje się prawdopodobny, aktualna wiedza na ten temat jest wciąż niewielka.

Materiał i metody: Zbadano zależność między poziomem 25(OH)D i tkanki tłuszczowej, metabolizmem glukozy, profilem lipidowym i poziomem adiponektyny u 79 otyłych dzieci, średnia wieku wynosiła 14,18 $\pm 2,66$ roku. U wszystkich pacjentów została przeprowadzona szczegółowa analiza antropometryczna oraz badanie składu masy ciała za pomocą analizatorów składu masy ciała wykorzystujących zjawisko bioimpedancji.

Wyniki: Spośród otyłych dzieci $61(76,25 \%)$ miało niedobór witaminy $\mathrm{D}_{3}$. W grupie chłopców stężenie $25(\mathrm{OH}) \mathrm{D}$ było znamiennie niższe $(13,32$ vs $18,32, p<$ $0,05)$. W całej populacji poziom $25(\mathrm{OH}) \mathrm{D}$ odwrotnie korelował ze wskaźnikiem talia/wysokość ciała (WHtR), stężeniem glukozy po 2 godzinach testu doustnego obciążenia glukozą (OGTT) oraz z wiekiem dzieci. Grupa dzieci z niedoborem witaminy D miała znacząco wyższy WHtR $(0,64$ vs 0,60, $p<0,05)$, wiek $(14,5$ vs 13,04, $p<0,05)$ i stężenie trójgliderydów (171,31 vs 121,76, $p<0,05)$, ale niższy poziom HDL (45,0 vs 50,13, $p<0,05)$, adiponektyny $(7,21$ vs $8,84, p<0,05)$ oraz fT4 $(1,15 v s$ $1,29, p<0,05)$.

Wnioski: Niedobór witaminy D jest zjawiskiem bardzo częstym u otyłych dzieci, a w wysokiej mierze jest także powiązany ze składowymi zespołu metabolicznego. W przeprowadzonym badaniu obserwowano nowe relacje pomiędzy $25(\mathrm{OH}) \mathrm{D}$, pewnymi czynnikami ryzyka metabolicznego oraz adiponektyną. Wciąż jednak potrzebnych jest więcej badań na większej grupie kontrolnej. 
Introduction: Vitamin D deficiency and obesity poses one of the most widespread medical problems. The prevalence of these disorders increasingly affect the group of children and adolescent. Recent studies suggest a relationship between 25-hydroxyvitamin D (25(OH)D) and metabolic risk factors. However this relation remains unclear.

Objective: The purpose of this study was to look for these relations in obese children.

Material and methods: We investigated the relation between serum $25(\mathrm{OH}) \mathrm{D}$ and adiposity, glucose metabolism, lipid profile, and adiponectin in 79 obese children in the mean age of $14.18 \pm 2.66$ years. In all patients was performed detailed anthropometric and body composition analysis based on bioelectrical impedance using a segmental body composition analyzer.

Results: In $61(76.25 \%)$ of studied obese children were vitamin $\mathrm{D}$ deficient. The group of boys had significantly lower level of 25(OH)D (13.32 vs. 18.32, $p<$ $0.05)$. In the overall population, $25(\mathrm{OH}) \mathrm{D}$ is significantly inversely correlated with waist to height ratio (WHtR), glucose level in the $2 \mathrm{~h}$ after oral glucose administration in the OGTT and age. The group of children vitamin D deficient had significantly higher WHtR (0.64 vs. 0.60 , $p<0.05)$, age $(14.5$ vs. $13.04, p<0.05)$ and level of triglycerides (171.31 vs. $121.76, p<0.05)$, but lower level of HDL (45.0 vs. $50.13, p<0.05)$, adiponectin (7.21 vs. 8.84, $p<0.05)$ and fT4 (1.15 vs. $1.29, p<0.05)$.

Conclusions: In obese children vitamin $\mathrm{D}$ is very common feature and is significantly related to the metabolic syndrome components. We observe new relationships between $25(\mathrm{OH}) \mathrm{D}$ and several metabolic risk factors and adiponectin. Further study with larger control group is needed.

\section{P19}

\section{Użyteczność rozpoznawania zespołu metabolicznego $u$ otyłych dzieci w praktyce klinicznej}

\section{Usefulness of metabolic syndrome in obese children in clinical practice}

Anna Springwald, Paweł Matusik, Piotr Gibała, Patrycja Różana-Kowalska, Ewa Małecka-Tendera

Katedra i Klinika Pediatrii i Endokrynologii Dziecięcej, Śląski Uniwersytet Medyczny w Katowicach

Wstęp: Przydatność kliniczna rozpoznawania zespołu metabolicznego (ZM) u otyłych dzieci w świetle ostatnich badań jest kontrowersyjna. Pojawia się pytanie, czy zdiagnozowanie zespołu metabolicznego odzwierciedla ryzyko występowania powikłań otyłości u dzieci.
Materiał i metody: Analizie retrospektywnej poddano 588 otyłych dzieci leczonych w Poradni Metabolicznej, z których do badania zakwalifikowano 289 dzieci (145 chłopców) w wieku średnio 11 lat. Zespół metaboliczny diagnozowano na podstawie kryteriów IDF 2009. Do określenia insulinooporności u dzieci użyto wskaźnika HOMA-IR.

Wyniki: Zespół metaboliczny zdiagnozowano u 69 dzieci (24\%), w tym u 42 dziewczynek $(61 \%, p<0,05)$. Średni wiek dzieci był wyższy $(12,4$ vs $10,9, p<0,05) \mathrm{u}$ pacjentów z zespołem metabolicznym. Początkowy BMI Z-score był zbliżony zarówno w grupie dzieci z ZM, jak i bez ZM $(2,93$ vs 2,92). Dalsza obserwacja wykazała mniej efektywną redukcję BMI $z$-score u pacjentów z ZM (2,59 vs $2,5, p=0,0006)$. Insulinooporność była obserwowana znacząco częściej u dzieci z ZM (77\% vs 35\%, p<0,0001). Aminotransferazy były znamiennie wyższe u chłopców $\mathrm{z} \mathrm{ZM}(\mathrm{AST}=35$ vs $28 \mathrm{U} / \mathrm{l}, \mathrm{ALT}=38$ vs $23 \mathrm{U} / \mathrm{l}, p<0,0001)$.

Wnioski: Diagnozowanie zespołu metabolicznego u otyłych dzieci wydaje się mieć istotne znaczenie predykcyjne w praktyce klinicznej. Zespół ten występuje częściej u dziewczynek i u dzieci starszych. Insulinooporność jest ważnym czynnikiem skojarzonym z zespołem metabolicznym u otyłych dzieci. Terapia otyłości jest mniej efektywna u pacjentów z ZM. Chłopcy dotknięci tym zespołem są bardziej narażeni na wystąpienie niealkoholowej stłuszczeniowej choroby wątroby (NAFLD) w przyszłości.

Introduction: In the light of recent studies, the usefulness of the metabolic syndrome diagnosis in obese paediatric patients seems controversial. It leads to the pressing questions, if the metabolic syndrome diagnosis is reflecting risk of the cardiovascular complications in obese children.

Objective: The aim of our study was to evaluate the incidence of metabolic syndrome in obese children, asses the role of insulin resistance in the metabolic complications and investigate if the diagnosis of MS has a clinical value in that group of patients.

Material and methods: From records of 588 obese children treated in metabolic outpatient clinic, 289 children ( 145 boys) in the mean age of 11 years, was qualified to our study. Diagnosis of metabolic syndrome was based on IDF 2009 criteria and HOMA-IR was used to asses insulin resistance.

Results: Metabolic syndrome was diagnosed in 69 children (24\%) including 42 girls $(61 \%, p<0.05)$. Mean age was higher $(12.4$ vs. $10.9, p<0.05)$ in patients with metabolic syndrome. Initial BMI Z-score was close both in the group with metabolic syndrome and without it (2.93 vs. 2.92). Further follow-up showed less effective BMI $z$-score reduction in patients with metabolic syndrome (2.59 vs. $2.5, p=0.0006)$. Insulin resistance was 
observed significantly more often in children with metabolic syndrome ( $77 \%$ vs. $35 \%, p<0.0001)$. Aminotransferases were significantly elevated in boys with metabolic syndrome $(\mathrm{AST}=35$ vs. $28 \mathrm{U} / \mathrm{l}, \mathrm{ALT}=38$ vs. $23 \mathrm{U} / \mathrm{l}, p<$ 0.0001).

Conclusions: The diagnosis of metabolic syndrome in obese children seems to have a predictive value for the clinical practice. Affected children are older and their criteria are present more often in girls. Insulin resistance seems to be an important factor associated with metabolic syndrome in obese children. Dietary therapy is less effective in children with metabolic syndrome. Affected boys are at higher risk of nonalcoholic fatty liver disease (NASH) in the future.

\section{P20}

\section{Ocena przydatności wskaźnika TG/HDL-C w przewidywaniu występowania zespołu metabolicznego u dzieci i młodzieży z otyłością}

\section{Evaluation of the usefulness of Triglycerides to High-Density Lipoprotein Cholesterol ratio (TG/HDL-C) in prediction of metabolic syndrome in obese children and adolescents}

Małgorzata Rumińska, Monika Krawczyk, Ewelina Witkowska-Sędek, Anna Majcher, Beata Pyrżak

Klinika Pediatrii i Endokrynologii, Warszawski Uniwersytet Medyczny

Wstęp: W praktyce klinicznej do oceny insulinooporności (IR) wykorzystuje się pośrednie metody, wyliczone na podstawie wartości stężeń glukozy i insuliny na czczo lub w trakcie testu OGTT. Ostatnie badania wskazują, że stosunek stężeń triglicerydów do cholesterolu HDL (TG/ HDL-C) jest również użytecznym markerem IR. Celem pracy było porównanie przydatności wskaźnika TG/ HDL-C i innych pośrednich wskaźników IR w przewidywaniu występowania zespołu metabolicznego u dzieci i młodzieży z otyłością prostą.

Materiał i metody: Badaniem objęto 122 dzieci z otyłością prostą (średni wiek 11,6 23 lata) oraz 58 ich zdrowych rówieśników. Otyłość definiowano wg kryteriów International Obesity Task Force, zespół metaboliczny wg kryteriów International Diabetes Federation (2007). U badanych pacjentów wykonano pomiary antropometryczne, OGTT, oceniono profil lipidowy. Na podstawie otrzymanych wyników wyliczono wskaźniki TG/HDL-C oraz HOMA, FGIR, QUICKI, OGIS i Matsuda.

Wyniki: Mediana wskaźnika TG/HDL-C u dzieci otyłych wynosi 2,9 , u dzieci z zespołem metabolicznym 5,3 , dla porównania u dzieci z grupy kontrolnej 1,3. Dzie- ci otyłe ze wskaźnikiem TG/HDL-C $\geq 3(47,5 \%)$ miały wyższe wartości HOMA-IR oraz niższe wartości FGIR, QUICKI, OGIS i indeksu Matsuda w porównaniu z ich rówieśnikami z TG/HDL-C < 3. Wskaźnik TG/HDL-C dodatnio korelował z masą ciała, obwodem talii, wskaźnikiem talia/biodro (WHtR), profilem lipidowym, HOMA-IR, stężeniami insuliny na czczo oraz w trakcie testu OGTT, ujemnie z FGIR, QUICKI, OGIS i indeksem MATSUDA. Pole powierzchni pod krzywą (AUC) wyliczone dla wszystkich analizowanych markerów IR było największe dla TG/HDL-C (0,8936, 95\% Cl: 0,809-0,977, $p=0,000)$.

Wnioski: Wskaźnik TG/HDL-C może być alternatywnym narzędziem w ocenie insulinooporności u dzieci otyłych. Spośród analizowanych wskaźników IR, TG/ HDL-C wydaje się najlepszy w prognozowaniu występowania zespołu metabolicznego.

Introduction: In clinical practice, indirect methods are used to assess insulin resistance (IR). They are calculated based on glucose and insulin concentration fasting or during the oral glucose tolerance test (OGTT). Recent studies indicated, that the triglyceride to HDL cholesterol ratio (TG/HDL-C) is also a useful surrogate marker for evaluation of IR.

Objective: The purpose of this study was to compare the TG/HDL-C ratio to others indirect IR measurements calculated based on glucose and insulin concentrations, to establish its usefulness in prediction of MS in obese children and adolescents.

Material and methods: The study involved 122 obese children with the mean age of $11.6 \pm 3$ years and their 58 healthy lean peers. Obesity was defined using IOTF criteria, metabolic syndrome were applied using 2007 IDF criteria. In studied patients anthropometric measures were taken. The plasma lipid profile and oral glucose tolerance test (OGTT) were determined. Based on the obtained results, the TG/HDL-C ratio and surrogate insulin resistance indices (HOMA, FGIR, QUICKI, OGIS, Matsuda) were calculated.

Results: The median value of the TG/HDL-C ratio in obese children and adolescents was 2.9, in children with metabolic syndrome 5.3, in comparison in their healthy peers 1.3. Obese children with TG/HDL-C ratio $\geq 3$ (47.5\%) had higher values of HOMA-IR, and lower of FGIR, QUICKI, OGIS, MATSUDA compared to their obese peers with the TG/HDL-C $<3$. The TG/HDL-C ratio positively correlated with weight, waist circumference, waist to hip ratio, HOMA-IR, lipid profile, fasting insulin and insulin measurements during OGTT and negatively with FGIR, QUICKI, OGIS, MATSUDA. The area under the curve (AUC) calculated for each insulin resistance index in prediction of metabolic syndrome was the largest for the TG/HDL-C ratio $(0.8936,95 \% \mathrm{Cl}: 0.809-0.977, p=0.000)$. 
Conclusions: The TG/HDL-C ratio may be an alternative tool for the evaluation of insulin resistance in obese children. Among analysed surrogate IR markers, the TG/HDL-C ratio seems to be the best in prediction of metabolic syndrome.

\section{P21}

\section{Zespół ROHHAD (Rapid onset Obesity, Hypoventylation, Hypothalamic, Autonomic Dysfunction) jako jedna z rzadkich przyczyn otyłości u dzieci - prezentacja przypadku}

\section{ROHHAD Syndrome (Rapid onset Obesity, Hypoventylation, Hypothalamic, Autonomic Dysfunction) as a rare cause of obesity in children - case report}

Karolina Kot ${ }^{1}$, Marek Migdał², Elżbieta Moszczyńska ${ }^{1}$, Agnieszka Lecka-Ambroziak ${ }^{1}$, Mieczysław Szalecki, ${ }^{1,3}$

${ }^{1}$ Klinika Endokrynologii i Diabetologii, Instytut „Pomnik - Centrum Zdrowia Dziecka" w Warszawie

${ }^{2}$ Klinika Anestezjologii i Intensywnej Terapii, Instytut „Pomnik Centrum Zdrowia Dziecka" w Warszawie

${ }^{3}$ Wydział Lekarski i Nauk o Zdrowiu, Uniwersytet Jana Kochanowskiego w Kielcach

Wstęp: Zespół ROHHAD jest rzadkim zespołem charakteryzującym się szybko narastającą otyłością w pierwszych latach życia, zaburzeniami oddychania oraz funkcji podwzgórza i układu autonomicznego.

Material i metody: Prezentujemy przypadek 15-letniego chłopca z otyłością, zwolnieniem szybkości wzrastania, brakiem postępu pokwitania, zaburzeniami gospodarki węglowodanowej, hipowentylacją, hipodypsją, nadmierną potliwością i epizodami gorączek.

Wyniki: W trakcie prowadzonej diagnostyki w wieku 7 lat stwierdzono somatotropinową niedoczynność przysadki, umiarkowaną hiperprolaktynemię do $76 \mathrm{ng} / \mathrm{ml}$ (N: 1,8-15,9), hipernatremię 148-161 mmol/l, podwyższoną aktywność reninową osocza. Badanie MRI głowy było prawidłowe. Pacjent rozpoczął leczenie preparatem hormonu wzrostu $\mathrm{z}$ dobrym efektem. $\mathrm{Z}$ uwagi na stwierdzany w trakcie badania polisomnograficznego bezdech senny, o typie mieszanym centralno-obturacyjnym, pacjent został włączony do programu wspomagania oddechu w czasie snu. Po wprowadzeniu wsparcia oddechowego - wentylacja z użyciem dodatniego ciśnienia przez maskę - u chłopca zaobserwowano zmniejszenie nasilenia potliwości i gorączek. W badaniu genu PHOX2B (w kierunku zespołu wrodzonej ośrodkowej hipowentylacji) nie stwierdzono mutacji. W wieku 14 lat u pacjenta zauważono brak postępu pokwitania ze zwolnieniem szybkości wzrastania i do leczenia dołączono testosteron domięś- niowo. Na podstawie testu doustnego obciążenia glukozą, wykonanego $\mathrm{z}$ uwagi na utrzymywanie się/narastanie otyłości, rozpoznano cukrzycę typu 2, rozpoczęto leczenie metforminą. Ze względu na opisywane w obrazie zespołu guzy wywodzace się $\mathrm{z}$ układu współczulnego pacjent ma okresowo wykonywane badania obrazowe jamy brzusznej i klatki piersiowej (CT i USG) oraz badanie wydalania katecholamin i ich metabolitów w dobowej zbiórce moczu. Całość obrazu klinicznego, wyniki badań laboratoryjnych i obrazowych spełniają kryteria rozpoznania zespołu ROHHAD.

Wnioski: Zespół ROHHAD powinien być brany pod uwagę $\mathrm{w}$ diagnostyce różnicowej otyłości rozpoczynającej się we wczesnym dzieciństwie. Pacjenci z rozpoznanym zespołem ROHHAD z uwagi na możliwość wystąpienia objawów i powikłań ze strony różnych narządów i układów powinni jak najwcześniej znajdować się pod systematyczną i wielospecjalistyczną opieką.

Inroduction: ROHHAD syndrome (Rapid-onset Obesity, Hypoventilation, Hypothalamic, Autonomic Dysfunction) is characterised by early rapid-onset obesity in children, hypoventilation, hypothalamic and autonomic dysfunction.

Objective: Characterisation of the first described case of patient with ROHHAD syndrome in Polish population.

Material and methods: We present a 15-year-old boy with significant weight gain since early childhood, decreased height velocity, delayed progress of puberty, hyperglycemia, hypoventilation, hypodipsia, excessive perspiration, fever episodes.

Results: Laboratory tests at 7 years of life revealed growth hormone deficiency ( $\max .0 .3 \mathrm{ng} / \mathrm{mL})$, moderate hyperprolactinemia of $73 \mathrm{ng} / \mathrm{mL}(\mathrm{N}: 1.8-15.9)$, hypernatremia 148-161 mmol/L, slightly elevated plasma renin activity. Head MRI showed no abnormalities. Patient started growth hormone therapy. Mild mixed-type sleep apnea syndrome was recognized (AHI 5.5-6.3), with obstructive component in polysomnography, patient has been scheduled for home ventilation program with non-invasive mask ventilation using positive pressure. Decrease in excessive perspiration and fever episodes followed ventilation support treatment. Evaluation of PHOX2B gene (resulting in the congenital central hypoventilation) did not confirmed mutation. At the age of 14 years delayed progress of puberty and decreased growth velocity was observed, patient started therapy with low doses of testosterone i.m. He also developed type 2 diabetes and has being treated with metformin. Due to increased risk of neural crest origin tumors imaging follow-up (USG and CT) has been regularly performed. Presented symptoms, laboratory and imaging findings meet the criteria of ROHHAD syndrome. 
Conclusions: ROHHAD syndrome should be taken under consideration as a differential diagnosis in obese children. Patients with ROHHAD, with variety of symptoms and possible complications, require regular multidisciplinary follow-up.

\section{P22}

\section{Zachowania sedenteryjne a profil lipidowy dzieci i młodzieży z cukrzycą typu 1}

\section{Sedentary behavior and lipid profile of children and adolescents with type 1 diabetes}

Ewelina Czenczek-Lewandowska ${ }^{1}$, Aneta Weres ${ }^{1}$, Joanna Baran ${ }^{1}$, Justyna Leszczak ${ }^{1}$, Artur Mazur ${ }^{2}$

${ }^{1}$ Instytut Fizjoterapii, Wydział Medyczny, Uniwersytet Rzeszowski ${ }^{2}$ Instytut Pielęgniarstwa i Nauk o Zdrowiu, Wydział Medyczny, Uniwersytet Rzeszowski

Wstęp: Aktywność fizyczna oraz ograniczenie tzw. spoczynkowego trybu życia są ważnymi elementami leczenia cukrzycy typu 1. Regularny wysiłek fizyczny pozwala osiągnąć wiele korzyści zdrowotnych, w tym m.in. poprawia kontrolę metaboliczną przy jednoczesnym obniżeniu ryzyka powikłań choroby. Zachowania sedenteryjne nie sprzyjają dobrym efektom prowadzonej terapii, kontroli metabolicznej, utrzymaniu prawidłowej masy ciała, jak również mogą mieć niekorzystny wpływ na profil lipidowy. Celem pracy była ocena zachowań sedenteryjnych dzieci i młodzieży z cukrzycą typu 1 oraz jej współzależności z profilem lipidowym.

Materiał i metody: Do badania zakwalifikowano 192 dzieci i młodzieży z cukrzycą typu $1 \mathrm{w}$ wieku od 7. do 18 . roku życia, w tym 107 dziewcząt (55,7\%) oraz 85 chłopców (44,3\%). Czas spędzony w sposób bierny odczytano $\mathrm{z}$ akcelerometru noszonego przez badanych w ciągu 7 dni na talii bioder. Dane odniesiono do wyników średniej wartości cholesterolu całkowitego (TC), cholesterolu HDL, cholesterolu LDL oraz trójglicerydów (TG), które pochodziły z ostatniego badania laboratoryjnego wykonanego w okresie maksymalnie 6 miesięcy przed przystąpieniem do badania.

Wyniki: Czas sedenteryjny wynosił średnio 3708,98 $\pm 1158,17$ minut i stanowił średnio $70,56 \pm 11,89 \%$ czasu badania. Średni wynik całkowitego czasu przerw sedenteryjnych wynosił w badanej grupie 7326,09 $\pm 1703,24 \mathrm{mi}-$ nut, natomiast średni czas przerw sedenteryjnych w ciągu dnia wynosił 1168,43 $\pm 296,47$ minut. Im dłuższy był czas sedenteryjny, tym wyższa była wartość cholesterolu LDL $(R=0,18, p=0,033)$.

Wnioski: Niska aktywność fizyczna i zachowania sedenteryjne są aktualnym problemem dzieci i młodzieży z cukrzycą typu 1. Sprzyjają one zaburzeniom gospodarki lipidowej, w tym podwyższonemu stężeniu cholesterolu LDL.
Introduction: Physical activity and reduction of sedentary behaviour are the important part of the treatment of type 1 diabetes. Regular physical activity allows to achieve many health benefits, including improving metabolic control and reducing the risk of complications. Sedentary behavior is not conducive to good effects of therapy, metabolic control, maintenance of normal body weight, as well as may has a negative influence on the lipid profile.

Objective: The aim of the study was to assess the sedentary behavior of children and adolescents with type 1 diabetes and the interdependence with the lipid profile.

Material and methods: The study included 192 children and adolescents with type 1 diabetes, aged 7-18, including 107 girls (55.7\%) and 85 boys (44.3\%). Time spent on sedentary behavior was assessed by accelerometer worn by the subjects within 7 days on the waist of the hips. Data were based on the results of the mean total cholesterol (TC), HDL cholesterol, LDL cholesterol and triglycerides (TG) from the last laboratory test performed within a maximum of 6 months prior to the study.

Results: Sedentary time counted $3708.98 \pm 1138.17$ minutes on average and it was on average $70.56 \pm 11.89 \%$ of the study time. The average result of the total period of sedentary breaks in the study group counted 7326.09 $\pm 1703,24$ minutes, while the average time of sedentary breaks during the day was $1168.43 \pm 296.47$ minutes. The correlation of longer the sedentary time and higher value of LDL cholesterol was statistically significant $(R=0.18$, $p=0.033$ ).

Conclusions: Low physical activity and sedentary behavior are the current problem of children and adolescents with type 1 diabetes. They contribute to disorders of lipid profile, including higher rates of LDL cholesterol.

\section{P23 \\ Rola kategorii masy ciała w powstawaniu wad postawy u dzieci w wieku szkolnym}

The role of the body mass category in the creation of the faulty postures among children in school age

Wojciech Rusek ${ }^{1,2,3}$, Justyna Leszczak ${ }^{1,2}$, Joanna Baran ${ }^{1,2}$, Marzena Adamczyk ${ }^{2,3}$, Aneta Weres ${ }^{1}$, Rafał Baran ${ }^{1,2}$, Grzegorz Inglot ${ }^{4}$, Sławomir Porada ${ }^{5}$,

Ewelina Czenczek-Lewandowska ${ }^{1}$, Teresa Pop ${ }^{1}$

${ }^{1}$ Wydział Medyczny, Uniwersytet Rzeszowski, Rzeszów ${ }^{2}$ Centrum Rehabilitacji REHAMED-CENTER, Tajęcina

${ }^{3}$ RehaKlinika, Polska

${ }^{4}$ Kliniczny Szpital Wojewódzki nr 2 im. Św. Jadwigi Królowej

w Rzeszowie

5Urząd Gminy w Trzebownisku, Rzeszów

Wstęp: W ostatnich latach odsetek dzieci i młodzieży $\mathrm{z}$ nadmierną masą ciała ma tendencję wzrostową. Nadwaga i otyłość w znacznym stopniu powodują zaburzenia 
w postawie ciała, w stanie zdrowia, jak i w gospodarce wodno-elektrolitowej. Celem badań była ocena zależności między wskaźnikiem BMI a występowaniem błędów/ wad w obrębie tułowia.

Materiał i metody: Do badania zakwalifikowano grupę 464 dzieci w wieku od 6 do 16 lat (234 chłopców i 230 dziewcząt). Badania przeprowadzono w Szkołach Podstawowych i Gimnazjach w gminie Trzebownisko. Badanie postawy ciała przeprowadzono za pomocą systemu Zebris. Wysokość ciała mierzono z dokładnością do 0,1 cm za pomocą przenośnego stadiometru PORTSTAND 210. Masę ciała zmierzono analizatorem składu masy ciała firmy Tanita MC - $780 \mathrm{MA} \mathrm{z}$ dokładnością do 0,1 kg. Obliczono wskaźnik masy ciała (BMI).

Wyniki: W obrębie tułowia wykazano istotne statystycznie różnice w przypadku odległości łopatek od płaszczyzny odniesienia oraz położenia barków. Nie zaobserwowano istotności statystycznej w ustawieniu miednicy ( $\mathrm{H}=0,74, p=0,864) \mathrm{w}$ zależności od wskaźnika BMI. Wykazano, że im wyższa masa ciała (wyższy wskaźnik BMI), tym większa odległość łopatek od płaszczyzny czołowej $(\mathrm{H}=11,47, p=0,009)$. Wykazano również, że im większa masa ciała (wyższy wskaźnik BMI), tym wyżej ułożony lewy bark $(\mathrm{H}=8,07, p=0,045)$.

Wnioski: Występowanie wad postawy u dzieci miało związek z kategorią masy ciała dzieci. Nadwaga i otyłość stanowiły czynnik sprzyjający asymetrii położenia barków i łopatek. Brak redukcji nadmiernej masy ciała może w przyszłości mieć wpływ na pogłębienie wady.

Introduction: In the last few years the number of children and teenagers with the excessive body mass has a growing tendency. Overweight and obesity to the large extend cause the disorders in the body posture, in the health state and in the water and electrolyte balance. The aim of the study was the assessment of the occurrence of the correlation between BMI index and the occurrence of the mistakes/faults of the chosen parameters in the trunk area.

Objective: The aim of the studies was to assess the occurrence of correlation between BMI index and the occurrence of the mistakes/faults of the chosen parameters in the trunk area.

Material and methods: The group of 464 children in the age from 6 to 16 years ( 234 boys and 230 girls) was qualified to the study. The study was conducted in Primary Schools and Grammar Schools in Trzebownisko region. The study of the body posture was conducted with the use of Zebris system. The body height was measured with the accuracy up to $0,1 \mathrm{~cm}$ with the use of the portable stadiometer PORTSTAND 210. The body mass was measured by the body mass analyser Tanita MC - 780 MA with the accuracy up to $0,1 \mathrm{~kg}$. The body mass index (BMI) was calculated.
Results: In the trunk area, the statistically significant differences were indicated in the case of the distance of the scapulae from the corresponding plane and the shoulder position. The statistical significance was not observed in the position of the pelvis $(\mathrm{H}=0.74, p=0.864)$, and the BMI index. It was indicated, that the higher the body mass is, the bigger distance of the scapulae from the frontal plane there is $(\mathrm{H}=11.47, p=0.009)$. Additionally, it was indicated, that the bigger the body mass is (higher $\mathrm{BMI}$ index) the higher position of the left shoulder is observed $(\mathrm{H}=8.07, p=0.045)$.

Conclusions: The occurrence of the faulty postures in children has a connection with the body mass category in children. Overweight and obesity constituted a factor fostering the asymmetric position of the shoulders and scapulae. The lack of excessive body mass reduction can influence the worsening of faulty posture in the future.

\section{P24}

\section{Stan odżywienia grupy dzieci z Krakowa i okolic w odniesieniu do funkcjonujących kryteriów oceny}

Nutritional status of group of children from Krakow and its surroundings in relation to the existing assessment criteria

Beata Piórecka ${ }^{1}$, Agnieszka Kozioł-Kozakowska², Paweł Jagielski ${ }^{1}$, Agnieszka Suder ${ }^{3}$

'Zakład Żywienia Człowieka, Instytut Zdrowia Publicznego, Wydział Nauk o Zdrowiu, Uniwersytet Jagielloński Collegium Medicum 2Pracownia Dietetyki Pediatrycznej, Klinika Pediatrii, Gastroenterologii i Żywienia, Wydział Lekarski, Uniwersytet Jagielloński Collegium Medicum

${ }^{3}$ Zakład Anatomii, Katedra Fizjoterapii, Wydział Rehabilitacji Ruchowej, Akademia Wychowania Fizycznego w Krakowie

Wstęp: Ocena rozwoju somatycznego dzieci i młodzieży jest trudna ze względu na funkcjonujące różne biologiczne układy odniesienia. Określenie występowania nadwagi lub otyłości wyłącznie na postawie oceny BMI jest obarczone błędem. Celem pracy jest przedstawienie wyników oceny stanu odżywienia grupy dzieci w zależności od przyjętej interpretacji.

Materiał i metody: Badanie zostało przeprowadzone w okresie marzec/czerwiec 2018 r. wśród 332 zdrowych uczniów szkół podstawowych (187 chłopców, 145 dziewczą) $\mathrm{z}$ terenu miasta i gminy Niepołomice oraz Krakowa, których rodzice wyrazili pisemną zgodę na udział dziecka w badaniu. Przeprowadzono pomiary antropometryczne oraz dokonano oceny zawartości tkanki tłuszczowej wśród dzieci metodą bioimpedancji (Tanita BC-418). Do oceny stanu odżywienia zastosowano interpretacje BMI oraz BMI $-z$ score (BMI- $z$ ) w odniesieniu do siatek centylowych 
OLAF, a także sprawdzono odsetek należnej masy ciała do wzrostu oraz określono procentową zawartość tkanki tłuszczowej (\%BF) według wytycznych międzynarodowych (McCarthy i wsp., 2006). Analizy statystyczne w podziale według płci oraz interpretacji stanu odżywienia przeprowadzono w programie IBM SPSS Statistics 25.

Wyniki: Średnia wieku ogółu badanych wyniosła $10,36 \pm 1,64$ roku i nie różniła się w zależności od płci. Wartość średnia procentowej zawartości tkanki tłuszczowej wśród chłopców wyniosła 20,81 \pm 5,56 oraz 23,50 $\pm 4,84$ dla dziewcząt. W interpretacji stanu odżywienia z wykorzystaniem BMI, BMI- $z$ oraz należnej masy ciała do wzrostu nie występowały różnice statystyczne zależne od płci, natomiast wystąpiła różnica w ocenie \%BF $(p=0,001)$, gdzie nadmiar tkanki tłuszczowej istotnie częściej dotyczył chłopców (nadwaga 19,6\%, otyłość 14,1\%) niż dziewcząt (nadwaga 10,6\%, otyłość 5\%). W przypadku zastosowania procentu należnej masy ciała do wzrostu częściej określano dla ogółu badanych otyłość (15,9\%), $\mathrm{w}$ porównaniu $\mathrm{z}$ pozostałymi kryteriami oceny, gdzie odpowiednio otyłych było wg BMI- $z-3 \%$, BMI - 6,7\% oraz \%BF - 10,2\% dzieci. Największa zgodność określenia prawidłowej masy ciała $(90,5 \%)$ dotyczyła wyników stanu odżywienia dzieci przy uwzględnieniu procentu należnej masy ciała do wzrostu oraz interpretacji BMI.

Wnioski: Określenie nadmiaru masy ciała w grupie badanych dzieci jest zróżnicowane w zależności od przyjętego kryterium. Brakuje wyników badań populacyjnych zawartości tkanki tłuszczowej wśród dzieci i młodzieży w Polsce, co utrudnia rozpoznanie nadwagi lub otyłości z wykorzystaniem BMI.

Introduction: Assessment of somatic development in children and adolescents is difficult due to different biological reference systems. The determination of overweight or obesity based only on BMI assessment is burdened with an error.

Objective: The aim of the study is to present the results of the assessment of nutritional status of a group of children depending on interpretation criteria.

Material and methods: The survey was conducted in the period of March/June 2018 year in group of 332 healthy primary school students (187 boys, 145 girls) from the Niepołomice and Krakow community, whose parents gave their written consent to participate in the survey. Anthropometric measurements were performed and the fatty tissue content in children was estimated using the bioimpedance method (Tanita BC-418). To assess nutritional status, BMI and BMI $z$-score (BMI- $z$ ) interpretations by OLAF percentiles charts were used, as well as the percentage of body weight to height and the body fat content (\%BF) according to international guidelines (McCarthy et al., 2006) were checked. Statistical analyses by gender and interpretation of nutritional status were conducted in the IBM SPSS Statistics 25 programme.

Results: The average age of the respondents was 10.36 \pm 1.64 and did not statistical difference according to gender. The average fat percentage among boys was $20.81 \pm$ 5.56 and $23.50 \pm 4.84$ for girls. In the interpretation of nutritional status using BMI, BMI- $z$ and percentage of body weight for growth there were no statistical differences depending on sex, but we observed difference in the assessment of $\% \mathrm{BF}(p=0.001)$, where excess body fat was significantly more common in boys (overweight $19.6 \%$, obesity $14.1 \%$ ) than girls (overweight $10.6 \%$, obesity $5.0 \%$ ). In the case of using percentage of body weight for height, obesity was more frequently determined for the whole group (15.9\%), in comparison with the other evaluation criteria, where obesity was according to BMI $z-3 \%$, BMI $-6.7 \%$ and $\%$ BF for $10.2 \%$ of children, respectively. The highest compatibility of the nutritional status results was for percentage proper body weight for height $(90.5 \%)$ and BMI interpretation.

Conclusions: The determination of excess body weight in studied group of children varies depending on the adopted criteria. The results of population studies of fat tissue content in children and adolescents in Poland are missing, making difficulties in proper diagnosis of overweight or obesity using BMI.

\section{P25 \\ Ocena stanu odżywienia i wiedzy nastolatków z Poznania na temat prawidłowego odżywiania się - doniesienia wstępne}

\section{Evaluation of the nutritional status and knowledge about proper nutrition of adolescents from Poznan - preliminary reports}

Michalina Nawrot ${ }^{1}$, Izabela Kwiatkowska ${ }^{1}$, Ewelina Wierzejska²

'Studenckie Towarzystwo Naukowe, Uniwersytet Medyczny im. Karola Marcinkowskiego w Poznaniu

${ }^{2}$ Katedra i Zakład Profilaktyki Zdrowotnej, Uniwersytet Medyczny im. Karola Marcinkowskiego w Poznaniu

Wstęp: Wraz z rozwojem mediów, nowych technologii oraz internetu nastąpiło zwiększenie występowania otyłości oraz innych chorób cywilizacyjnych wśród Polaków. Trend ten zauważalny jest nie tylko wśród osób dorosłych, lecz także dzieci i młodzieży, co jest wysoce niepokojącym zjawiskiem. Otyłość w młodym wieku jest czynnikiem ryzyka rozwoju wielu schorzeń, także chorób metabolicznych. 
Cel badania: Celem badania było określenie stanu odżywienia i wiedzy nastolatków z Poznania na temat prawidłowego odżywiania się.

Materiał i metody: Badania przeprowadzono w formie metryczki oraz wybranych pytań ze standaryzowanej ankiety KomPan „Kwestionariusz do badań poglądów i zwyczajów żywieniowych dla osób w wieku od 16 do 65 lat". Ze względu na wiek badanych do oceny stanu odżywienia posłużył wskaźnik masy ciała (body mass index - BMI). Dotychczas przeprowadzono 107 ankiet wśród uczniów klas 1-3 poznańskich liceów.

Wyniki: Wskaźnik masy ciała u 77\% ankietowanych mieścił się w zakresie zalecanych norm (18,5-24,99 kg/ $\mathrm{m}^{2}$ ), jego średnia wyniosła $21,05 \pm 2,60 \mathrm{~kg} / \mathrm{m}^{2}$. Większość młodzieży deklarowało podjadanie przekąsek więcej niż raz dziennie. Uczniowie mieli znaczne trudności ze wskazaniem produktów o dużej gęstości odżywczej oraz różnicowaniem produktów zawierających cukry proste. Swoją wiedzę na temat zdrowego odżywiania 19\% uczniów określiło jako niedostateczną, 40\% jako dostateczną, 41\% jako dobrą. Żadna z osób ankietowanych nie stwierdziła, że jej wiedza na temat poprawnego odżywiania jest bardzo dobra.

Wnioski: Wstępne wyniki ukazują znaczne braki w wiedzy na temat zdrowego odżywiania się poznańskiej młodzieży. Konieczne jest zaplanowanie szeroko pojętej edukacji żywieniowej oraz przeprowadzenie dokładniejszych badań wśród większej liczby młodzieży.

Introduction: The development of media, new technologies and the Internet has contributed to the growing prevalence of obesity and other civilization diseases among Poles. This trend is noticeable not only among adults, but also children and adolescents, which is highly disturbing. Obesity at an early age is a risk factor for the development of many affection, such as metabolic diseases.

Objective: The aim of the study was to determine the nutrition status and knowledge about proper nutrition of adolescents from Poznań.

Material and methods: The research was carried out in the form of selected questions from the standardized survey KomPan "Kwestionariusz do badań poglądów i zwyczajów żywieniowych dla osób w wieku od 16 do 65 lat". Due to the age of the subjects, BMI (body mass index) was used to assess the nutritional status. Until now, 107 surveys were carried out among the students of classes 1-3 of Poznan's high schools.

Results: In $77 \%$ of respondents BMI was within the recommended range $\left(18.5-24.99 \mathrm{~kg} / \mathrm{m}^{2}\right)$, its average was $21.05 \pm 2.60 \mathrm{~kg} / \mathrm{m}^{2}$. Most of the youth declared eating snacks more than once a day. The students had considerable difficulty in identifying products with high nutritional density and differentiation of products containing simple sugars. $19 \%$ of students described their knowledge about proper diet as insufficient, $40 \%$ as satisfactory, $41 \%$ as good. None of the respondents stated that her knowledge about proper nutrition is very good.

Conclusions: Results indicate significant deficiencies in knowledge about healthy eating of young people in Poznań. It is necessary to carry out more detailed research and plan solid nutritional education.

\section{P26 \\ Ocena składu masy ciała i wartości ciśnienia tętniczego u 8-letnich dzieci uczestniczących w programie zdrowotnym w mieście Szczecinie}

\section{Assessment of body mass composition and blood pressure values in 8-year-old children participating in the health program in the city of Szczecin}

Marta Demiaszkiewicz, Dominika Raducha, Joanna Ratajczak, Irmina Gapińska,

Klaudia Bartoszewicz, Tomasz Jackowski, Teresa Adamczyk, Katarzyna Marcinkiewicz, Agnieszka Boczysko-Mokosa, Justyna Szmit-Domagalska, Anita Horodnicka-Józwa, Elżbieta Petriczko, Mieczysław Walczak

Klinika Pediatrii, Endokrynologii, Diabetologii, Chorób Metabolicznych i Kardiologii Wieku Rozwojowego, Pomorski Uniwersytet Medyczny w Szczecinie

Wstęp: Celem pracy była ocena składu masy ciała oraz ciśnienia tętniczego w populacji 8-letnich dzieci $\mathrm{z}$ nadmiarem masy ciała (BMI > $90 \mathrm{c}$ ) przed i po rocznej interwencji specjalistycznej.

Materiał i metody: Badaniami objęto grupę 560 8-letnich dzieci - średnia wieku $8,47 \pm 0,8$ roku - z miasta Szczecina (258 chłopców i 302 dziewczynki), z czego 86 ukończyło roczny program interwencyjny (cztery wizyty z poradami specjalistów: lekarza, dietetyka, specjalisty aktywności fizycznej i psychologa). U każdego dziecka wykonano pomiary antropometryczne, badanie składu masy ciała metodą bioimpedancji elektrycznej i pomiary ciśnienia tętniczego (uśrednione trzykrotne pomiary aparatem Omron).

Wyniki: W całej badanej grupie $(n=560)$ nadwagę stwierdzono u 63,21\% dzieci, otyłość u 36,79\%. Podwyższone ciśnienie tętnicze stwierdzono u 18,57\% dzieci. Średnie BMI dzieci podczas pierwszej wizyty w programie wyniosło 22,45 $\pm 2,68$, średni centyl BMI 94,58 \pm 3,72 . Analiza składu masy ciała wykazała średni procent tkanki tłuszczowej 23,38 \pm 5,31\% (20,19\% u chłopców i $26,14 \%$ u dziewczynek), masę tkanki tłuszczowej 10,19 $\pm 3,91 \mathrm{~kg}(9,39 \mathrm{~kg}$ u chłopców i 10,87 kg u dziewczynek), masę tkanki mięśniowej 29,98 \pm 5,38 kg (32,69 kg u chłopców i 27,64 kg u dziewczynek), beztłuszczową 
masę ciała 32,24 \pm 6,07 kg (35,04 kg u chłopców i 29,82 kg u dziewczynek), zawartość wody 23,43 $\pm 4,26 \mathrm{~kg}(25,41 \mathrm{~kg}$ u chłopców i $21,72 \mathrm{~kg}$ u dziewczynek). W wyniku rocznej interwencji specjalistycznej BMI badanych dzieci wzrosło średnio o $0,55 \pm 1,15$ (jednak istotnie statystycznie tylko $\mathrm{w}$ grupie dzieci $\mathrm{z}$ nadwagą), ale centyl BMI obniżył się średnio o $1,21 \pm 2,34$. Średnie ciśnienie tętnicze i centyl ciśnienia tętniczego nie zmienił się istotnie statystycznie. Wszystkie parametry w składzie masy ciała wzrosły istotnie statystycznie, jednak zdecydowanie większy był przyrost tkanki mięśniowej w stosunku do tkanki tłuszczowej. Średni przyrost masy tkanki mięśniowej wyniósł 3,23 \pm $1,35 \mathrm{~kg}$, beztłuszczowej masy ciała $3,11 \pm 3,51 \mathrm{~kg}$, tkanki tłuszczowej $1,71 \pm 2,11 \mathrm{~kg}$, procentowa zawartość tkanki tłuszczowej wzrosła średnio o 0,81 $\pm 3,00 \%$, a zawartość wody średnio o 2,39 $\pm 1,12 \mathrm{~kg}$.

Wnioski: Wielodyscyplinarne programy interwencyjne dla dzieci z nadmiarem masy ciała mają wymierny efekt w postaci spadku centyla BMI oraz pożądanych zmian składu masy ciała, szczególnie w grupie dzieci z otyłością. Dodatkowo mają niewymierny efekt edukacyjny dla dzieci i ich rodzin w postaci propagowania i utrwalania zmiany stylu życia.

Objective: The study assess body mass composition and blood pressure in 8-year-old children population with excessive body weight $\left(\mathrm{BMI}>90^{\text {th }}\right.$ percentile) before and after one-year specialist intervention.

Material and methods: There were 560 participant at the average age of $8.47 \pm 0.8$ years, from Szczecin (258 boys and 302 girls), 86 children completed an annual intervention program (four visits with specialist: medical doctor, dietitian, specialist in physical activity and psychologist). Anthropometric measurements, body composition by BIA and blood pressure measurements were performed.

Results: In study group $(n=560), 63.21 \%$ children were overweight, and $36.79 \%$ obese. Elevated blood pressure was found in $18.57 \%$ of children. The average BMI during the first visit was $22.45 \pm 2.68$, percentile of BMI: $94.58 \pm 3.72$. The analysis of body mass composition showed an average body fat percentage $23.38 \pm 5.31 \%$ (20.19\% in boys and $26.14 \%$ in girls), fat mass $10.19 \pm$ $3.91 \mathrm{~kg}(9.39 \mathrm{~kg}$ in boys and $10.87 \mathrm{~kg}$ in girls), muscle mass $29.98 \pm 5.38 \mathrm{~kg}(32.69 \mathrm{~kg}$ in boys and $27.64 \mathrm{~kg}$ in girls), lean body mass $32.24 \pm 6.07 \mathrm{~kg}$ ( $35.04 \mathrm{~kg}$ in boys and $29.82 \mathrm{~kg}$ in girls), water content $23.43 \pm 4.26 \mathrm{~kg}(25.4$ $\mathrm{kg}$ in boys and $21.72 \mathrm{~kg}$ in girls). After annual specialist intervention BMI increased on average by $0.55 \pm 1.15$ (however, statistically significant only in the group of overweight children), but BMI percentile decreased on average by $1.21 \pm 2.34$. Blood pressure and it's percentile did not change significantly. All parameters in body composition increased statistically significantly, however, the increase in muscle tissue was greater than adipose tissue. The increase of fat mass was on average $3.23 \pm 1.35 \mathrm{~kg}$, lean body mass $3.11 \pm 3.51 \mathrm{~kg}$, adipose tissue $1.71 \pm 2.11 \mathrm{~kg}$, percentage of adipose tissue $0.81 \pm 3.00 \%$, water content $2.39 \pm 1.12 \mathrm{~kg}$.

Conclusions: Multidisciplinary intervention programs for children with excess body mass have a measurable effect as a decrease in BMI percentile as well as expected changes in weight composition, especially in the group of children with obesity. In addition, they have an immeasurable educational effect for children and their families as promoting lifestyle changes. 